(4.)

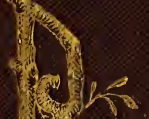

in $\sqrt{3})^{2}$

- 191,00
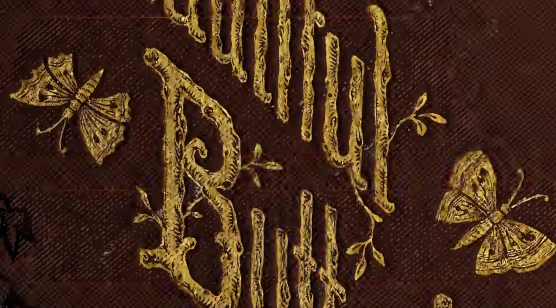

(1) 190

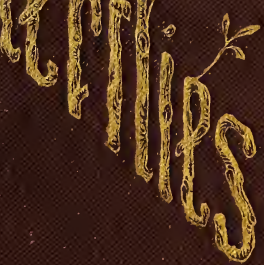

HG. ADAMS. 


\section{Library \\ of the}

University of Toronto 
AParry Giprow 10 Cotober 1883 

BEAUTIFUL BUTTERFLIES. 

Digitized by the Internet Archive in 2017 with funding from University of Toronto 

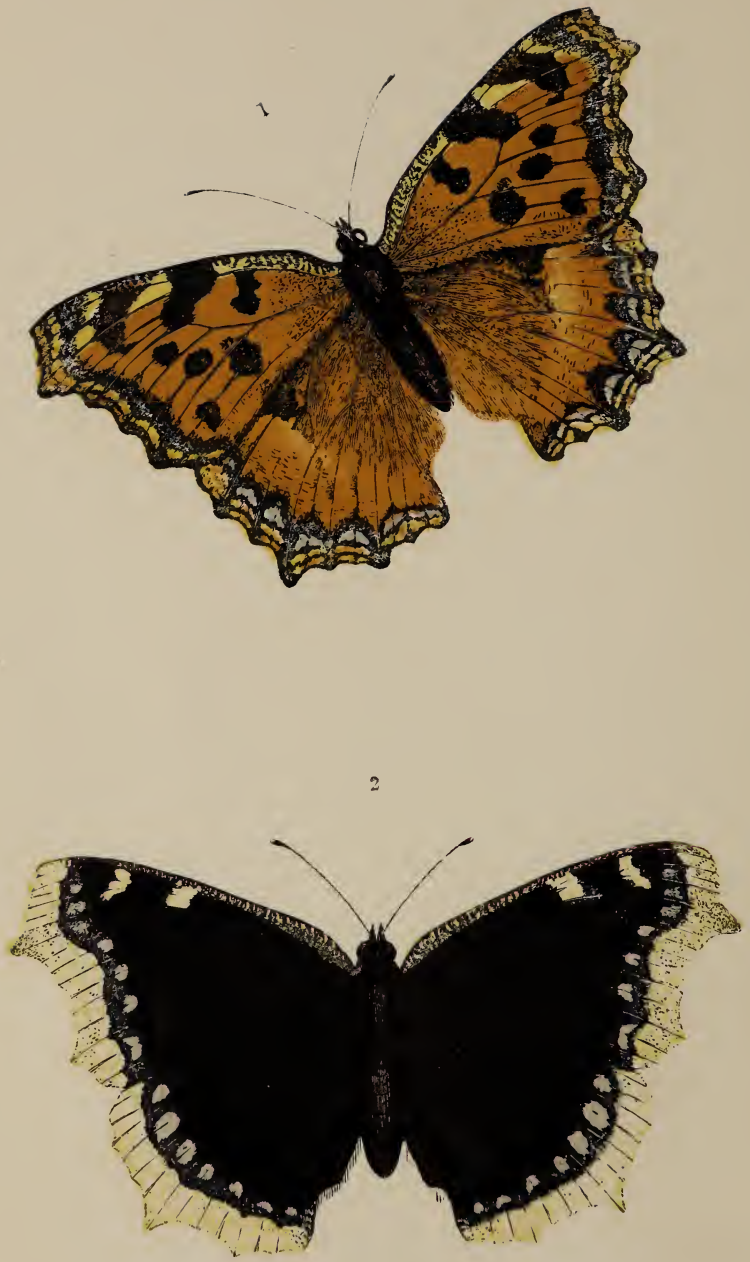

1. Large Tortoise-.shell. 2. Camberwe!l Beauty. 


\section{BEAUTIFUL BUTTERFLIES}

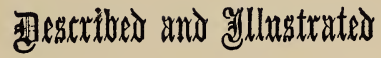

\section{WITH THE \\ HISTORY OF A BUTTERFLY}

THROUGH ALL ITS CHANGES AND TRANSFORMATIONS;

AND AN EXPLANATION OF THE

Srientific Cerms used by a daturalists in refrxence theretr.

\section{By H. G. ADAM S,}

AUTHOR OF 'NESTS AND EgGS OF FAMILIAR BIRDS,' 'FAVORITE SONG BIRDS;

'BEAUTIFUL SHELLS,' 'HUMMING BIRDS,' ETC. HTC.

ILLUSTRATED WITH EIGHT COLOURED PLATES AND NUMEROUS WOOD ENGRAVINGS.

LONDON :

GROOMBRIDGE AND SONS, 5, PATERNOSTER ROW. 
PRINTED BY J. E. ADLARD,

BARTHOLOMEW CLOSE. 


\section{O N TENTS.}

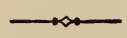

PAGE

\section{INTRODUCTION}

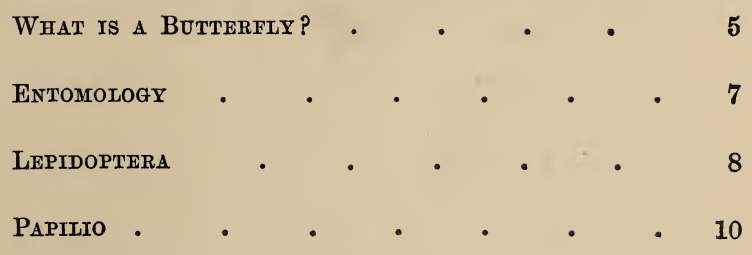

HISTORY OF THE BUTTERELY 
DESCRIPTION OF SPECIES .

SWALLOW-TaIL

MARBLed White

Scotch Argus

White AdmiraL

Red Admiral

Peacock Butterfit

Large TortoIse-SHeLL

SMaLl ToRTOISE-ShelL

Camberwell Beauty

Comma Butterfly

Painted Lady

Scarce Painted Lady .

Purple Emperor

Brown Hairstreak

Greasy Fritillaky

Glanville Fritillaki .

Peart-bordered Fritictary 
DESCRIPTION OF SPECIES (continued)

High Brown Fritillart • • . . 113

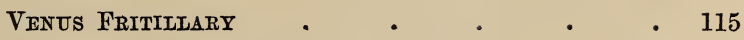

LARGE COPPER $\quad$ - . $\quad$ - $\quad$ - $\quad 117$

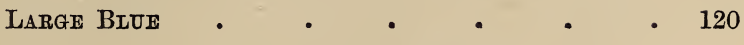

LIST OF SPECIES $\quad$ - $\quad$ - $\quad$ - $\quad$ - $\quad 125$

INDEX OF SPECIES • $~+\quad$ • $\quad$ • 135 



\section{BEAUTIFUL BUTTERFLIES.}

\section{INTR ODUCTION.}

"Lo! the bright train their radiant wings unfold, With silver fringed, and freckled o'er with gold;

On the gay bosom of some fragrant flower They, idly fluttering, live their little hour, Their life all pleasure, and their task all play, All spring their age, and surshine all their day."

Mrs. Barbauld.

"W" HAT a pleasant life that must be to lead!" methinks I hear my young readers exclaim; "who would not join in the song,-

' I'd be a butterfly, born in a bower, Where roses, and lilies, and violets meet?'

No tiresome books to bother the brains; no fagging at lessons then; no cross looks, no angry words ; no headaches, no stomach-aches, no whippings, no brimstone and treacle; no anything but what is delightful and pleasant; flitting about in the sunshine all day long. 
and rocked to sleep at night in a lily bell, or some other such agreeable resting-place; sipping the sweet juices out of the flowers, and sporting in the air with companions that never get out of temper, and quarrel. Oh, that would be delightful! Yes, I'd be a Butterfly! Would not you ?"

My dear young Master, or Miss, as the case may be, most assuredly I would not be a Butterfly. Nay, do not look so incredulous, but listen, and I will tell you why. In the first place I have no fancy to be snapped up by a winged monster two or three hundred times bigger than myself, as yon bright-winged flutterer has just been by the Swallow, that has a little hungry family up in the chimney there, and must find Butterflies or some other equally gay and thoughtless creatures wherewith to satisfy their wants. In the next place, I should not like to undergo such a series of changes and transformations as the Butterfly does, before he comes out in his beautiful silken dress, to live his little life of a few hours in the sunshine; and for all that is said in praise of "a short life and a merry one," by the thoughtless and careless among mankind, yet would I rather, if it so pleased God, live a long life, that I might have time to cultivate and exercise these high and noble faculties of the mind, which distinguish man from the rest of creation, and so exercise them as at once to glorify my Maker, and benefit my 
fellow-creatures. Nay, nay, my young friends, do not wish to be a Butterfly, nor any other merely soulless thing; you have within you an immortal principle-

"A vital spark of heavenly flame,"

as the poet has finely termed the soul, which the Butterfly has not; which the most sagacious and long-lived of animals has not; for the salvation of this soul of yours a great price has been paid, a tremendous sacrifice offered, and young as you may be, I would have you think seriously of this. You are not a Butterfly, thank God that you are not! Never wish to be one! Do not lead a Butterfly kind of life, as too many do, flitting and fluttering, and sporting away the precious time given you for other purposes. Be diligent, be useful. Headaches and heart-aches, too, you must have, and many hard lessons you must learn, even when your schooldays are over; for it is ordered by an all-wise Providence, that the human soul shall be purified by trouble and affliction, and so prepared for the better land towards which we are all journeying. The end of the Butterfly is here; your end is in eternity. Think of that, and think, too, of the many pleasures which you enjoy, of which the Butterfly can know nothing; intellectual pleasures-pleasures of thought and feeling; warm affections and lively hopes are yours, out-gushing from your own heart and bosom, and from the hearts and 
bosoms of those to whom you are dear, and watching round you like angels wherever you move. You can speak, and write, and think, and above all you can pray, and be prayed for. Here is a privilege! For the poor soulless Butterfly there are none of these good things.-

" Its little hour of sunshine o'er,

It passes from the view,

To breathe the breath of life no more-

It is not so with you.

Your soul shall from the tomb arise

In beautiful array,

To dwell for aye in Paradise,

And everlasting day." 


\section{WHAT IS A BUTTERFLY?}

ss Who can follow Nature's pencil here?

Their wings with azure green and purple glossed, Studded with coloured eyes, with gems embossed; Inlaid with pearl, and marked with various stains Of lively crimson through their dusky veins."

Mrs. Barbatld.

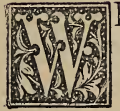

HAT is a Butterfly?-An insect. True; and the name we are told is a literal translation of the old Saxon word Buttor-fleoze, applied to those silken-winged flies, because they usually become plentiful in the butter season. I have next to ask you what you understand by an Insect?-A little crawling, or flying thing, with — Nay, that will not do at all. Let us find out Johnson's definition of the word. Ah, here it is, in Latin Insectum, that which is cut-" Insects may be considered together as one great tribe of animals : they are called Insects from a separation in the middle of their bodies, whereby they are cut into two parts, which are joined together by a small ligature, as we see in wasps and common flies." You have no doubt noticed this remarkable peculiarity of the Insects here named; it is especially conspicuous in the wasp, the lower part of whose yellow body looks as 
if it would drop off at every motion. We have heard a very slim and genteel lady spoken of as having a waist like a wasp, but hope she was not waspish in other respects. Another meaning for the word insect, given by the great dictionary-maker, is "Anything small or contemptible." Let us illustrate this meaning. — "Sir," said a little upstart man, desirous of impressing the person he addressed with a due sense of his consequence, "do you know what sect I belong to?" "I should say, by the look of you," was the goodhumoured, yet cutting reply, "to that called Insect."

We must not, however, consider that because things or persons are small, that they are therefore mean and contemptible; arrogance and undue assumption of importance always make people so; but in the world of Nature we find so much that is wonderful in design, and beautiful in construction, in the minutest creatures, that to the philosophic mind they can never be so. With the poet Cowper,-

"In the vast and in the minute we see The unambiguous footsteps of the God Who gives its lustre to the insect's wing, And wheels His throne upon the rolling worlds."

I am now going to introduce to you another member of the learned family of OLogies. In a former volume of this series you made the acquaintance of two or 


\section{Beautiful Butterfies.}

three members of this family.* This is rather a tall individual.-What do you think of him?

\section{ENTOMOLOGY.}

Five syllables, thus-En-to-mol-o-gy. Let us see what account Dr. Johnson gives of him. None at all! Not in the big folio? Nay; then he must have sprung into existence since the great lexicographer's time; for all that he stands upon Greek legs-entom, an insect; and logos, a discourse. Now you know what it means literally - a discourse on an insect, or as generally applied, "That part of ZooLogr, or Natural History, which treats of Insects." By this science we are conducted into the most extensive and populous province in the whole empire of nature, and shown a greater diversity of form and colouring, and more surprising adaptations of means, than is presented to us by any other branch of physical science. Truly has it been said that "Entomology claims it as its right to demonstrate the existence and perfections of that Almighty Power which produced and governs the universe. It is one chapter in the history of creation, and naturally leads every intelligent mind to the Creator; for there are no proofs of His existence more level to the appre- 
hension of all than those which this chapter offers to the understanding."

"In an insect or a flower,

Such microscopic proofs of skill and power

As hid from ages past God now displays,"

says the poet Southey, in allusion to the wonders revealed by the microscope in the natural world, and especially in that branch of it with which Entomology has to do.

But it is to one particular division of the insect tribes that $I$ have now to direct the attention of my readers.

\section{LEPIDOPTERA}

is the name given to that order of insects in which "Beautiful Butterflies" are included. Here is another long word not to be found in Johnson's dictionaryLep-i-dop-te-ra, five syllables, derived from two Greek words-lepis, a scale; and pteron, a wing. Butterflies and Moths, then, are Lepidopterous or scaly-winged insects; if you observe one of thern closely, you will find that the wings are covered with a fine downy substance like meal. Examined under a microscope this will be found to consist of minute scales of uniform size and shape, that is, upon one species of fly, for they 
differ considerably in this respect in different species, as the following drawings will show.

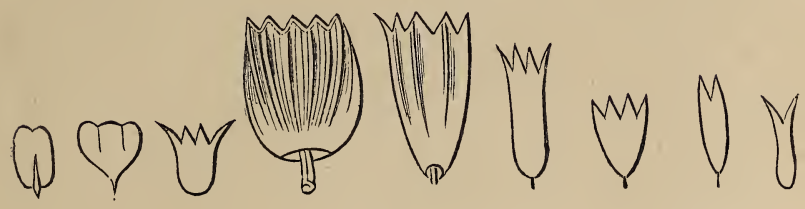

They are fixed to the wing by means of a fine pedicle, or stalk, similar to that of a plant, only so small as not to be seen by the naked eye. It is in these scales that the beautiful colours, which make the wings look like painted velvet, exist; if you rub them off, nothing but a thin transparent membrane remains; this is veined all over, much like the skeleton leaves which you may have seen, and these veins no doubt answer the double purpose of canals for conveying nourishment to the frame, and of ribs for giving it mechanical strength. A naturalist named Leiuwenhoek has counted as many as four hundred thousand scales upon the wings of the Silk Moth, and some of our British Butterflies are four times as large as this; there are foreign Moths which sometimes measure nearly a foot across the wings: think of the number of scales required to cover them. It has been said that "a modern Mosaic picture may contain eight hundred and seventy Tesserulæ, or separate pieces, in one square inch of surface; but the same 


\section{Beautiful Butterfies.}

extent of a Butterfly's wing may sometimes consist of no fewer than one hundred thousand, seven hundred and thirty-six: he would be a rich man indeed who had as many guineas. How long would it take him to count them, suppose he were to pick them up sixty a minute, and work ten hours a day at that rate? There's an exercise in mental arithmetic for you.

Now let us go back to our subject, which you know is Lepidopterous Insects-recollect that long word-or Butterflies, we were going to say, but the thought occurred that all these scaly-winged insects are not Butterflies; some of them are Moths, and some Hawk Moths. The three great divisions into which naturalists have divided this order of insects are, as you must try and remember, first, Butterflies, or Diurnal, that is, Day, Lepidoptera; second, Moths, or Nocturnal, that is, Night, Lepidoptera ; and third, Hawk Moths, or Crepuscular, that is, Twilight, Lepidoptera; these names indicate their different seasons of flight. It is with the first division only that we have to do at present; and this forming a genus of itself, is distinguished by a generic name, and here it is-

\section{PAPILIO.}

Look at it well, now, so that you may know it again when you see it, as you often will in books of Natural 
History. Pa-pil-io, pronounced pa-pil-yo; it comes from the Latin, and means a Butterfly, which is all I can tell you about it. In botanical works you will sometimes see plants spoken of that have papitionaceous flowers, that is, with petals something in shape like the wings of a Butterfly, as the sweet pea has, and several other beautiful ornaments of the garden, with which you must be familiar. This resemblance of the bright-hued flowers to the Butterflies' wings have been often alluded to by the poets, one of whom, named Thomas Moore, describes

\footnotetext{
"A child at play,

Among the rosy wild flowers singing,

As rosy and as wild as they,

Chasing with eager hands and eyes

The beautiful blue Butterfles

That fluttered round the jasmine stems,

Like winged flowers or flying gems."
}

In another part of the same poem, which is called "Lalla Rookh," the name of an Eastern princess, we find a scene described in which

"Sparkle such rainbow Butterflies,

That one might fancy the rich flowers

That round them in the sun lay sighing,

Had been by magic all set flying."

But let us get on with our lesson. Butterflies, then, we have learned, are a day-flying genus, called Papilio, of the Lepidopterous or mealy-winged order of that 
class of living creatures called Insects, the study of whose nature and habits is termed Entomology. The great Swedish naturalist, Linnæus, arranged all the flying, walking, creeping, and swimming things known in his time into six classes; these classes included several orders; the orders various genera; and the genera distinct species; more or less numerous as the case might be. This was called the Linnæan system of natural history. I need not explain to you the principles on which it was based, nor tell you in what respects it differs from the systems of the illustrious Frenchman Cuvier and other naturalists. One of these days I may perhaps do this, but at present it is scarcely necessary to puzzle your brains about it. I want you clearly to understand what a Butterfly is; to learn one letter of the great alphabet of nature first, and it will assist you in acquiring the rest. Now, what is a Butterfly? "An insect of the Lepidopterous order — " Nay, you are going to tell me what it is called merely; undoubtedly it is all that, but it is also something more-a wonderful manifestation of the wisdom and the goodness of the Almighty Creator, as I am now going to show you. 


\section{HISTORY}

$$
\text { OF }
$$

THE BUTTEFLY。 



\section{HISTORY OF THE BUTTERFLY.}
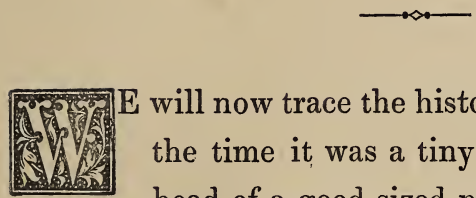

will now trace the history of the butterfly, from the time it was a tiny egg, not so big as the head of a good-sized pin, glued by the mother insect to that particular kind of leaf on which the caterpillar, that it will shortly turn to, feeds. Now, here is a wonder at once; the Butterfly, recollect, does not feed upon leaves, but the sweet juices extracted from flowers and those by no means flowers of the plant from which it derives nourishment while in the caterpillar or larva state, as it is called. How then should it know the particular description of food suitable for its crawling progeny, in every respect so unlike itself? We can only say that God teaches it. Instinct is the name generally given to the mysterious knowledge which seems to direct all the members of the brute creation. Man, you know, has Reason for his guidance, animals have not; still they are guided, and often more surely to the desired end, than man with all his boasted reason The poet Pope has said

"Reason raise o'er Instinct as you can, In this 'tis God directs, in that 'tis man." 
16 Beautiful Butterfies.

Well, then, guided by this mysterious principle called Instinct, the Butterfly affixes its eggs just where the young Caterpillars, when they issue forth, are sure to find plenty of suitable food ready for them.

To the naked eye all Butterflies' eggs look round, and pretty much alike, but by the following representation of those of six different species, magnified, you will see that they are by no means so. You cannot fail to be struck with the beautiful regularity of the shapes and the markings. Do they not seem to say to you-

\section{The hand that made us is Divine!}
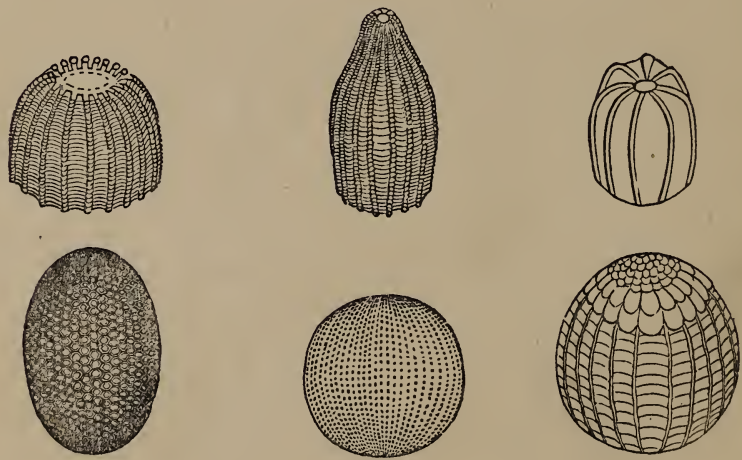

The term Caterpillar is supposed to be derived from two old French words-acat, food or provision, whence comes the term cates, sometimes used by English authors; and piller-to rob or plunder, the origin of the word pillage. There is here an obvious 


\section{Beautiful Butterfies.}

reference to the voracious habits of these creatures, the most destructive of any to vegetation. In Scripture they are spoken of as eating up what the other insect ravagers have left, as you will see by turning to the fourth verse of the first chapter of the prophet Joel. In Hebrew the Caterpillar is called a consumer, and well does the cultivator of the land know it to be such; it begins to eat directly it comes out of the egg, and continues to eat, eat, nothing but eat, except grow, which it does very fast, and crawl from place to place in search of fresh food, of which it sometimes consumes more than double its own weight in twenty-four hours. Think if you were to do this, what bakers', butchers', and grocers' bills your parents would have to pay.

The body of the caterpillar is, as you know, long, and nearly cylindrical, that is, like a tube, or pipe; it is divided throughout into twelve segments, as they are called, that is, divisions, as though pieces of thread were tied round it at equal distances, and drawn sufficiently tight to make slight indentations. The skin, which covers this body, is usually soft and membranous, that is, web-like, covered with little lines, which cross and re-cross each other, as in a piece of network; sometimes, however, it is of a coriaceous texture, that is, tough, like leather; in both cases it is very flexible, so that the creature can easily turn and twist itself about. 
Most of the Larve of the Diurnal Lepidoptera have sixteen legs, six of which, that is, three pairs, are placed on the three first segments of the body, the part which corresponds with what is called the thorax of the winged insect; these foremost legs appear to be the ones principally used for locomotion or travelling; they are of a hard substance, rather wide where they join the body, and gradually tapering down to the bottom, where they terminate in a strong claw, by which they can draw themselves along. Like the leg

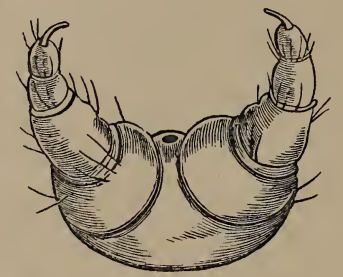

of the future $\mathrm{fly}$, each of them is divided into several segments, or, in other words, it has several joints, as represented in this figure. You will see that he is rather a bandy-legged fellow-this Caterpillar, but there is wisdom displayed in this, as in every other part of his structure, how admirably are these legs adapted for clasping and holding fast.

Now for the other, or pro-legs, as they are sometimes called; pro, in Latin, means for; therefore this is as much as to say these are not legs, but substitutes for 
legs, and such it appears they really are; their principal use seems to be to support the body, to the hinder part of which they are attached; a pair on each segment up to the ninth, and the remaining pair on the last; by adhering to the twigs or shoots, on which the animal crawls. You stare at the word animal applied to a Caterpillar, but it is quite correct. All living creatures are animals; you are one, and I am one, and the invisible animalcule that sports in a drop of water is one. But we will not stop to discuss the point now, having the pro-legs of our crawler to examine. I have said that they are soft and fleshy, or membranous legs, or thirgs that in some measure answer the purpose of legs. They are of a cone, or sugar-loaf shape, and can be lengthened and shortened at pleasure, like the horns of a snail; each of them is terminated by a triangular-shaped foot, if foot it may be called, at the bottom of which is a flat surface, or what may be termed the sole; on the inner edge of this is a row of small hooks, or claws, consisting of a long and short one alternately placed. When the foot is extended, these claws are turned outwards, and their curved points find inequalities on which they can take hold on almost any substance, however smooth it may appear. Here are two cuts;-one exhibiting this curious pro-leg with the foot expanded, and the other 
showing how a pair of them embrace and hold fast to a twig or branch.
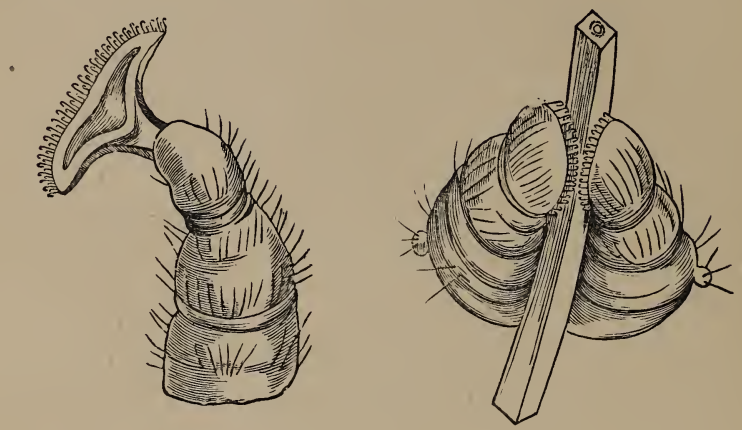

We have now to speak of the head of the Caterpillar, which is harder than the rest of the body, and is generally composed of two oval plates joined together; in the next cut is represented the under side of this head; that part marked $b$ is the mouth, consisting of an upper lip, with a notch in the centre; $c c$ are the

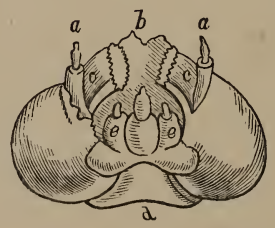

two strong mandibles, or jaws ; and $d$ is the under lip, near the top of which is a cone-shaped protuberance, from the centre of which, through a small hole, issues 


\section{Beautiful Butterfies.}

the fine silken thread which serves several important purposes in the changes which the insect undergoes; the spinnaret is the name which has been given to this organ; on each side of it is a similar shaped, but smaller, protuberance, marked $e e$; these are generally thought to be the palpi, or feelers.

The rapidity with which a Caterpillar eats proves that its cutting machinery is in good order, and well arranged for facility of working; if you watch the creature feeding, you will observe that the leaf on which it intends to operate is taken edgeways, and held steady between two of the fore feet. Before commencing, the body is stretched out as far as possible; the rapidly-moving jaws take off piece after piece, which is instantly swallowed, and at every bite the head is drawn in, until it comes close home to the legs, which hold the leaf, when another extension takes place, and another series of bites is commenced, till, by and by, the substance bitten is hollowed out like a half-moon. The notch in the upper lip, being even with the place where the jaws unite, appears to answer the purpose of a groove, to keep the margin of the leaf steady, and guide it in the proper direction.

The eyes and the antenna, or horns, have now to be noticed; the first appear to the naked eye like two little dark spots; the microscope shows that each of them consists of six distinct eyes, or lenses, arranged 
in a circle; they are placed in the fore part of the upper side of the head, and are therefore not seen in the cut. The antennæe, or horns, although usually large in the perfect insect, are small in the Lepidopte.rous larvæ, being composed of two or three short joints, fitting into each other, like the tubes of a telescope, like which, too, they can with some species be drawn in, so as to be almost imperceptible; the letters $a$ a point out their situation in the cut.

You will have noticed that Caterpillars differ very much in appearance;-some being smooth, and others rough and hairy; with some again the hairs are long and silky, with others short and harsh; some have them in tufts placed at regular intervals along the back or sides of the body; indeed they are seldom, if ever, irregularly placed; but whether few or many, a certain order of arrangement may be observable in the little tubercles, or lumps, from which they spring; these tubercles are placed in rows across the middle of the segments, and each segment is armed-for the spines may be considered as defensive armour-with a transverse, that is, a crosswise, series, varying in number from four to eight. The mode of arrangement and structure of these spines is exhibited in the section here given of a not uncommon species of British Caterpillar.

Why some Caterpillars should be hairy and others 
smooth it is impossible for us to tell; in His wisdom God has so ordered it, we may be sure, for some good and useful end. Upon the hairy species, it has been

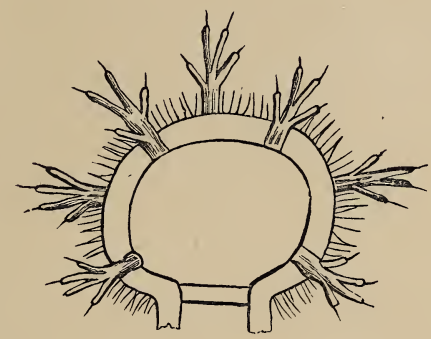

observed that the birds seldom prey; and there is no doubt some sufficient reason why they should be especially guarded from their enemies.

Many of the Caterpillars are very beautifully coloured and marked, appearing to have silken coats, embroidered with gems; this is more especially the case with the larvæ of some of the foreign day Lepidoptera; in this country those of the crepuscular division, or Hawk Moths, are the most beautiful, and to these we shall have to refer in another volume.

There is nothing more curious in the whole history of the Caterpillar than its moultings, or changes of skin, of which there are, at least, three, before the full size is attained. When it gets too big for its coat, the creature by a laborious effort, which is a painful, and 
at times even a fatal one, wriggles itself out, and leaves the old garment for whoever may take a fancy to it; but there is no occasion to go and get measured for another, as there would be with you or I, for a new one quickly forms around the body, fitting as nicely as need be. Sometimes the colours of this new coat are different from those of the old one, and the markings have a fresh arrangement, as if the fashions of the season had been studied in its preparation; but no, it was made in accordance with certain laws ordained from the beginning, in which there is no variableness nor shadow of turning. The fashion of a man's coat, or a boy's jacket, changes constantly; but the fashion of a Caterpillar's skin never: under certain circumstances it is always the same; its variations are regular, so that one who has observed these matters can tell what kind of covering a particular species at a particular age will have. The Naturalist will know at once the nature, and the character, and the age of a certain smooth or hairy worm which crosses his path, or feeds upon the leaf near at hand, by the shape and markings of its outer garment; suppose we could tell as much of men and boys by the cut and colour of their coats and jackets! Would not this be convenient?

Much might be said about the internal structure of the Caterpillar, but we cannot say it now; the same wisdom of design and nicety of adaptation is ex- 
hibited there as in the parts more exposed to observation.

We will now suppose the creature passed through all the changes incidental to the larva state;-this word in Latin means a mask; in this state the future fly is hidden or masked; Larve, the word we have

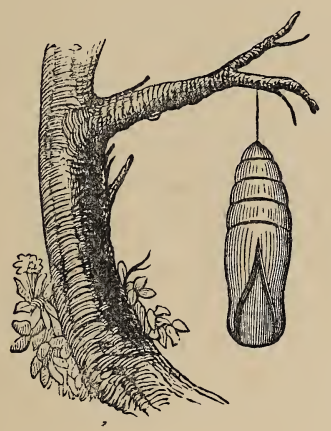

hitherto used, is the plural-it has eaten its own weight over and over again, may be a hundred times or more, in nettle, or cabbage, or some other leaves, and has now arrived at a ripe old Caterpillar age, so it prepares to go into what is called the pupa state, the second stage of its strange existence. Pupa in Latin means a puppet, a baby, a thing wrapped up, swaddled, as they say, of no particular shape-a lump; such is a chrysalis, as the insect, in the pupa state, is called. Singular, Chrysalis ; plural, Chrysalides from the Greek chrisos, golden. The Latin authors termed these aure- 
lia, from aurum, gold; because the cases of some of the pupa have a glittering appearance, as though they were partly composed of that metal. You may have seen one, that of the Tortoise-shell Butterfly, generally found near a bed of nettles, on which the Caterpillar feeds; it is rugged, uneven, angular in shape, as is also that of another common species, the Cabbage Butterfly; this latter is of a greenish-yellow colour, marked with black spots.

Some Caterpillars, when about to change into chrysalides, creep into holes and crevices, others bury themselves in the earth; some envelope themselves in a tissue of fine silk, as the silkworm does; this is called a Cocoon, of the origin of which word we must confess our ignorance; my readers will do well to try and find it out. Some of these chrysalides, again, suspend themselves to a bough, or other convenient object, by means of a silken cord, sometimes fastened round the middle, sometimes to one end, of the oblong case, as shown in this cut, designed by Thomas Hood to illustrate the popular ballad "I'd be a Butterfly." Here the part downwards is the head. A very interesting account is given by a naturalist named Reaumar of the way in which the Caterpillar proceeds to effect this suspension, and change from the larva skin into the pupa case; but it is too long for quotation here; byand-by you will, I hope, read it for youself in some 
larger Entomological work. It is related that it sometimes takes as long as twenty-four hours to effect these changes. Reaumar observes that "it is impossible not to wonder that an insect which executes them but once in its life should execute them so well. We must necessarily conclude that it has been instructed by a Great Master : for he who has rendered it necessary for the insect to undergo this change, has likewise given it all the requisite means of accomplishing it in safety."

When first the larva skin is thrown off, the chrysalis is soft and tender; it is covered with a sticky kind of fluid, through which portions of the future Butterfly can be clearly seen; like a thing closely packed up and put away until it is wanted. Gradually the fluid covering hardens, and closely enveloping all the parts of the insect, forms a case impervious to wet or any other atmospheric influence.

"It was a shrivelled shrouded form, Though but of late a living worm;

A caterpillar it had been, Once clad in suit of silken green;

But now how changed by nature's laws! Where are the eyes, the legs, the jaws? No signs of being can one trace In the cold mass; its outer case, Like cere cloth round a mummy spread, Is passive, motionless, and dead."

And there it swings, or lies wrapped up in its silken 
cocoon, or hid in the earth, or some suug hole or corner, until the time arrives for the release of the little prisoner, when-

"Lo! the shrouded thing

Loosed from its earthly covering,

From shape uncouth and dusky hue

Like some fair vision springs to view,

A glossy wing in burnished pride

Unfolding rises from each side;

Its tapering form in beauty dressed,

Like gold dust o'er a yellow vest;

Whilst hands unseen had giv'n the power

To gather sweets and suck the flower,

It is a Butterfly, as bright

As ever sparkled in the light."

And this third state of its existence is called the Imago, or perfect state of the insect; this term is the Latin for Image, whence comes Imagination, that faculty of the mind which produces images of things unknown, \&c.

I will now recall the stages through which the insect has passed before it assumed that glorious shape-that complete image of beauty, in which it now hovers and flutters before our eyes-

"The brightest and the lightest thing

That flits about on sportive wing ;"

and to impress these more deeply on your memory, 
will place, beneath the name of each, its pictorial representative.

The appearance of these creatures in their various states of Caterpillar, Chrysalis, and Butterfly, is so strikingly dissimilar, that it was long a general belief

LARTA.

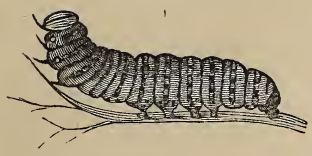

Caterpillar.
PUPa.

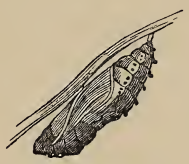

Chrysalis.
ImaGo,

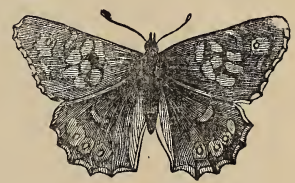

Butterfly.

that they underwent, at each successive stage, a complete transmutation, or change from one being to another; "but it is now clearly seen," says the naturalist Swammerdam, "that within the skin of the Caterpillar a perfect and real Butterfly is hidden, and therefore the skin of the Caterpillar must be considered only as an outer garment, containing in it parts belonging to the nature of a Butterfly, which have grown under its defence by slow degrees, in like manner as other sensitive bodies increase by accretion," that is, by growing or gathering of new matter. In every Caterpillar, therefore, it would seem that from the earliest period of its life there exists the germ or seed, if I may so call it, of the future fly, even as in the interior of the 
unexpanded bud may be discovered the germ of the future flower. So that all these changes are but a series of developments, a throwing off of outer coats, so to speak; and showing more and more clearly the perfect form within. All this is very wonderful, and worthy of our closest study and attention. So striking did these changes which the insect undergoes appear to the ancient Greeks, that they regarded the Butterfly as the fittest emblem of the soul of man; accordingly we find that their word Psyche, pronounced Syke, with an accent on the last letter, signifies both the human soul and a Butterfly. And very beautiful and appropriate is this emblem. How like a rising from the tomb and soaring upward to the realms of light, is this bursting forth of the imprisoned fly from its dark chrysalis chamber, to spread its glittering wings and float aloft in the golden sunshine. The poet Rogers has written some fine lines upon this subject, which, I think, you will be able to understand and appreciate: here they are-

"Child of the sun! pursue thy rapturous flight, Mingling with her thou lovest in fields of light; And, where the flowers of paradise unfold, Quaff fragrant nectar from their cups of gold, There shall thy wings, rich as an evening sky, Expand and shut in silent ecstacy.

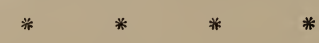


Yet wert thou once a worm, a thing that crept

On the bare earth, then wrought a tomb, and slept;

And such is man! soon from his cell of clay,

To burst a seraph in the blaze of day."

And now let me read to you a lesson of moral instruction, which the natural history of this insect is calculated to enforce; I will do it in the words of a German fabulist, or writer of fables; this story is called an Allegory:-A humming-bird met a Butterfly, and being pleased with the beauty of its person and glory of its wings, made an offer of perpetual friendship. "I cannot think of it," was the reply, "as you once spurned me, and called me a drawling dolt." "Impossible," exclaimed the humming-bird, "I always entertained the highest respect for such beautiful creatures as you." "Perhaps you do now," said the other, "but when you insulted me, I was a caterpillar. So let me give you this piece of advice: never insult the humble, as they may one day become your superiors." No, never insult the humble, nor despise that which is mean-looking, merely because it is so. The smallest and lowliest creatures have in them much that is worthy of admiration, aye, even of respect, for they are all the works of one Great Creator, and you know not what they may be destined to.

" Look round creation, and survey

Life springing forth from life's decay : 


\section{Beautiful Butterfies.}

In gladsome April view the tree

Resume its verdant livery ;

From bars of ice the river freed,

Pursue its course along the mead:

And earth, escaping from th' embrace

Of winter, show a joyous face.

E'en thus the worm, though lowly found,

Groping its way upon the ground,

May yet revive, a creature fair,

And wander 'midst the realms of air."

We will now examine a little into the structure of the perfect insect-a common Butterfly; and a truly wonderful piece of living machinery we shall find it. The body is divided into two principal divisions, called the Thorax, meaning the breast or chest, and the Abdomen, or stomach. The first of these is composed of three segments, something like those described on the Caterpillar, and the last of six or seven; these two sections of the body have, as in most insects, a very narrow line of connection; they are both covered with hairs, more or less long in different species. The upper one is always thicker than the lower, because to it are attached the organs of motion-the legs and wings, the muscles of which, especially those of the latter, are numerous and powerful. The legs are six in number, and this is the case with all true insects: there are three on each side, and their points of junction with the body are pretty close to, and at about 


\section{Beautiful Butterfies.}

equal distances from, each other. In each leg there are three principal divisions, the thigh, the tibia, or pipe, and the tarsi, or toes, just as there are in the human leg, only the shape differs considerably, as you know. A Butterfly would not look well with silk stockings, because he has no calf; the thigh is often fringed with long hairs, and the tibia armed with a spur in the middle, and two others at the top; the tarsi are five-jointed, and furnished with two claws at the extremity, which are often what is called bifed, that is, cleft in two; this word comes from the Latin $b i-$ two, whence also comes biped-a two-legged creature, and several other words beginning in the same way. When I tell my little boy he is a biped, he says, "and you are another," and he is quite right, for we are all bipeds -bi, two ; pede, foot-literally, two-footed, as quadruped is four-footed; and tripod, a kind of stool that stands upon three feet; from the Latin quatuor four, tres three; also the roots of many English words. But why do I trouble you with all this about roots and derivations? because I am desirous of making you look into things, to be thoughtful and inquiring, so that you may know the reason why this or that name is applied to a certain object or operation. This is the way to learn. Some Butterflies are called tetrapod, or fourfooted, because, although they have six legs, they have but four feet, two of the legs being what are termed 
spurious or false, there being only one joint in the tarsis, and consequently no claw or foot.

From the legs we go naturally to the wings, they being situated very close together; of these butterflies have two pairs, the upper pair being generally of a triangular form, and the lower pair nearly circular; the shape, however, as well as the size, varies greatly in different species; and the difference in the colours and markings is, as you know, great indeed. I have already spoken of the mealy powder or scales (feathers they are sometimes called), in which the colour resides, and may, therefore, pass on to observe that the thin membrane, of which the wing itself consists, is traversed by small tubes called nervures, filled with air and airlike fluid, which acts so as to expand the wing when the fly first issues from the pupa state, and to strengthen and keep it extended afterwards; the principal nervures rise from the point where the wing joins the body, and where there is a horny scale covered with tufts of hair, so that it resembles a little epaulet, such as the soldiers wear; and the parts between the main pipes, as they may be called, are termed by naturalists areolets, that is, little spaces, from area, an open or flat surface between lines or boundaries.

Naturalists consider the upper wing of the Butterfly divisible into three of these spaces, and across them from branch to branch ramify, that is, spread out, 


\section{Beautiful Butterfies.}

smailer pipes, so as to form a complete network, as I have before observed. In some species these minute veins are much more numerous than in others, and in some they scarcely or at all occur.

It may be observed that Butterflies, when at rest, generally carry their wings upright, so that the backs of them meet together, and only the under sides are visible; and here is an obvious mark of distinction from the Moths, which keep theirs flat, even with the ground, or whatever they may rest on, and so show only the upper part; the flight of the Butterfly, too, is more wavering than that of the Moth generally. It does not go in a direct line, but keeps rising and falling, and herein often lies its safety from the pursuing bird, with whose beak it is level one instant, and the next far above or belowit. Thus it is that the weaker creatures are often able to elude or baffle the pursuit of the stronger by superior cunning or agility-a something which is given as a compensation for want of power, and a means of preservation from their foes.

Not all the Butterflies, however, are distinguished by this irregular and fitful mode of flight; some of the larger sorts, which are strong upon the wing, go more directly to their object, and sometimes even make way against currents of air which would make the less weighty and powerful flutterers seek shelter in a lilybell, or a tent of green leaves. A practical entomolo- 
gist can generally tell the species of a Butterfly by its mode of flight, so much difference is there in this respect.

One very important part of the structure of the insect I have not yet described, that is, the head, the most conspicuous and curiously constructed organ of which is the long flexible tube used for sucking the juices out of the nectaries of the flowers; this is of a cartilaginous or gristly substance, arranged in rings, woven together, as it were, by means of minute fibres, so that it can be curved or twisted in any direction, with great ease and rapidity. This tube is, in reality, the mouth of the creature, for it has no other, nor any occasion for one, as it lives by suction, and is hence classed among the Haustellated (from the Latin Haustus, a draught) or suctorial tribes of insects. The Proboscis or trunk of the Butterfly is divided into two distinct portions, which can be separated throughout their whole length, each portion being grooved on the inner side; they form, when united, a sort of canal of a squarish shape, through which passes the nourishment which the insect sucks up. The union of the two halves of the trunk is effected by the interlacing of an immense number of threads, which form a kind of fringe along the edges, and so close is it that the canal is perfectly air-tight; and on each side of it there runs from top to bottom a circular passage, the use of which does not appear to be very 


\section{Beautiful Butterflies.}

clearly known, although it is thought most likely to be the transmission of air for the purposes of respiration or breathing, which, however, is mainly carried on by means of pores, or very minute openings in the sides of the body, called stigmata, from stigma, a mark, these pores presenting the appearance, under the microscope, of little pits or dots. Near the outer extremity of the trunk, which, when not in use, is curled up like the spring of a watch, are generally a number of projections resembling leaflets; a scientific naturalist would call them papilla, the Latin for nipples. Reaumur supposes that the use of these is to steady the organ, by adhering to the sides of the flowers into which they are inserted. In order that my readers may have a clearer understanding of the structure of this wonderful little instrument, I have caused three cuts to be executed. $A$ is a mag.

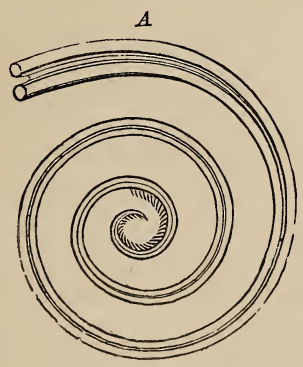

nified view of the trunk, exhibiting its general form, and the papilla near the tip. $B$ is a highly magnified 
section in which the mode of connection is shown, with

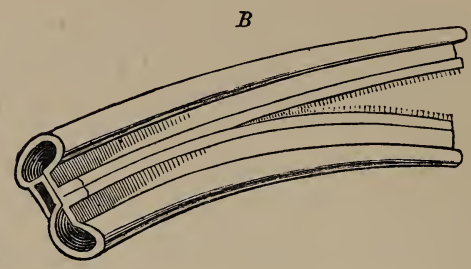

the central and two lateral or side canals. $C$ is another

C

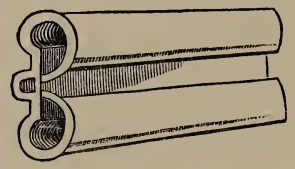

section showing the under side. Is it not marvellous that all this is in a little tube not much thicker than a hair ; human skill and ingenuity can do much, but they would surely be at fault here.

We have seen that the proboscis of the Butterfly is composed of two distinct parts, which may be considered as occupying the same place in the general structure of the insect, as the maxillae or under jaws of the mandibulated tribes. We have here two Latin words, and when I tell you their meaning, you will understand what I wish to express; maxilla, then, means the upper jaw-bone-the termination $a$ makes it plural; mandibula is the Latin for jaw, so the term above used 
would signify tribes that have jaws, as much the larger number of living creatures have. It was, perhaps, not quite correct of me to say that the Butterfly had no mouth, for there is a little cavity just below the insertion of the trunk, which, although it hardly deserves the name of a mouth, and does not appear to be used at all as yours and mine, or even that of the Caterpillar is, yet it must, I fancy, be so called.

And we must now speak of the oral appendages, that is, the parts which belong to the mouth. The word comes from the Latin os or oris. Now, if you should hear or read that a person has or intends to communicate with another orally, you will understand that it means by word of mouth-that is, by speech. This little cavity that I spoke of is covered by a small triangular plate, "which must be regarded," says an authority on these matters, "as the labium or under lip." There is another Latin word for you to remember. Those letters of the English alphabet, such as b, p, v, f, $\mathrm{m}$, which are pronounced chiefly by the lips, are called labials, you know, or should know. You have, no doubt, noticed two short points projecting from the front of the head of a Butterfly-I do not mean the horns, which are long, slender, and nobbed at the ends -but I mean what are called the labial palpi.

In describing the head of the Caterpillar, I spoke of the palpi or feelers; this latter term comes from the 
Latin palpus, and it expresses the action of feeling gently or timidly, just as the snail does, you know, which draws in its horns directly they come in contact with anything. The term also means to flutter, hence you may hear a weak person say that his heart palpitates, when he has used great exertion, or been overexcited. Now, both these meanings will apply to the palpi of the Butterfly, which sometimes has a quivering or fluttering motion, and I have been thus particular in explaining them, in order that you may see what great significance there is in scientific terms generally. Ignorant people often wonder what use there can be in these long names, but you here see that they have a use, and you may also see how necessary to a right understanding of them is a knowledge of the Greek and Latin languages, on which they are chiefly founded. These languages may be considered as the keys to all the sciences-by all means try and obtain possession of these keys, for they will well repay you for years of study; with them to guide you, and the habits of observation and method, and analysis, which their very acquisition will induce, much that now seems difficult and strange will be clear and simple, and full of order. Now let us go back to the palpi, it would be palpa if only one, but that there are two is quite palpable, that is, plain-they can be seen and felt, and those who have examined them through a microscope, tell us that they 
are three-jointed, and in shape like this. In this cut, the letter $a$ indicates the organ I have been describing; and $b$ the antenna, plural antennce. The term I have

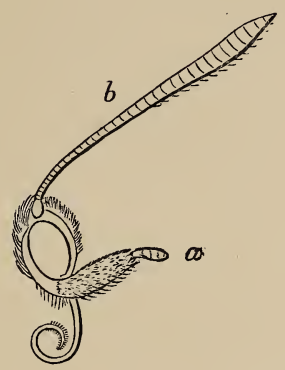

used before in describing the insect in its larva state; but I did not then speak of its derivation. The Latin word antenna means the sail-yard, as it is called, of a ship, that is, the piece which crosses the mast, and to which the canvas is affixed; these horns of the insect, in some cases sticking out in nearly opposite directions to each other, suggested the idea of the cross-pieces on a mast, and so the same Latin name was applied to them. They are generally of considerable length, and consist of a great number of joints, usually increasing in thickness towards the extremity, where they form a kind of knob; this formation you must often have noticed; it is peculiar to the Diurnal Lepidoptera, and by its variations of shape affords an obvious distinction 
between different genera. In the Moths the antennce are often beautifully feathered and fringed, but we do not find this the case with the Butterflies.

I have now only to speak of the eyes, which are of two kinds, the stemmetic or simple eyes, which are usually two in number, and placed on the crown of the head, where, if seen at all, which is not the case in all species, they appear as little clear spots, nearly covered with hairs and scales. Their use as organs is somewhat questionable, but they may be of service in some way, as yet undiscovered by the investigation of scientific men. The ordinary or compound eyes, as they are called, are plain enough; they occupy a great part of the head on each side, and project from it like a half globe; unlike the human eye, which can move in various directions, they are fixed, but to compensate for this they are composed of an immense number of little lenses, each of which is capable of reflecting a perfect image, so that on whatever side you approach a Butterfly (and it is the same with most other insects), it can see you without moving its head or rolling its eye-ball in the socket, as you or I would be obliged to do, to be aware of any danger approaching from a direction other than the front. Naturalists tell us that they have counted as many as seventeen thousand three hundred and twenty-five lenses in a singe eye; double that for the pair, and it gives thirty-four thousand six hundred 
and fifty little circular looking-glasses, to a single pair of eyes, contrived and fashioned for an insect destined to live but for a few hours. I can tell you nothing more wonderful than this, so I think I may as well bring my description of a Butterfly to a conclusion, the more especially as I have mentioned all with which it is necessary for you to be acquainted about the history and structure

Of that wonder of wonders, the bright-winged fly,

That flits to and fro in the azure sky;

That has died, and been buried, and sprung from the tomb,

To live amid sunshine, and beauty and bloom.

As the subject of my present volume is 'British Butterflies,' I would say a few words with especial reference to them. They are neither so large nor so beautiful as some of the foreign ones, yet are there many of the native species remarkable for elegance of form and richness of colour, as the examples here given will serve to show; and, by the way, here let me mention one peculiarity in the wings of the Butterfly, which should not go unnoticed-the under, as well as the upper, side of this wing, is beautifully painted by the Divine Hand, often of a different pattern nom that displayed on the outer surface. How elaborately finished are all God's works! How perfect in every part!

The Lepidopterous order of insects ranks next to the 
Coleoptera, or Beetles, in point of numbers ; in England, where the variable and moist climate is certainly unfavorable to their increase, there are not much less than two thousand species: between two and three thousand of the Diurnal Lepidoptera alone have been discovered and described all over the world; and of this division of the order seventy-five species inhabit Britain. At the end of the volume will be found a complete list of these, arranged according to their genera, with a specification of their times of appearance, and of the places they usually frequent.

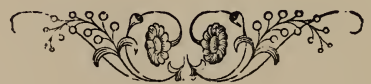


BUTTERFLY HUNTING. 



\section{BUTTERFLY HUNTING.}

190. N a boy the desire to capture one of these beautiful insects that comes dancing and fluttering before his eyes, as if to invite pursuit, is natural and instinctive; off goes the cap without any other thought than how the prize is to be obtained; trampled flower borders, torn trousers, even bruised limbs, are as nothing in the account, and probably he sits down at last, flushed, heated, tired, and disappointed; but it is only to start up again and renew the chase, should the same chance of a capture offer itself.

\section{"Before your sight}

Mounts on the breeze the Butterfly, and soars,

Small creature as she is, from earth's bright bowers Into the dewy clouds."

And while you stand wondering what has become of the insect which seemed but now within your grasp, another brighter and more beautiful still issues from the variegated tulip cup, and as Mrs. Hemans has it, 
"like an embodied breeze at play," wavers about amid the flowers; and off you go again in hot pursuit, like the child of Vigillia, in Shakspere's play of 'Coriolanus,' but not like him, I hope, to get into a rage and destroy wilfully the poor fly, because you have a tumble or two in endeavouring to catch it. "I saw him," says Valeria to the boy's fond mother, "run after a gilded Butterfly, and when he caught it, he let it go again, and after it again, and over and over he comes, and up again-catched it again; or whether his fall enraged him, or how 't was, he did so set his teeth and tear it; O, I warrant how he mammocked it." This is by no means a pleasing picture, but $\mathrm{I}$ fear it is too often realised among young Butterfly hunters, who, if they do not get into a passion and designedly destroy the object of their pursuit, frequently do so accidentally in their efforts to secure it. So delicate and fragile is the creature, that but the brush of a cap, or the slightest pressure of a finger, will, if it crush not that wonderfully organized frame, and render it lifeless, take away much of its beauty, and with it, no doubt, much of its capacity for enjoyment. And after all, if their efforts are crowned with success, how poor is the prize gained. The poet Byron has some beautiful lines on this subject which I should like you to read:- 
"As rising on its purple wing.

The insect queen of Eastern spring,

O'er emerald meadows of Kashmeer,

Invites the young pursuer near;

And leads him on from flower to flower,

A weary chase, and wasted hour,

Then leaves him as it soars on high,

With panting heart and tearful eye."

The poet thus, after saying, which is true, how fullgrown children, that is, men, are lured by things which, if as beautiful, are also as fragile as Butterflies, supposes that the prize is gained, and goes on-

"The lovely toy so fiercely sought,

Hath lost its charm by being caught,

For every touch that woo $d$ its stay,

Hath brush'd its brightest hues away,

Till charm, and hue, and beauty gone,

'Tis left to fly or fall alone."

We have heard of an enthusiastic entomologist who followed a Butterfly for nine miles, in the hope of capturing it; and this must be set down to the account of ardour in scientific investigation. Not all grown Butterfly hunters, however, would we hold so excused, many, very many, more unfortunate insects are swept down with the net, and pinned out in the collecting case, than are required for the purposes of science; and this wholesale destruction of insect life we think scarcely compatible with that abhorrence of cruelty, and rever- 
ence for the works of the Great Creator, which is enjoined by Him

"Who formed the gilded fly, and o'er its wing,

A picture, decked in rainbow colours, drew;

To sport amid the sunshine of the spring."

My young readers must not suppose from this that I would harshly condemn in them that love of Butterfly hunting which is common to all children. I have felt it myself, and know how strong is the temptation to follow " the painted toy." There is perhaps no prettier sight than such as that described by Grahame, in his poem on July, when

"At noontide hour from school the little throng Rush gaily sporting o'er the enamelled meac, Some strive to catch the bloom-perched Butterfly;

And if they miss his mealy wings, the flower From which he flies the disappointment soothes."

In gazing on such a scene as this, I become a boy again, and am half inclined to join in chase myself, and to whoop and halloo with the maddest there; but then the thought occurs - would it be right to risk even doing injury to a creature so wonderfully fashioned, and to shorten the little span of its joyous existence. Let this thought restrain your hand; run and leap as much as you like, it is 
natural to your age and good for your health to do so, and follow

"The little fly with wings of sunbeams,"

from end to end of the "green meadow, but do not attempt to catch it; let it be to you as a sacred thing, sent by God to beautify the earth, and delight your eyes, but by no means to be wantonly injured or destroyed.

I should like to repeat to you many beautiful poems which have been written on the Butterfly, and many striking observations that have been made on it by naturalists, such as Messrs. Kirby and Spence, whose admirable work on Entomology I hope you will read when you are older, but I cannot do so now, as my book is but a small one, and I shall want all the available space to describe the species of which figures are given. In the poems above spoken of allusion is sometimes made to the Butterfly as a fop-a light careless thing; thus Thompson says-

"While a gay insect in his summer shine, The fop, light fluttering, spreads his mealy wings."

The same poet too, in his 'Castle of Indolence,' speaks of it as an emblem of pleasure :- 
"Behold! ye pilgrims of the earth, behold! See, all but man with unearned pleasure gay;

See her bright robes the Butterfly unfold, Broke from her wintry tomb in prime of day, What youthful bride can equal her array? Who can with her for easy pleasure vie? From mead to mead with gentle wings to stray, From flower to flower on balmy gales to fly, Is all she has to do beneath the radiant sky."

Leaving unquoted those fanciful lines by Roscoe'The Butterfly's Ball,' and 'The Butterfly's Funeral,' with which many of my readers must be familiar, as well as other Butterfly poems which I have at hand, I will conclude this Introductory Chapter with some lines by the quaker poet, Bernard Barton, who thus addresses the bright insect-

BEAUTIFUL creature, I have been

Moments uncounted watching thee,

Now flitting round the foliage green

Of yonder dark, embowering tree;

And now again in frolic glee,

Hov'ring around those opening flowers,

Happy as nature's child should be,

Born to enjoy her loveliest bowers.

And I have gazed upon thy flight,

Till feelings I can scarce define,

Awakened by so fair a sight,

With desultory thoughts combine 


\section{Beautiful Butterflies.}

Not to induce me to repine,

Or envy thee thy happiness;

But from a lot so bright as thine

To borrow musings born to bless.

For unto him whose spirit reads

Creation with a Christian eye,

Each happy living creature pleads

The cause of Him who reigns on high;

Who spann'd the earth, and arch'd the sky,

Gave life to everything that lives,

And still delighteth to supply

With happiness the life He gives.

This truth may boast but little worth,

Enforc'd by rhet'ric's frigid powers :

But when it has, its quiet birth

In contemplation's silent hours ;

When surnmer's brightly peopled bowers

Bring home its teachings to the heart;

When birds and insects, shrubs and flowers,

Its touching eloquence impart.

Though many a flower that sweetly deck'd

Life's early path, but bloom'd to fade:

Though sorrow, poverty, neglect-

Now seem to wrap their souls in shade;

Let those look upward, undismay'd,

Turn thorny paths in anguish trod,

To regions where in light array'd,

Still dwells their Saviour and their God. 
Sport on then, lovely summer fly,

With whom began my votive strain:Yet purer joys their hopes supply, Who by Faith s alchemy obtain Comfort in sorrow, bliss in pain, Freedom in bondage, light in gloom, Through early losses, heavenly gain, And life Immortas through the Tomb.

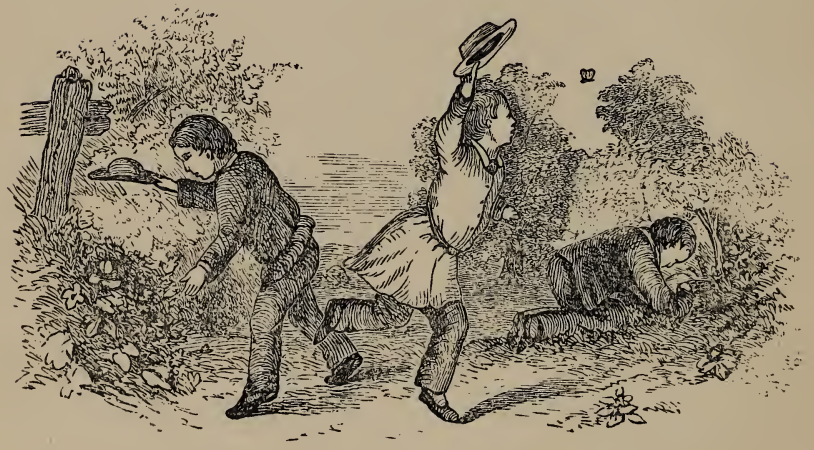


DESCRIPTION OF SPEOIES. 



\section{SWALLOW-TAIL.}

PLATE I.-FIG. I.

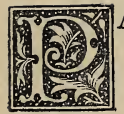

APILIO MACHAON is the name applied by Linnæus and most naturalists to this large and beautiful species of Butterfly; the meaning of the first, or generic name, has already been sufficiently explained; the second, or specific name, has reference, it is likely, to the peculiar shape of the two lower wings of the insect, from each of which issues, as will be seen by a reference to the plate, a projection shaped like a dagger or knife, the Latin word for which is Machera. There are only two British Butterflies which have wings of this singular form; and it is likely that few of my readers have seen either of them, except, perhaps, in the cases of the British Museum, or some other entomological collection. The species to which our attention is now directed, is the largest Butterfly found in Britain, sometimes measuring as much as three inches and three quarters across the expanded wings, of which it will be seen the groundcolour is yellow, with black markings; these markings being remarkably bold and distinct, and the broadest of them being powdered over with very small dots, 
which look like gold dust; and some of the yellow portions have a like sprinkling of little blue dots; on each hind wing, as it is called, is a patch of a rich purple colour, and on the inner side a red spot like a fiery eye. The body of the insect is like black velvet powdered with gold; and altogether it is so richly dressed, so gracefully formed, and so large of size, as well to deserve the title bestowed upon it by one naturalist, named De Geer, of Papilio Regina, the Queen Butterfly. And where think you does her Queenship delight to hold her court? On the sunny uplands, and in dry pastures, gay with Nature's gold and silver-the buttercups and daisies? Nay, amid the moist fens and reedy islands, which abound in the shires of Lincoln, Cambridge and Huntingdon; there it is that the Swallow-tail Butterfly is most plentiful, and may be taken from the beginning of May to the end of August, by those who are venturous enough to follow it into the swampy grounds, amid which it delights to dwell. Here, too, may be found the beautifully-marked green and yellow caterpillar, with its black bands, and rows of little rings like eyelet holes across the back, feeding away upon the marsh parsley, the wild carrot, and the fennel, and other plants which flourish in such moist situations. From June to September is the feasting time; in the latter month the change into a chrysalis takes place, and a curiously- 

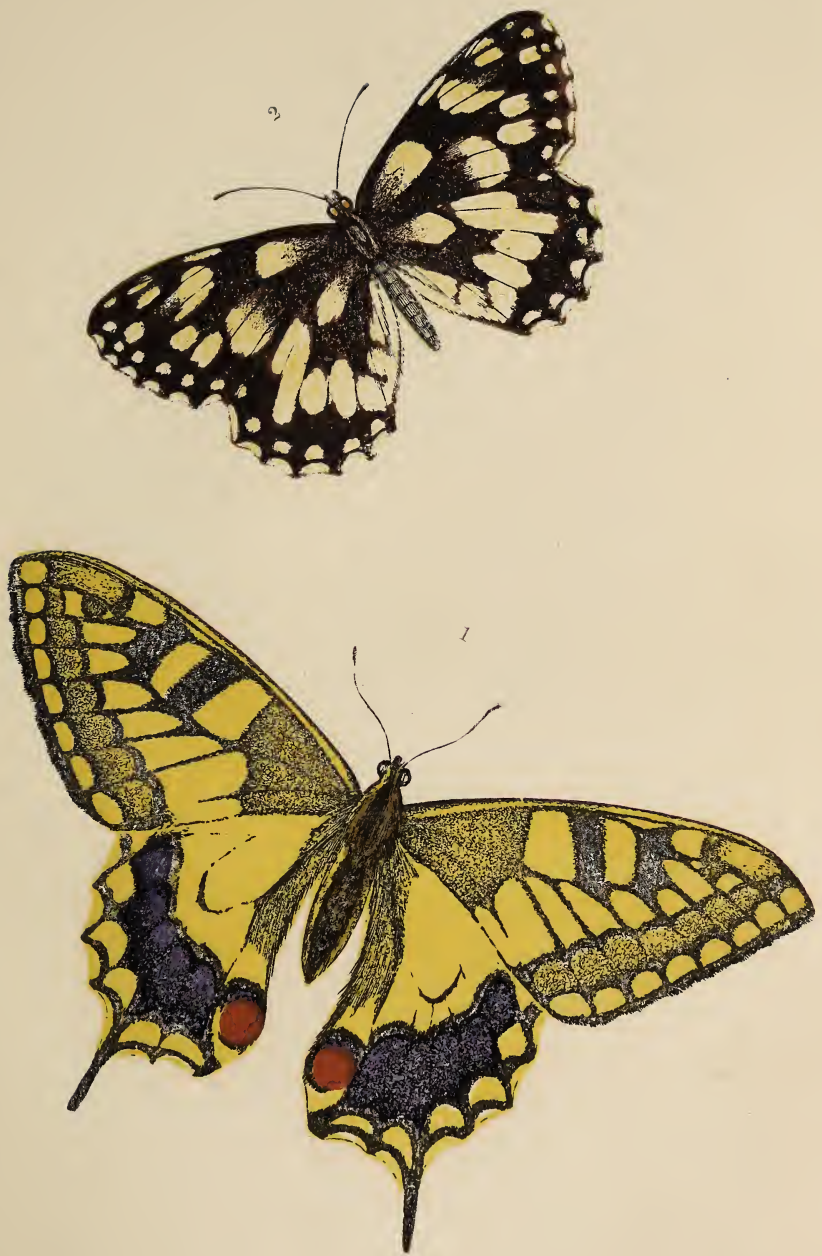

1. Swaliow-tall. Marbled White. 

shaped case it is that the voracious feeder goes to sleep in-all points and angles, of a light green colour, with yellow marks, and a row of dusky dots down each side.

There are several English counties besides those before named in which this Butterfly has been found, but in none of them is it so plentiful as in those low and moist districts,-

Where the dragon-flies dart 'mid the rustling reeds, And the great sleek water-rat builds and breeds;

Where the moorhen glides through the waving sedge,

And leads her young to the marshes' edge;

Where the stagnant pool is with duckweed green,

And gnats rise in clouds when the air's serene;

And the alder grey like a sentry stands

To warn men's feet from the swampy lands.

Since the draining of the fens in Lincolnshire, and other parts of the country, it is said that the beautiful Swallow-tail has become less plentiful, and a fear has been expressed that entomologists may in time lose this most conspicuous ornament of their cabinets. Well, better so than suffer such waste and barren spots to remain uncultivated; such nurseries of fever and pestilence to send forth their unhealthy exhalations, and spread sickness and death throughout the surrounding districts. Wholesome food and pure air for man is of far more consequence than the preservation of an insect, however beautiful and rarc; so let them 
drain Whittlesea Mere, as they have lately been doing, and turn the fens into farms, where something more than flocks of cackling geese can be bred and fed; even although the race of Swallow-tails should become extinct in consequence. But we have little fear of this; for many centuries to come there will be marshy waste places, where umbelliferous plants, such as the wild parsley, carrot, and fennel grow and flourish, and where, if anywhere, one may expect to find this Queen of British Butterflies, in company, perhaps, but this would be a rare chance indeed, with the Scarce Swallow-TAIL, called by naturalists Papilio Podalirius, of which but a few specimens have been taken in England. Why it was called Podalirius, we cannot tell,- - this was the name of a son of the ancient Greek physician, Esculapius. Both in shape and markings this insect differs considerably from the more common kind-the wings are more pointed and slender; there are no red eyes in the lower ones, nor patches of purple, but dark blue spots shine on each side in the place of them. The Caterpillar is shorter and stouter, green with yellow and red markings. It is said to feed on the leaves of the apple, sloe, plum, peach, and almond; the chrysalis is light brown.

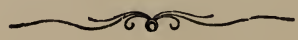




\section{MARBLED WHITE.}

PLATE I.-FIG. II.

APILIO, or Hipparchia Galathea, is the Latin name of this species. You will remember what I told you about the genera into which naturalists have divided the members of the animal and vegetable kingdoms. Hipparchia is a genus of Butterflies including many species, of which this is the largest, and perhaps also the handsomest; most of the others differ from it greatly in the colours of the wings, which are brown of various shades, sometimes tinged with red, and sometimes with dusky yellow. The Caterpillars are nearly always green, more or less marked with yellow, and sometimes with red. They feed on different kinds of grasses; that called the cat's-tail grass being the favourite food of the larva of the Marbled White, which obtains its English name from having its wings chequered and veined as we sometimes see marble; these wings, however, are not, strictly speaking, white, but a pale yellow; in some there is a much greater proportion of black than in others.

But we have got something more to say about the scientific title. Hipparchus, we find, was the name of 
an ancient astronomer; but why it applied to this genus of insects we cannot tell. A group of crustaceous animals, or shell-fish, has had the term Galathea given to it by some naturalists, but why, our reading does not inform us, any more than it does wherefore a certain species of Butterfly should be so called. Lac is the Latin, and gala the Greek, for milk; hence we have galaxy, that collection of stars in the heavens called the milky way; Galactites, precious stones, of a milk-white colour, etc. The wings of this beautiful fly are of a milky, or rather of a creamy tint, and hence perhaps may have originated the specific name of the insect, which appears in its perfect state in the months of June and July.

It may be found in every county in England, although only in certain spots, or localities, as they are called; usually in lonely places, in and near woods, or on wide open downs or moors. It measures from one to two inches and a half across the extended wings; the Caterpillar is about an inch and a quarter long, with yellow stripes running along the sides of its thick, green body; the chrysalis is scarcely half the length, of a light brown colour; it is usually found suspended from the stalk of the cat's-tail, or some other grass. 


\section{SCOTCH ARGUS.}

PLATE II.-FIG. I.

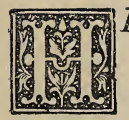

IPP ARCHIA BLANDINA. This is a very beautiful, although at first sight it appears a sober-coloured Butterfly; the wings, of a rich brown, ornamented with veins and patches of bright copper colour, and beset with small eye-like dots, are well deserving of a close examination. They measure, when extended, from an inch and a half to two inches across, and their outline is at once bold and graceful; the under sides of the hinder pair, seen when the insect is at rest, have on them two broadish waves of a grey tint, and both pairs on either side are margined with yellowish brown, which being crossed with darker lines, looks like a delicate fringe.

This insect, which is not uncommon in many parts of Scotland, especially the southern counties, has also been captured in Northumberland, Durham, and Yorkshire, as well as some other parts of England, in which country, however, it is by no means plentiful.

The Caterpillar is light green, with brown and white stripes, running lengthwise, these would be termed longitudinal stripes; the head is of a reddish colour; 
what it feeds on does not appear to be known; nor as far as we can learn, has the chrysalis been discovered.

Respecting the name, we can only say that Argus refers to the little spots on the wings, that being the designation in the ancient mythology of one who is said to have had a hundred eyes; so we say of a very watchful person, like your schoolmaster, for example, that he is argus-eyed-he sees everything. But for that matter, all Butterflies are Arguses, for, as I have already shown, they have each a great many more than a hundred little reflecting lenses; to these real eyes, however, the term does not refer, but to the eyelike rings with dots in the centre, which appear in the wings of this and many other species. The Wood Argus (Hipparchia Ageria) and the Arran Argus (H. Ligea) are two of these; the latter closely resembles the one we have just described. It is very rare in Britain, having only been found in the Scottish Isle of Arran, whence it takes its name. The former is an elegant fly, with dark brown wings, specked with buff-colour, from which the little eyes peep out; the under sides are much lighter, beautifully streaked and mottled. This insect is found in woods and lanes all through the country, from April to August. It is sometimes called the Wood Lady, or Speckled Wood Butterfly.

We have before mentioned three generic names- 
Blandina, Egeria, and Ligea, to what do they refer? The nearest approach we can make to the first, in the Latin, is Blandusia - the name of a fountain near the country seat of the ancient Roman poet, Horace. Bland, you know, in our language, means soft, smooth; and this comes from a Latin root having the same sound and signification.

Ageria, in the old mythology, was the name of a disconsolate maiden, who took to crying so, that it was thought best to make her a fountain at once; and so travellers tell of the grotto of Egeria, near Naples, whose trickling waters do not taste at all like salt tears.

Ligea was the name of one of the Nereides; and who are they? you may well ask. Oh, they were nymphs of the sea, fifty of them, and all sisters-a nice little family; they lived in grottoes and caves on the sea-shore, all decked with shells and shining spars, and when they went out for an airing, they rode upon dolphins. They had the power of calming the waters, and so sailors in old times used to pray to them for prosperous voyages. But what has all this to do with Butterflies? I am sure I do not know; ask the grave naturalists who gave such pagan out-of-the-way names to our little brown Arguses, and led us away into the region of myths and fables. 


\section{WHITE ADMIRAL.}

PLATE II.-FIG. II.

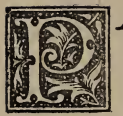

APILIO, or Limenitis Camilla. This is an insect most usually found in the shady woodlands of Essex, Sussex, Hampshire, Suffolk, Kent, and Middlesex; it is by no means a common species in any part of England, and is remarkable rather for grace and elegance of form than richness of colour. The wings, which, when expanded, sometimes measure as much as two inches and a half across, are, on the upper side, of a dull brownish black, with a broad band crossing each; this is very irregular in shape, and varies considerably in breadth in different individuals; there are also white specks scattered here and there about the wings, the under sides of which are of a light reddish brown, with the white markings of the upper sides showing through ; near the body of the insect, they become of a grey tint; the back and upper parts of the body also assimilate to the outer surface of the wings in hue.

The Caterpillar, which feeds on the honeysuckle, is from an inch to two inches long; of a green colour, ringed and ornamented with faint red lines, and tufts 
of hair along the back. The angular-shaped chrysalis is pale brown, marked with black lines and golden spots. It has a curious projection, like a knob, on the back, and where the head of the insect is are two distinct lumps. It is found suspended by the point to a honeysuckle or some other stem.

English naturalists, we believe, have not been fortunate enough to discover this gilded mummy case, although many a hunt has taken place in the hope of doing so; neither has the insect in the larva state been found in this country. Those few who have been fortunate enough to have opportunities of observing the fly on the wing, have been struck with the peculiar grace of its movements. Thus the Rev. Mr. Haworth says, "The graceful elegance displayed by this charming species when sailing on the wing, is perhaps greater than can be found in any other we have in Britain." And the Rev. Everett Sheppard tells us that "In its beautiful flight, when it skims aloft, it rivals the Purple Emperor, which it strongly resembles in appearance. It seems, however (unlike the latter), to avoid the sunbeams; for it frequents the glades of woods, where it rapidly insinuates itself by the most beautiful evolutions and placid flight through the tall underwood, on each side of the glades, appearing and disappearing like so many little fairies," and seeming, as the rev. gentleman might have added, to say to the pursuer, 
"Through the wood, through the wood, follow and find me, Search every hollow, and dingle, and dell."

With respect to the scientific name, it may be observed that Limenitis may have reference to the flashing appearance of the white bands on the wings, as the insect flies about in the dusky glade; leme being an old English word, signifying a ray or flash. Camilla, in the mythology, was the name of a queen of the Volschi, so swift of foot, that she could pass over a field of corn without bending the ears, and over the sea without wetting her feet. We should rather believe that our dusky-winged Camilla could do this than the Volschian queen, however swift-footed she might have been.

This insect, we are told, is not rare on the continent of Europe, where there are four other species belonging to the same genus, and closely resembling it. 


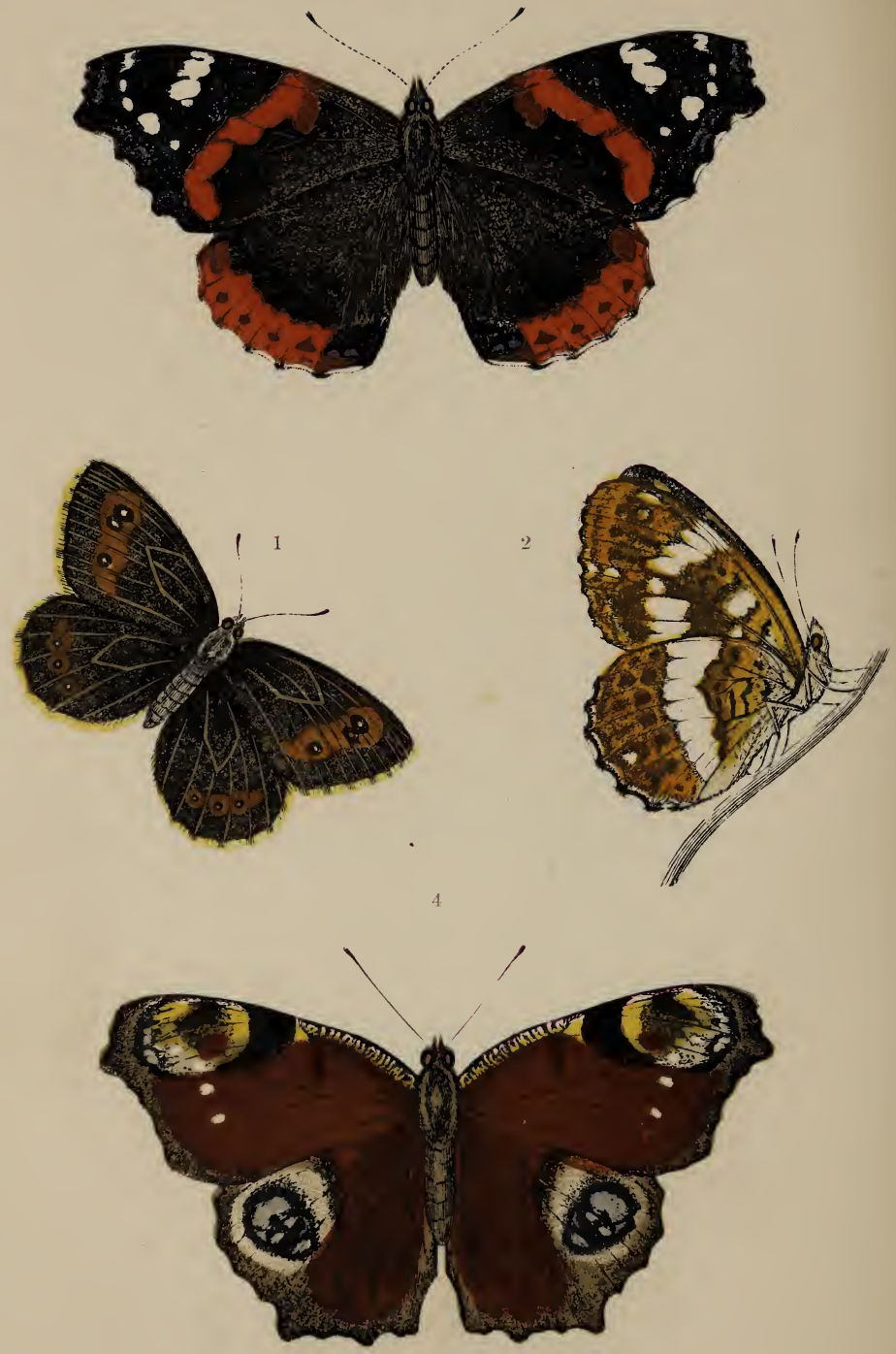

1. Scotch Argus. 2. White Admiral. 3. Red Admiral.

4. Peacock Butterfly. 


\section{RED ADMIRAL.}

PLATE II.-FIG. III.

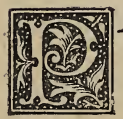

APILIO, or Vanessa Atalanta. This large and magnificent Butterfly is by no means uncommon. It comes out of the chrysalis in August, and may frequently be seen flitting from flower to flower in the garden, seeming to prefer the large globe-like dahlia and the little green blossoms of the ivy, two very different objects of regard; doubtless, however, the nectar of the one is as sweet as that of the other, and little need the gaily-dressed insect care about richness of colour, for he has that himself; look at him now, as he sails proudly in the autumn sunshine, which seems to sink into the soft velvety down of his rich brown wings, and give them a golden gloss.

The colour is deep, approaching to a black, and across the middle of each upper wing a painter seems to have drawn his brush filled with the brightest vermilion; along the bottom edge of the lower pair, there is also a band of the same colour dotted with dark brown or black ; there are several irregular white specks on the upper ones towards the angles of their widest 
expansion, where they measure in some instances as much as three inches across; near the tips is an indistinct wave of purple, which catches the eye in certain lights, and all round the margins of both pairs is a fringe of white arranged like a chain of little crescents.

The inner sides of the wings can hardly be described; they are beautifully mottled and variegated with black, brown, buff, steely blue, and other metallic tints; the ground colour is lighter than that on the outer side, the red and white markings of which gleam through like flashes of different coloured flame.

$\mathrm{Oh}$, a glorious fellow is the Red Admiral! and so bold and fearless, too, as an admiral should be; you may come close up to him as he sits sunning himself upon the flowers, and examine him at your leisure; but do not attempt to touch him, unless you really want a good specimen for your cabinet ; and even in that case, it is better, perhaps, not to risk the spoiling of these magnificent wings, but to search for a caterpillar: they are not difficult to find among the nettles where they feed. The colour is dusky green, with a yellow line running along each side; it is sparingly covered with short hairs, and its length varies from an inch and a quarter to one and three quarters; it often conceals itself by drawing together several of the nettle leaves by means of silken threads. 
When you have captured it, give it some of the seeded tops of the plants, for this is the part which it seems to prefer. By and by it will turn into a chrysalis of a greyish brown colour, having golden spots sprinkled over it; the back is rough and ridgy, the tail end sharply pointed, and the opposite end bearing a remarkable resemblance to the snout and head of a miniature pig.

It is generally at the latter end of August or beginning of September that this beautiful fly makes its appearance, in its new suit all fresh and glossy, and it generally disappears by the end of October; a few, it seems, manage to get into some snug hole or crevice, and live through the winter, coming out again for a short time in the spring, but with wings sadly rubbed and faded-insects which "have seen better days." Usually, however, the life of the gallant Admiral, is, as short as it is, no doubt, merry.

But why is it called Vanessa? why Atalanta? Let us see if we can find it out. The first you know is the generic name, and the genus to which it is applied, includes some of the most common, as well as the most beautiful of the British species; several of them we shall presently describe. Our business is now with the Red Admiral, or Alderman, as he is sometimes called, because, perhaps, aldermen once wore, and in some places still do wear, scarlet gowns edged with brown 
fur, making a mixture of colours something like the wings of this noble fly. But what about Vanessa? well, here again we are at fault; we can find no name, proper or common, no Greek or Latin root, at all like it, except vanesco-to vanish-in the Latin tongue, and therefore must give it up.

Atalanta I could tell a long story about, did I wish to entertain my young readers with old fables; she, too, according to mythological story, was one of the swift-footed, and did some very wonderful things, how many hundred years ago I am afraid to say; and now, that her name may not be clean forgotten, which I think it might just as well be, naturalists have bestowed it upon this gorgeous insect, although it appears quite a misnomer, as the Admiral is rather a heavy flyer for a Butterfly, and the English name which he bears is that of a gentleman, and not a lady.

All the flies of the Vanessa genus are remarkable for their robust bodies, and the thick texture of their wings ; they are strong and handsome, rather than light and elegant; that is, comparatively speaking, for lightness and elegance are inseparable from the whole race of diurnal Lepidoptera. 


\section{PEACOCK BUTTERFLY.}

PLATE II.-FIG. IV.

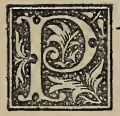

APILIO, or Vanessa Io. We have here another magnificent species, on which many of my readers must have often looked with intense admiration, for it is common enough throughout the greater part of England, especially in the more southern counties; it gets rare towards the north, and in Scotland is seldom found. Old writers called this Butterfly Omnium regina, that is the Latin for Queen of all, and we ourselves are half inclined to rank it before all others for beauty and richness of colouring.

It is scarcely so large as the Red Admiral, seldom measuring more than two inches and a half across the expanded wings, which are of a rich dark brownish red, the upper pair several shades lighter than the lower; at places there is an inclination towards a purple shade, and a large eye, or, as naturalists call it, an ocellus, from the Latin word oculus - an eye, covers a considerable portion of each of the four wings; being situated, in the upper pair, near the extremities farthest from the 
body, and in the lower, also near the tips and outer margins; these ocelli are much like the many-coloured spots on the tail of the peacock, and hence the insect has been named after the bird.

Io was the name of a heathen goddess, about whom there is told a cock-and-a-bull story, not worth repeating, more especially as we cannot learn that it has any relation to the habits or appearance of the insect to which the name is applied, and the under side of whose wings are very different from the outer, being of a uniform dark brown colour, traversed by black waving lines, which form a complete network, through which, like stars through a mist, the blue and white spots on the outer sides faintly peep. The body of this insect is blackish, clothed with rust-coloured hairs, and the legs are of a dull yellow colour.

The Caterpillar is also black, or nearly so, with numerous white points dispersed in rows across the body, which is partially covered with hairs; the legs are a rusty red. Its habits are gregarious, that is, numbers live and feed together; it feeds on two very common species of stinging nettle, amid which it may be found without much difficulty about July.

The chrysalis is, both in shape and colour, much like that of the Red Admiral ; there is something more of a green tinge in it, and the indentations along the back 


\section{Beautiful Butterflies.}

are deeper. The resemblance of the thicker end to the head of the swine is also more marked and distinct, and piggy here appears to be adorned with two stick-up ears, which is not quite in accordance with swinish fashion.

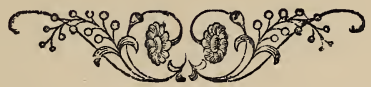




\section{LARGE TORTOISE-SHELL.}

PLATE III.-FIG. I.

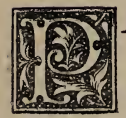

APILIO, or Vanessa Polychloros. The Tortoise-shell Butterfly is one of the commonest of our native species, but the Great Tortoiseshell, or Elm Butterfly, as it is sometimes called, must not be confounded with this; it is larger, handsomer, and also very much rarer; in the colours and markings of the two species there is not a great deal of difference; neither is there in the shape of their wings; the smaller is perhaps the more graceful of the two; the larger the more bold and noble-more rounded and full, and sturdy, so to speak, as though one were the personification-bless us, that is a long word-well, then, the figure, the showing forth of manly beauty, and the other of womanly loveliness. If we saw the two flying together, we might take them to be brother and sister, so great is the family likeness, and yet they are quite different species, although belonging to the same genus; and a naturalist would never take one for the other, however closely they might approach in size, as they sometimes do. Oh, these are sharp fellows, these naturalists; we sometimes fancy that they have micro- 
scopic eyes, that is, that they carry microscopes in their heads as well as in their pockets; they can detect such. minute points of difference, and so quickly too. They can see things that nobody else can see, and they tell such wonderful stories about the creatures that inhabit drops of water, and grains of sand, that one is at times inclined to think they have only been dreaming, and ought to begin their almost unbelievable stories with the line of the poet Coleridge-

\section{"In a vision once I saw."}

But then they tell us how we may convince ourselves of the truth of their statements, and bid us look through their glasses at some of the monsters of the invisible world, which are frightful enough in pictures; but all alive and kicking are, oh dear! enough to make a nervous person go clean out of his senses-"off his head," as they say in some parts of England.

One of these days I mean to write a little book for your instruction, all about the animalcules, and the uses of the microscope, and then we will get our engraver to serve you up such a dish, or rather a number of plates, of odd-shaped creatures, which inhabit the world out of sight, that if you won't be startled and surprised, that's a pity!

But what is our Vanessa Polychloros doing all this tirne? enjoying himself in the sunshine no doubt, 
like an idle fellow as he is, for the song says, you know that

"The Butterfly was a gentleman, Of no very good repute, And he roamed in the sunshine all day long, In his scarlet and purple suit."

There he goes fluttering, fluttering, with his gailypainted wings spread out, with the tips as much perhaps as three inches apart, without appearing in the least incommoded by the long name he carries about with him, and which, if he should let it fall so as to break it into two halves, would turn out to be made up of the Greek words Polus-many, and Chlorus-spot, so that it means, literally, many-spotted; and this we must confess to be a very appropriate title, better than all the Atalantas and Camillas, and such like proper, or rather improper, names of fabulous persons. It was most likely on a bright July day that the Great Tortoise-shell Butterfly-you know why he is called that, because he is marked like the shell of a tortoise-burst from his chrysalis prison, and he will most likely leave this gay and busy scene before the end of September; either dying, as is generally the case, or stowing himself away in some nook or cranny, where his superb wings can be kept dry for a little spring exercise, should the weather prove at all genial; they get, however, sadly rubbed and rumpled, and cannot be made 


\section{Beautiful Butterfies.}

to look like new by all the dyers and scourers in Butterfly land. I shall not attempt to describe these wings, for all my readers have seen the Small Tortoiseshell fly, and often enough to know every marking; should any of them unhappily belong to that class of persons who go about the world with their eyes shut, they can open them for once, and look at the beautiful pictures with which our artist has illustrated this volume, and they will see at a glance what it would take many words to express in a very imperfect manner. The under side of the wings is a dull brown, approaching to a black, with here and there a streak of blue, and waving lines of dusky white, and irregular bands of deeper colour.

The Caterpillar of this species may be found most usually on the leaves of the elm tree, where they feed, numbers of them together, under little silken tents, spun out of their own bodies; their colour is a bluishbrown, and along each side runs a broad band of orange, which, with numerous tufts of yellowish hair, gives thein quite a gay appearance. After the first change of skin they break up their family parties, and disperse to seek their livelihood singly; they are sometimes found on the willow and several kinds of fruit trees, especially the cherry.

The chrysalis is brownish flesh-colour, with golden 
spots. It has the peculiar conformation at one end mentioned in the two preceding species.

This butterfly is to be met with in all the southern counties in England; in some years it occurs in large numbers at particular places, but not so regularly as to be called a common fly anywhere in this country, where its near relative, the Small Tortoise-shell, is very abundant. 


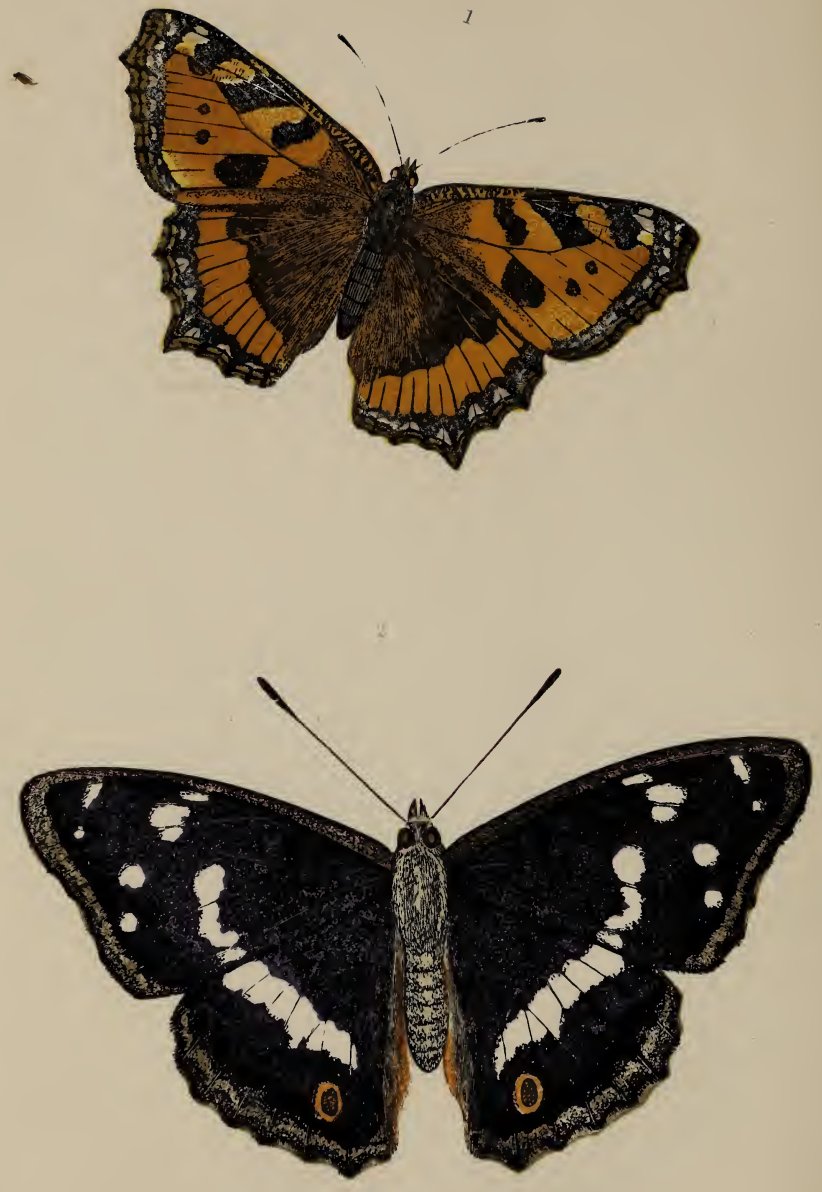

1. Small Tortoise-shell, 2. Purple Emperor. 


\section{SMALL TORTOISE-SHELL.}

PLATE IV.-FIG. I.

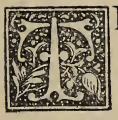

HIS is the Papilio, or Vanessa urtica of naturalists, and when $I$ tell my readers that the Latin for nettle is urtica, and that the Caterpillar feeds upon nettles, they will at once see the fitness of the title. This Caterpillar is found in the beginning of June, and again about the middle of August. In the early stages of its growth it is gregarious like the larva of the last species; the body is a dull greenish brown, with paler lines down the back and sides; the head black, as are also the tufts of hair; the chrysalis is brownish, and shaped much like that of the larger species. It is sometimes nearly covered with gilding, and is generally suspended by the smaller end.

Everywhere in this country, and throughout the whole of the summer, one sees the Little Tortoise-shell Butterfly, of which species there appears to be two goal deliveries in the year, one in June and the other in September, so that by the time one batch of released prisoners dies out another comes to take its place, and thus the summer sunshine glanceth ever upon Tortoiseshell wings, and frequently the spring sunshine too, for 


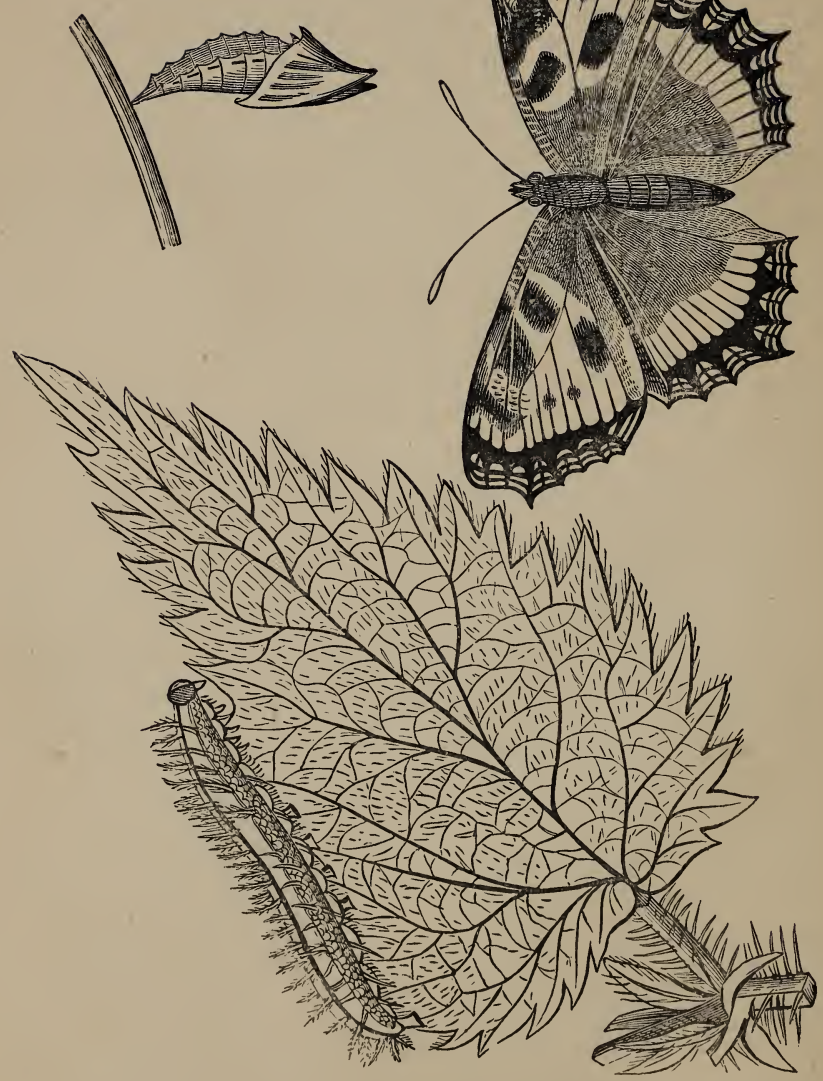

LARVA, CHRYSALIS, AND INSECT OF THE SMALL TORTOISE-SHELL BUTTERFLY. (Vanessa urtica.) 
more of this species than of any other manage to preserve life through the rigors of the winter, and they venture forth, when the blasting March gales have sunk to rest for a time, and the sun has melted the snow from off the hills, and the primrose blossoms and the violet buds are just beginning to unfold their fragrant petals in woods and on mossy hedge-row banks. But full often do they share the fate of the venturous insects described by the Peasant Poet of Northamptonshire, John Clare, who says-

"The Butterflies by eager hopes undone, Glad as a child, came out to meet the sun, Beneath the shadow of a sudden shower Are lost, nor see to-morrow's April flower."

The same poet, we remember, has another allusion to the Butterfly making its appearance in March, much to the delight of the old village dame; in this case, however, it is one of the white species spoken of, most likely the Common Cabbage Butterfly (Pontia brassica), which sometimes comes out very early.

"The old dame then oft stills her humming wheelWhen the bright sunbeams through the windows steal and gleam upon her face, and dancing fall In diamond shadows on the pictur'd wall; While the White Butterfly, as in amaze, Will settle on the glossy glass to gazeAnd, smiling, glad to see such things once more, Up she will get and totter to the door." 


\title{
CAMBERWELL BEAUTY.
}

\author{
PLATE III.-FIG. II.
}

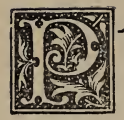

APILIO, or Venessa antiopa. This is the crowning glory of the British Butterfly collector's cabinet, and a happy man is he who gets a perfect specimen of an insect which is at once so rare and beautiful. It measures across the expanded wings from a little under to considerably over three inches,

- and is, therefore, one of the very largest of the native species, from all of which it differs greatly in shape, and still more in colour. Deep purplish-brown, of a rich velvety appearance, is the tint spread over nearly the whole upper surface of these wings; round the outer edges this colour deepens into a broad black band, which is ornamented with a row of violet blue spots, some of which are oblong, some of a crescent shape; attached to this band is what looks like a wide silken fringe, of a pale yellow or cream colour, slightly waved on the inner side, and sprinkled with little black dots at the angles; the top edges of the upper pair are slightly mottled with yellow, and on each, near the tip, are two spots of the same. Underneath the wings are a shining ashy brown, with a network of black waved 
lines all over them; the yellow spots, so distinct on the outer side, showing faintly through.

The Caterpillar is large and black, with red spots along the back, and reddish legs; it is thinly furnished with clusters of hairs ; it is gregarious, and feeds upon the leaves of the birch, willow, and poplar, and is said to be most usually found among the upper branches of these trees. The chrysalis is of a dull black colour, spotted with deep yellow, and of a very irregular shape. In neither the larva nor the pupa state has the insect been found, we believe, in this country, where its appearance occurs, except just here and there a single . specimen or two, at long and uncertain intervals. About eighty years ago it was seen in great numbers in many parts of the kingdom, and again in 1819, but not since then, although almost every year one or more specimens are taken or seen.

This fly obtained its common name from having been first observed in the neighbourhood of Camberwell, in the county of Surrey; it is also sometimes called the Grand Surprise, and the White Border. The scientific name will take us again among the heathen gods and goddesses. Antiope, we are told, was a daughter of Nycteas, king of Thebes, who went through a variety of strange adventures, of the account of which we can only say, that if it is altogether false, so much the better; for, little as we like story-telling, what this Antiope is 
said to have done we like far less. The fair Camberwell Beauty - the loveliest of British Butterflies-is by no means complimented in having such a name bestowed upon her.

We cannot refrain from quoting here a passage from a monthly publication called 'The Naturalist,' wherein this butterfly is very touchingly and pleasingly alluded to. Our young readers, we have no doubt, will fully enter into the feelings and associations there expressed:-

"It was on a summer evening, of early life, when little more than a child, in rambling through a wood on a holiday, my attention was drawn to a spray on which rested a Camberwell Beauty. I had never seen such perfection before. My eye rested on the rich dark velvety wings, fringed with ermine white, relieved by an inner border of metallic blue spots, like bracelets of lapis lazuli. At this moment I could mark the very spot in the forest where this vision was revealed, and well do I remember the thrill of delight with which I captured and carried off my prize in triumph, to exhibit before a little knot of schoolfellows. I can see their uplifted hands, I can hear their exclamations of surprise, as they beheld the splendid captive. I can recall their features and their forms as if now living, though every individual among them has long since been called away, and now possibly familiarised with 


\section{Beautiful Butterflies.}

greater things than it is permitted man's philosophy to dream of here.

"But to me, trifling as this little incident may appear to many, the results through life have been neither unimportant, useless, nor uninfluential; for it is to it I stand indebted for many a happy hour. That 'poor insect' awakened a taste which has never slumbered; and the cultivation of Natural History has been my solace in times and seasons, when the mind required something to fall back upon, apart from the business and pursuits of the world. It so happened that from the time I have alluded to until a few summers ago, in one of the mountain passes of the Pyrenees, I had never met with a single living specimen of Vanessa antiopa, when, on a lovely day, on a spray the very counterpart of that of the days of my childhood, I saw the expanded wings of this insect, and the days of 'auld lang syne,' which first introduced it to my notice, came across my mind vivid and clear as though but of yesterday. This summer, again (and not unfrequently) I fell in with this associate of my early years. Children, indeed, may they be called of the sun. In the hot and sultry hours of noonday, they would flit by, rendering it almost impossible to watch their course; if in these flights two or three met in the glade, they paused in their speed, and fluttering together, so busied themselves in conflict of rivalry or affection, I know not which, that I more 
than once caught two at a time, and after admiring them, in gratitude for the benefit $I$ had received at their hands, sent them forth once again to enjoy their summer revelries. At other times (I particularly recollect one occasion), in a wood on the summit of the Drachenfels, when the wind was rather keen, I found numbers resting on the backs of trees, in a state of stupor; they made no attempts to escape, and when thrown into the air their wings barely opened, or flapping feebly, eased their fall, or enabled them to seek repose on the stem of a rotten trunk."

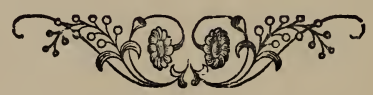





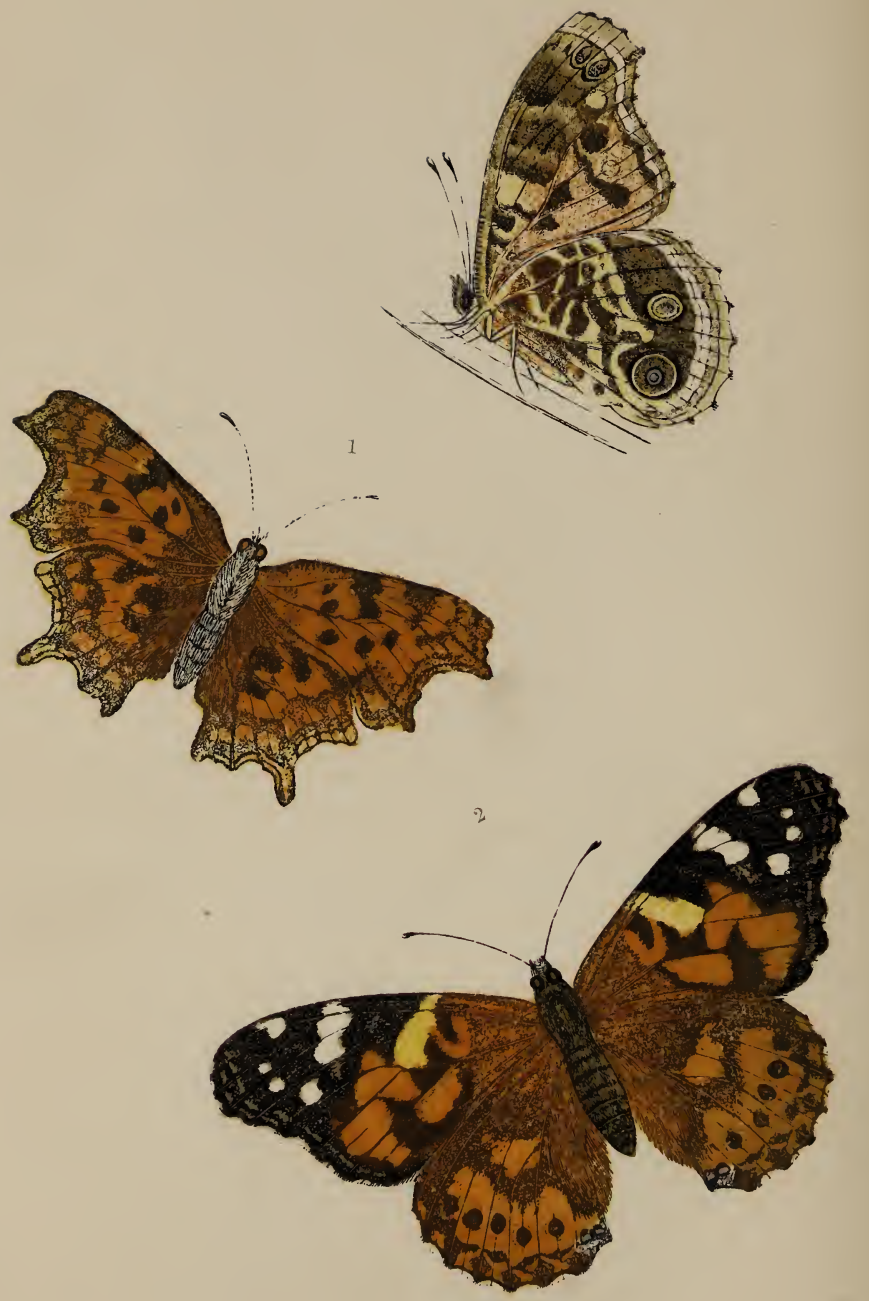

1. Comma Butterfly. 2. Pauted Lady. 3. Scarce Painted Lady. 


\title{
COMMA BUTTERFLY.
}

\author{
PLATE V.-FIG. I.
}

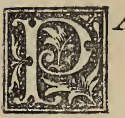

APILIO, or Vanessa C-album. This curious Butterfly is distinguished from all other British species, by the deeply cut or indented outline of the wings; which, forming the kind of curve presented by the stop called a comma, gave occasion for the name by which it is commonly known. Naturalists we find term it $C$-album, the latter term meaning white; because there is marked on the under side of each of the lower wings a letter $\mathrm{C}$ in white, as distinctly on some individuals as though it had been painted in. This is a very singular distinctive mark, the like of which is to be found, I believe, on no other member of the Butterfly tribe.

The Comma is the smallest species of the Vanessa genus which inhabits Britain, the utmost extent of the wings seldom exceeding two inches; in colour it closely resembles the Tortoise-shell Fly, being reddish brown and black; there is, however, less variety in the shades and markings. The under sides of the wings are in some instances elegantly variegated with brown and grey of various shades, and metallic green; in others 
they are of a uniform dull brown, which held in different lights has a bronzy appearance. There are two broods of this fly in the year, one coming out in June, and the other in August or September; and it has been observed that the wings of the latter brood are much less bright and various in colour than those of the former.

The Caterpillar, which feeds on the elm, willow, honeysuckle, hop, nettle, and several other plants, is of a reddish brown, rather thickly set with hairs, and having a curious hairy projection on each side of the head, which is nearly heart-shaped. The chrysalis is a pale dirty brown, spotted with gold; shaped much like those previously described.

This is by no means a common fly in this country, that is generally speaking, for in some years it occurs in great plenty. York, Worcester, Dorset, Warwick, Suffolk, Gloucester, Herts, and Middlesex are the English shires where it has been chiefly taken. Also in Fifeshire, in Scotland, but in no other part of that country, except, perhaps, some of the southern counties.

A celebrated entomologist named Westwood, has observed a great variety in the shape of the wings of this insect, some not being nearly so deeply indented as others; so that there are Common Butterflies, the outlines of whose wings present rather the form of a 


\section{Beautiful Butterfies.}

note of interrogation, (?) as though they would bid the student in entomology to pause and ask himself, can it be a Comma or some other species; and so perhaps bring him to a semicolon, (;) or a colon, (:) or even a full stop. (.) While struck with the beauty of the insect, he will, it is likely, utter a note of admiration. (!) 


\section{PAINTED LADY.}

PLATE V.-FIG. II.

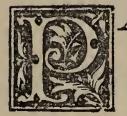

APILIO, or Cynthia cardui. The genus Cynthia into which we now pass, so closely resembles the Vanessa that it is considered by some naturalists as only a sub-genus or kind of lesser division thereof. Cynthia is a name sometimes applied to the moon, as it was to one of the fabled goddesses of the Grecian mythology, between whom and that enlightener of the night, there was supposed to be some mysterious kind of relationship. We have only two Cynthias in Britain, and one of these can hardly be called a native species, but a single specimen, I believe, having been taken in this country; of this I shall presently speak. Now let us examine into the merits of the Common Painted Lady, which is a truly beautiful fly, graceful in form, and harmonious, if not brilliant, in colouring. A reference to the plate will show this better than any description, as far as the general shape and outer side of the wings are concerned; but a chief beauty of this fly consists in the marking of 
the under side, which looks like an exquisite piece of mosaic or inlaid work, in which the several pieces of red, orange, buff, olive, brown of various shades, black, and white, are nicely fitted in to form a diversified pattern, with small white veins dividing the compartments. Near the outer edge of the under pair is a row of four or five round spots, encircled with rings, so that they resemble eyes: on a close examination it will be seen that two of these are powdered in the centre with green, and two with blue. Between these and the edge of the wing is a row of small purple crescentshaped spots. Over the whole of the under side of the upper pair is spread a delicate crimson flash, like that which tells the approaching dawn of a summer's day. The body of the insect is clothed with reddish brown hairs above, and white beneath.

The Caterpillar, which is found generally in July, is of a reddish brown colour, with interrupted yellow lines along the sides; it is pretty thickly covered with hairs. It feeds upon thistles, nettles, mallows, artichokes, and several other plants, and lives singly. The chrysalis is light brown, with ash-coloured lines and golden spots; it is of an irregular angular shape.

The expanded wings of this insect sometimes measure two inches and three quarters across. It is generally somewhat scarce in England, although it occasionally occurs in great abundance; in the year 1828 
there passed over Switzerland a vast swarm of these flies, occupying several hours in the transit; two years previous to this the species was very abundant near London; it has been found in Ireland, and the more southerly of the Scottish counties.

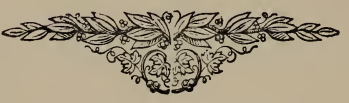




\section{SCARCE PAINTED LADY}

\section{PLATE V.-FIG. III.}

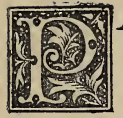

APILIO, or Cynthia Huntera. Of this fly but one specimen is recorded to have been taken in Great Britain, and that was at Withybush, near Haverfordwest, South Wales, in the midsummer of 1828. It was thought to be but a variety of the common kind, but afterwards discovered to belong to a distinct species, occasionally plentiful in America, where it is said the Caterpillar is found about the end of the months of April and July, there being two broods in a year. It measures about two inches and a quarter across the expanse of the wings, which both in colour and shape are much like those of the $C$. cardui. We should have explained, by the way, that this word means a thistle.

The wild balsam and a kind of cudweed, called the obtuse-leaved, are said to be the food of this species in the larva state. Authorities differ as to the colour of its Caterpillar; its chrysalis we are told is "placed in the leaves of plants folded up and spun together," so says the Rev. F. O. Morris, in his beautiful work on 'British Butterflies.' 
96

Beautiful Butterfies.

The markings on the under sides of the wings of this insect are yet more elegant and delicate than those of the last; there is also somewhat more grace and beauty in those of the upper surfaces, as will be seen by a reference to the plate. 


\section{PURPLE EMPEROR.}

PLATE IV.-FIG. II.

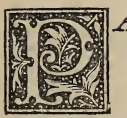

APILIO, or Apatura Iris. Ever has purple been the imperial colour, that of the robes of kings and emperors, and altogether great persons, there is a fitness therefore in the name of this king of British Butterflies, than whose wings no colour more rich and magnificent ever decked the shoulders of the mightiest monarch upon earth. To see these wings in perfection, it must be in the broad sunshine, and rather at a side-angle of the vision than looking directly at them ; in any other than a strong light they appear dull and lustreless-a rusty, dingy, brownish black, with just a tinge of purple, and no more; but even then it appears a noble fly-stout-bodied and strong-winged, with a flight like that of a bird, far up amid and above the topmost branches of the loftiest trees; there it flies, and there it sits on some projecting spray in right royal state, and where is the puny entomologist that with rod and net shall reach it down from thence? But sometimes it descends from these elevated positions to sail majestically amid the glades and along the wood-side hedge-rows, and then is the time of 
danger to liberty and life. Mr. Morris tells us of one collector who stated that he took as many as one hundred specimens in the county of Essex in a fortnight! What an arch regicide he must have been. Who ever heard of such a king-killer as this? One hundred crowned heads in a fortnight! Here was a wardrobe! ten times ten sets of royal robes. Bah! we do not like to think about it; so many beautiful insects deprived of life; so many bright flutterers stopped in the mid career of their enjoyment, for what? to satisfy a mania, as in too many instances the entomological furor may truly be called. May be he did it for profit; he dealt in Butterflies, and so depopulated the glades of Emperors to increase the value of his stock-in-trade. Well, we scarcely know that any valid objection can be offered to this; all we can say is, that we hope no such necessity for obtaining a livelihood will ever be laid upon us. We would not have such an amount of insect slaughter upon our consciences for all the Butterflies in the British Museum, much as we should delight in the possession of a good collection of these most beautiful of the works of the Almighty Creator.

The scientific name of this fly is a bit of puzzle. Apatao, in Greek, means I cheat, trick, or beguile; hence Apaturia was the name of a festival at Athens, instituted in remembrance of a stratagem, by which 


\section{Beautiful Butterfies.}

one king, who had challenged another to fight, put his opponent off his guard, and so killed him. One of the names of Jupiter we learn was Apatenor-the deceiver, and Apate is by one Greek author, applied to a plant. What connection, real or supposed, there is between all this and the generic name of our splendid Emperor we cannot imagine.

With the specific name Iris we have no such diffculty. In the mythology the messenger of the gods was called by this name, and the rainbow, more poetically than truthfully supposed to be her pathway from the regions above to earth, was also so termed; hence the word Iris came to signify that which was rich and various in colour, especially such as shifted and changed in different lights, or as we should say was iridescent. The rich purple flag-flower we call an iris, and so do naturalists term this glorious fly, whose dark wings are so richly overspread with purple down, and which is that well described by a British entomologist named Haworth.

"The Purple Emperor of the British oaks, is not undeservedly the greatest favourite of our English aureleans (Butterflies of which the chrysalis are marked with gold). In his manners likewise, as well as in the varying lustre of his purple plumes, he possesses the strongest claims to their particular attention. In the month of July, he wakes in the winged state, and 
invariably fixes his throne upon the summit of a lofty oak, from the outmost sprigs of which, in sunny days, he performs his aerial excursions; when the sun is at the meridian, his loftiest flights take place, and about four in the afternoon he assumes his station of repose. $\mathrm{He}$ ascends to a much greater elevation than any other insect, sometimes mounting higher than the eye can follow; especially if he happens to quarrel with another Emperor, the monarch of some neighbouring oak; they never meet without a battle, flying upwards all the while, and combating with each other as much as possible; after which they will frequently return again to the identical sprigs whence they ascended. The wings of this fine species are of a stronger texture than those of any other in Britain, and more calculated for that gay and powerful flight which is so much admired by entomologists.

"The females, like those of many other species, are very rarely seen on the wing; in three days I captured twenty-three (another regicide), nine of them in one day, and never took a female at all. The males are only to be taken with a long net, fixed at the end of a rod twenty or thirty feet long. There have been instances, though rare, of their settling on the ground near puddles of water, and being taken there. When the Purple Emperor is within reach, no fly is more easily taken; for he is so very bold and fearless, that he- 
will not move from his settling-place until you quite push him off; you may even tip the end of his wings, and be suffered to strike him again."

Here is the character of his majesty given with great truth and freedom; he is somewhat quarrelsome, it appears, as kings are apt to be ; jealous of any intrusion upon his own territories. A bold proud insect, this Purple High-flier, as he is sometimes called, you see him there in the picture the size of life, and very lifelike he looks, with the white patches beautifully relieving the otherwise heavy richness of his dark velvety wings, of which if you were to see the underside, a very different view would be presented; silvery grey, tawny orange, white and black, are there the principal colours, here fading off one into the other, there exhibiting strong contrasts and striking changes of hue. The Caterpillar and Chrysalis of this species are both green, of a fresh vivid tint; the former is marked with pale yellow lines; it swells considerably at the middle of the body, and tapers off at the tail to a point; it is not hairy, and the head is black, with a couple of projec tions like horns sticking straight up, which gives it a very singular appearance. It may be found about the end of May, feeding on the broad-leaved sallow and oak.

The Purple Emperor is chiefly confined to the southern counties of England; we do not hear of its 
being taken at all in the north. Yorkshire, Warwickshire, Hampshire, Northamptonshire, Middlesex, Suffolk, Surrey, Sussex, Kent, and Essex, are those divisions of the country where it has been chiefly captured; sometimes, as we have already shown, in great numbers : so that it can scarcely be called a rare fly. In several of the Kentish woods, not far from where this little book is written, it may be found at the proper season, but generally flying high out of the reach of the net, so that the captures are not numerous; the chrysalides are occasionally found, and the Caterpillars sometimes, but very rarely. 


\section{Beautiful Butterflies}

\section{BROWN HAIRSTREAK.}

PLATE VIII.-FIG. 1 .

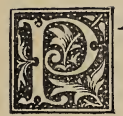

APILIO, or Thecla Betula is the scientific name of this insect, which is the largest of the five British species contained in the genus Thecla - a pretty little family group, by no means remarkable for brilliancy of colour, the upper side of the wings being mostly brown; the under sides, however, are beautifully marked and pencilled with delicate wavy lines, like hair, hence the name Hairstreak, and spots and bands of yellow and white.

One species has the under side nearly all green, on another is a zigzag mark like the letter $\mathrm{W}$; on one the wings approach nearly to a black, and one has a fine purple reflection playing over the brown ground colour. And so we have Purple, Green, White-W, Black, and Brown Hairstreak Butterflies, all of which have a little spike-like lengthening of the lower wings, which distinguishes them from the Argus, and most of the other smaller British flies.

The specific name Betula, given to the Brown Hairstreak, has reference to the food of the Caterpillar; 
Betula, in Latin, signifying a birch tree. This species is not very common in England ; it generally makes its appearance about the end of August or beginning of September, and may be taken mostly near oak or beech trees.

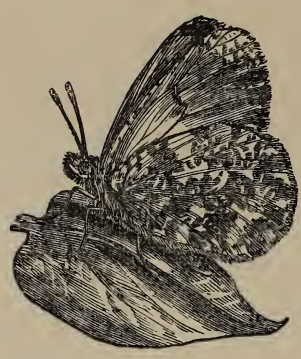




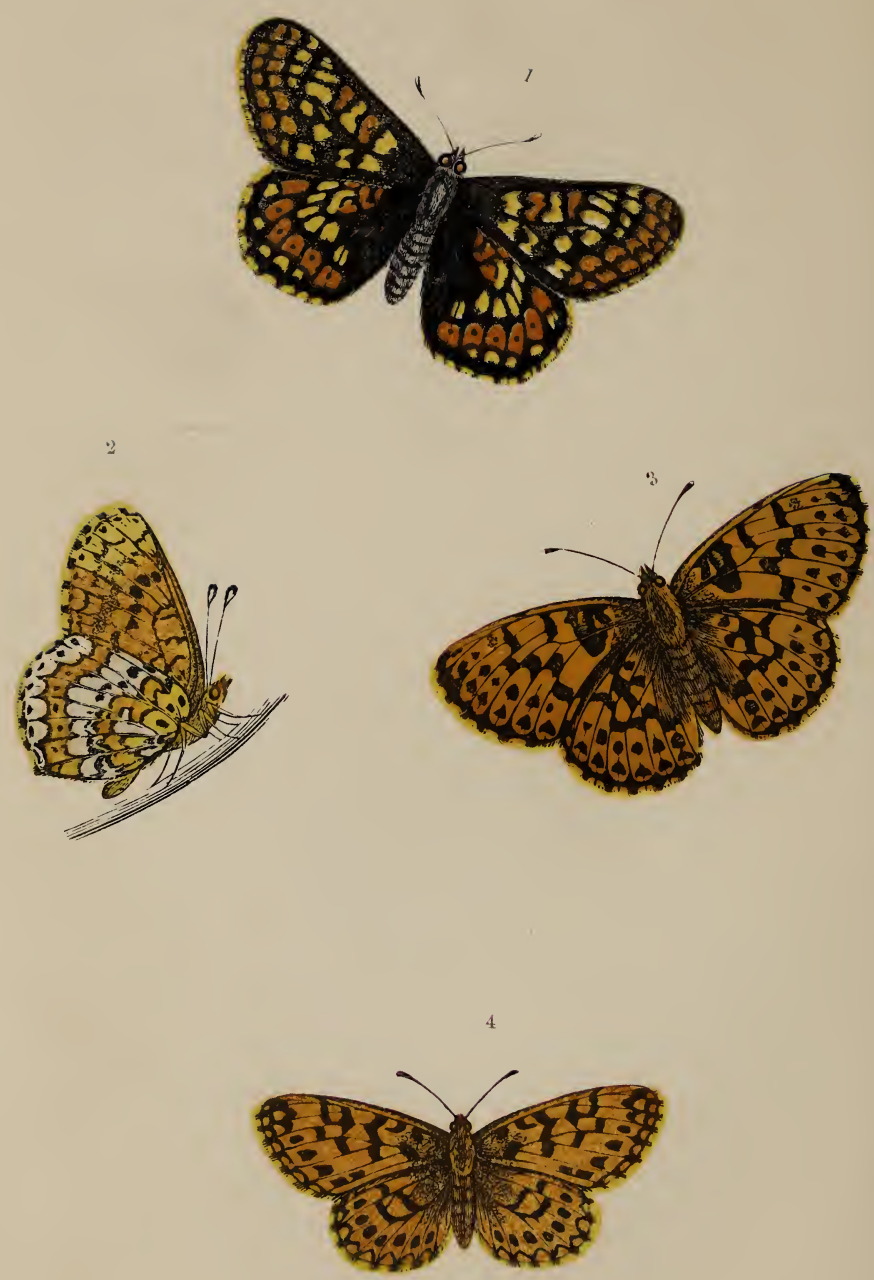

1. Greasy Fritillary. 2. Glanville Fritillary. 3. Peari-bordered Fritillary. 4. Weaver's Fritillary. 


\section{GREASY FRITILLARY.}

Plate VI.-FIG. I.

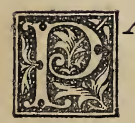

APILIO, or Melitoe artemis. The Fritillaries, although by no means the gayest in colour, are among the most beautifully marked of our native Butterflies; there are as many as twelve different species of them, five or six of which only bear the generic name Melitcea, derived, it may be, from the Latin Milites, a precious, stone, of an orange colourthat tint prevailing more or less in all Butterflies belonging to this genus. Artemis occurs in the mythology as the name of a Greek goddess. Artemesia is found in ancient history several times; it is also the name of an extensive genus of plants, mostly remarkable for their bitterness, such as wormwood and southernwood, none of which, however, appear to be the common food of the Caterpillars of these elegant flies ; that of the Greasy, or, as it is sometimes called, the Marsh Fritillary, feeding on the plantain and the scabious. The first of these names is derived from the peculiar shining appearance of the under side of the 
fore wings, which look as if they had been oiled; the last from the moist marshy places in which the fly is mostly found. It is generally first on the wing about the middle of May, and may be seen as late as that of July, chiefly in the southern counties of England, but sometimes as far north as Durham and Northumberland.

In Sussex, about Brighton; and Berks, about Enborne, it is said to be particularly plentiful. It measures across the extended wings from an inch and a half to two inches; these wings are of a reddish orange colour, crossed with wavy lines of black, and variegated with patches and spots of delicate straw-colour; the upper and under pair are much alike in their markings; they generally have a dark brown border, and a fringe of silky grey for edging; the under sides are of lighter colours-cream, straw, and silvery grey, with the black lines showing through, and little eyes peeping out here and there, and small crescent-like spangles, and faint waves like clear water or curling smoke, making the prettiest variety that can be imagined.

The Caterpillar is hairy, black above and yellow beneath, with a line of small white dots along the back, and another on each side: it has reddish legs.

The chrysalis is dingy white, with brown spots and 
markings; it is generally suspended between several blades of grass, drawn together and fastened at the top. It is not so irregular in shape as many before described, nor is it marked with gold

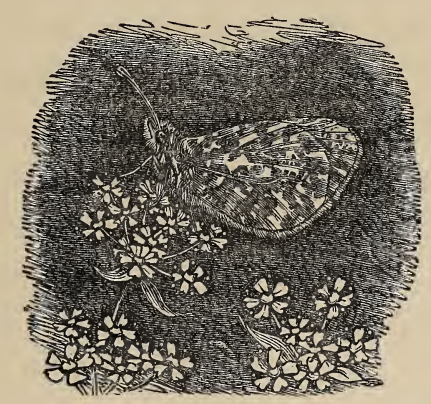




\section{GLANVILLE FRITILLARY.}

PLATE VI.-FIG. II.

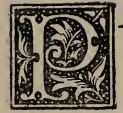

APILIO, or Melitcea Cinxia. This, although not uncommon on the continent of Europe, is a rare fly in the British Islands. It has been found most plentifully amid the romantic glens and seaward-sloping hills in the Isle of Wight; also in Kent, near Dover and Dartford ; and in the counties of Yorkshire, Warwickshire, Lincolnshire, and Wiltshire. May, June, and July are the months in which it may be looked for. It closely resembles the species last described in size and shape, but is somewhat different in colour, and in the arrangement of the markings; the cross lines are more regular, and beautifully waved, and the spots more numerous and distinct; the under sides of the wings are paler, having much of pale straw-colour, the black veins and spots of the upper side being clearly visible.

The Caterpillar of this species is black; it is faintly spotted with white, and has a red head and legs. It feeds on such wild plants as the narrow-leaved plantain, hawkweed, and common speedwell. An English entomologist, named Westwood, says that "these 
Caterpillars are found in the autumn living in societies under a kind of tent formed by drawing together the tops of the leaves on which they feed, and covering them with a web."

The chrysalis is pale brown, spotted with orange; in shape much like that of the last species. It is always suspended by the tail end.

The specific name Cinxia probably comes from the Latin Cinctus - a girdle, having reference to the band-

- like markings of the wings of the perfect insect, the white dots on the larva, or the row of raised orange spots on the pupa case. 


\section{PEARL-BORDERED FRITILLARY.}

PLATE VI.-FIG. III.

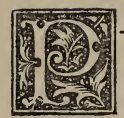

APILIO, or Melitoea Euphrosyne. This is a very beautiful little fly, although it has not much variety of colour : its markings are very regular, or what we should call symmetrical, that is, having a certain accordance or agreement with each other; veins, and spots, and crescents, and dashes of black, upon a deep orange ground, all as regular and even as though they had been traced out by means of rule and compass, and then carefully filled in by a very steady and practised hand, and all round the outer edge runs what seems to be a silken string of tiny pearls. It is indeed an exceedingly pretty fly, with its under wings like embroidered satin of yellow and pale brown, with the faintest flush of red, all so curiously marked, and veined, and mottled. You may see it flitting about towards the end of May, and again quite late in the autumn, when it appears that a second brood issues from their prisons, the shape and colour of which have not been exactly ascertained, to sport awhile in the sunshine, spreading their wings to the extent of 
perhaps two inches across, although more frequently an inch and a half is the utmost reach of the downy membranes. This fly may be found in most parts of England, as well as Scotland; it is by no means a rare species, although not so common as many.

The Caterpillar feeds on the leaves of different species of violet. It is black and hairy, with a double row of orange spots along the back.

The specific name Euphrosyne, carries us again to the ancient mythology, where we find it applied to one of three sisters, so beautiful that they were termed the Graces.

Fair and graceful they might be,

Stepping lightly as a fairy;

But they could not sport like thee

In the sunshine-Fritillary!

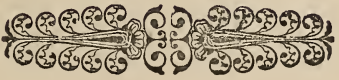




\title{
WEAVER'S FRITILLARY.
}

\author{
PLATE VI.-FIG. IV.
}

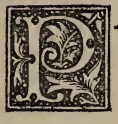
APILIO, or Melitcea dea. This it will be seen is a smaller fly than the species last described; it is also much rarer, only a few specimens having been taken in this country: the first of these to which the attention of scientific entomologists was called, was captured in Sutton Park, near Tamworth, in Staffordshire, by a Mr. Weaver, by whose name the insect was called. It is a remarkably elegant little fly, resembling closely in its tints and markings Miss Euphrosyne, to whom we have just dedicated a line or two.

The Caterpillar, which is dark-coloured and hairy, feeds upon the leaves of the sweet violet; the chrysalis has not been described, probably because not found by a British Naturalist. There are said to be two broods in the year.

The specific name seems to come from the Latin $d i$ or dis, meaning something which differs from another, as this fly does, although but slightly, from the better known preceding species. 


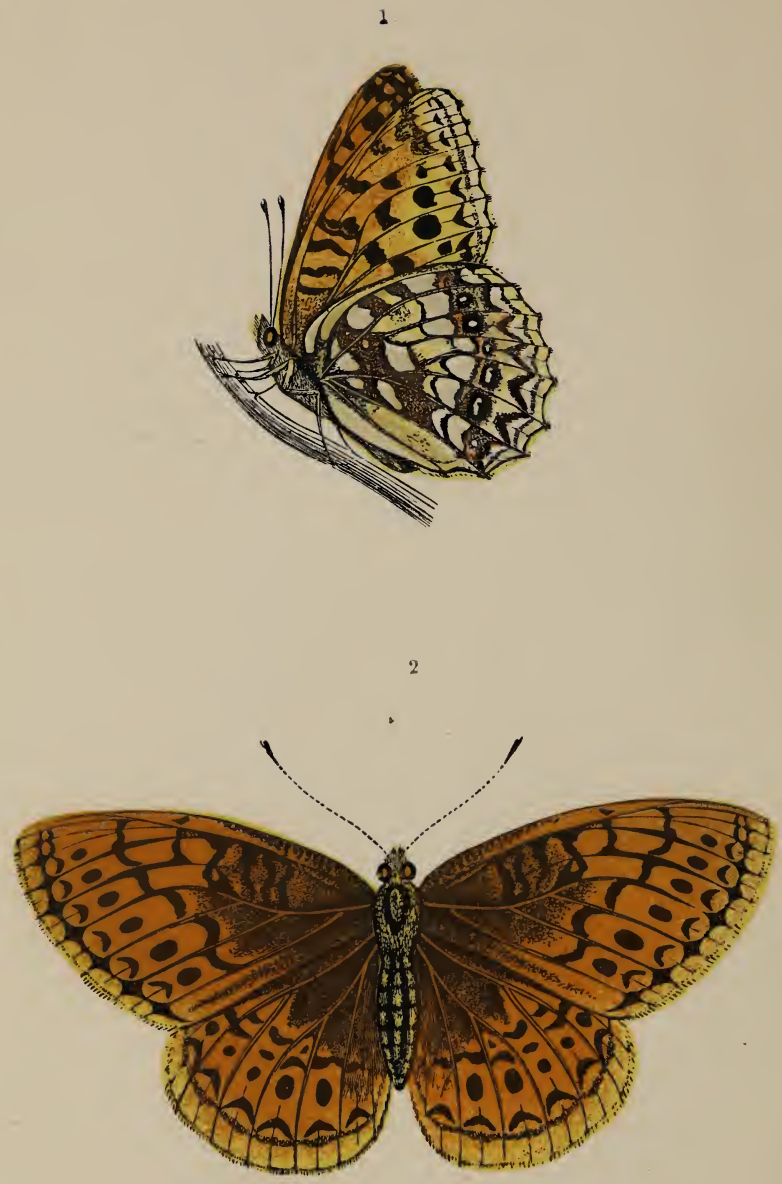

1. Brown Fritillary. 2. Venus Fritillary. 


\section{HIGH BROWN FRITILLARY}

PLATE VII.-FIG. I.

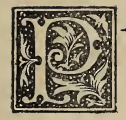

APILIO, or Argynnis adippe. There are but five species of British Butterflies included in the genus Argynnis; these are all Fritillaries, and are the largest and most richly ornamented of that family group; the generic name comes, no doubt, from the Latin word argent-silver, as these flies are especially remarkable for the large spots and streaks of beautiful silvery white with which the under sides of the wings are decorated.

The High Brown is a fine species of Fritillary, measuring as much as two inches and a half across the expanded wings. It is found in considerable numbers in most of the southern counties of England, and has been taken as far north as Nottinghamshire. It appears about the end of June, or beginning of July; and commonly frequents heaths and the borders of woods.

The upper side of the wings is a rich red brown, with a greenish tinge at the base, that is, where they are united to the body, which is also red brown. Lines, and dots, and crescent-shaped waves of black, arranged with the utmost regularity, give to the whole a tesse- 
lated or chequered appearance, as though it were a piece of inlaid work. We have in this country a wild plant-a kind of lily-the leaves of whose fleshcoloured blossoms are in like manner chequered with black spots; the old English name of this plant is Fritillary, and in the resemblance, real or fancied, of its blossoms to the wings of the Butterflies so called, originated their family title.

The Caterpillar of this species feeds upon the leaves of the sweet violet, and upon those of its near relative the pansy; no doubt also upon several other plants, although this has not been clearly ascertained. It is of a reddish colour at first, but turns to olive green after the first or second change of skin; it has an interrupted white line along the back, and a row of longish white spots on each side. It is hairy, but not very thickly covered.

The chrysalis is of a reddish colour, with silvery spots; the insect remains in this stage of its existence about a fortnight.

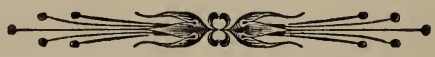




\section{VENUS FRITILLARY.}

PLATE VII.-FIG. II.

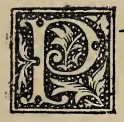

APILIO, or Argynnis Aphrodite. This is at once the rarest and most beautiful of all the Fritillaries with which we are acquainted, and the name of the ancient goddess of love and beauty has therefore been bestowed upon it. Aphrodite is but another title of that fabulous personage ; it comes from a Greek word signifying froth, because she is said to have been born of the froth of the ocean-a frothy kind of story altogether, and the sooner it is blown away by the wind of truth the better.

Of this Venus among Butterflies, which is properly an American species, but a single specimen appears to have been taken in England, and that was captured in the summer of 1833, in Upton Wood, a few miles from Leamington, Warwickshire. The lucky captor was James Walhouse, Esq.; so says Mr. Morris, in whose large and magnificent volume on 'British Butterflies' will be found depicted the under sides of the wings of this lovely visitant from the "far west;" here is his description of them, as far as words can describe such fair and delicate pieces of Almighty workmanship:- 
"Underneath, the ground colour is buff, tinged with pink, the tips greenish, the dark marks showing through. The hind wings are bronze green, but dark at their base, and lighter towards the outside; a row of semicircular silver spots follows the margin, and there are numerous other silver spots."

Of the Caterpillar and Chrysalis of this species, nothing seems to be known. The figure in the plate is the size of life; its elegance of shape, beauty of markings, and rich, harmonious tone of colour all must admire. 

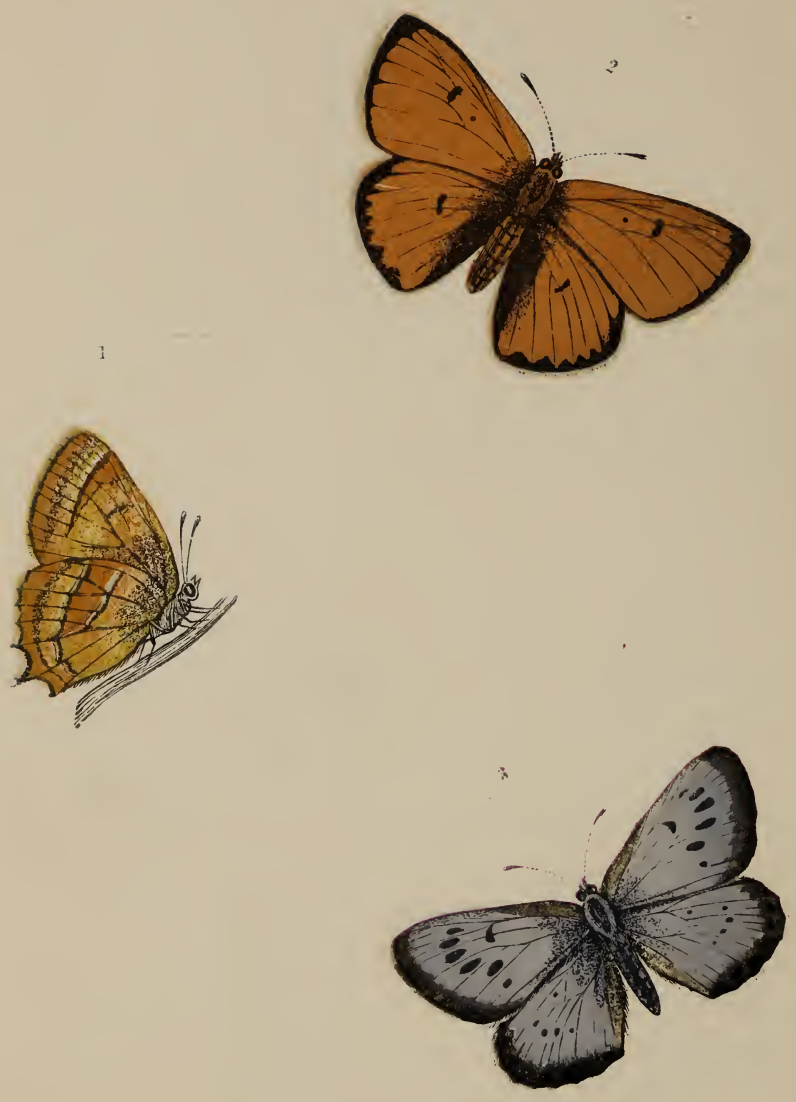

1 Brown Harstreak.

2. Large Copper.

3. Large Blue. 


\section{LARGE COPPER.}

PLATE VIIL.-FIG. II.

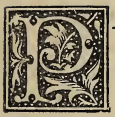

APILIO, or Lycana dispar. There are five species of Copper Butterflies, so called from the brilliant coppery hue of the wings, known in Britain, but only two that can be called at all common; indeed, perhaps only one, for the above-named species, since the draining and cultivation of the fenny districts of Cambridge and Huntingdonshire, Norfolk and Suffolk, its favourite places of resort, has in a great measure disappeared.

This fly, the largest of its genus, is remarkable for the flashing appearance of its burnished wings, which measure about an inch and a half across; it flits about among the reeds of the fens and marshes, and sports amidst the rank vegetation of the moist waste lands like a gleam of red fire; when at rest it presents a very different aspect, pale orange and blue ashy grey being the colour of the under sides of the wings; these are diversified with spots of black, encircled with yellow rings and veins, and crescent-shaped marks of the same dark colour. In this $\mathrm{fly}$, as in many other members of 
the Lepidopterous order, there is a marked difference. between the male and female; the latter is considerably the longest, and instead of the wings being entirely of a bright copper colour, except just a narrow black margin and a small, irregularly-shaped spot on each, they are covered with dusky black at the bases, and have wide margins, and many large spots of the same, which greatly detract from the brilliant appearance of the insect.

The Caterpillar is short and thick, swelling up in the middle, and tapering off to a point at each end ; the colour is bright green, with a dark line along each side, and little dots like a white powder sprinkled all over it. The food to which it is most partial is a kind of waterdock. The chrysalis, according to Mr. J. F. Stephens, " is at first green, then pale ash-coloured with a black dorsal (that is, back) line, and two abbreviated (shortened) white ones on each side; in shape it bears a close resemblance to a shell twisted and pointed at one end and open at the other."

Curtis says of this splendid fly that "it was first discovered in Wales by the celebrated botanist Hudson; it has since been captured in considerable abundance in Wittlesea Mere, Huntingdonshire. July is undoubtedly the right season for this insect, although it is met with in the beginning of August, flying among reeds about the centre of the Mere near Yaxley; it is very active, 


\section{Beautiful Butterflies.}

and in windy weather conceals itself amongst the highest reeds. Upon these the Caterpillar probably feeds, as the Butterfly has been found upon them just emerged from the chrysalis drying its wings."

The origin of the generic name Lycana is somewhat doubtful ; dispar, in Latin, means unlike, unequal, and may probably refer to the disparity of the male and female of this species. 


\section{LARGE BLUE.}

PLATE VIII.-FIG. III.

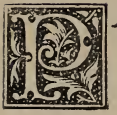

APILIO, or Polyommatus Arion. The little Blue Butterflies, of which there are as many as nine different species in Britain, must have been observed by most of my readers; they all belong to the genus Polyommatus, which word comes from the Greek, and signifies many-eyed; and they are so called on account of the numerous ring-encircled spots resembling eyes, which their wings, especially the under sides, present.

This species is considerably the largest of these pretty flutterers, sometimes measuring as much as an inch and a half or three quarters across the wings, which are of a delicate lilac-shaded blue, having a border of black, as if the fly had gone into mourning for a deceased friend or relative, and just a narrow edging of white, which beautifully relieves the otherwise sombre hue of the whole. The under sides of the wings are a brownishgrey, becoming more blue towards the base. As many as fifty of the black spots, of different shapes and sizes, may sometimes be counted on two wings only. 
It is not a common species in England, although it sometimes occurs in particular localities in considerable numbers. Kent, Wilts, Somerset, Bedford, Hants, and Northampton, are the English counties in which it has been captured, as well as in North Wales. The specific name Arion is one which occurs in the mythology as that of a celebrated poet and musician, who so delighted the dolphins with his harmony, that when he threw himself into the sea one of them became his horse, and brought him safely to land-very like a whale!

I have now introduced you to one, at least, in several instances to many, of the most remarkable members of the different genera of the Diurnal Lepidoptera, in which British species are included; there is one genus, however, which has no representative in this parliament of Butterflies. This is the Skipper genus, called, in scientific language, Hesperia, probably from Hesperus, the evening star; they are all small brown, or orangecoloured flies, variously chequered and marked; there are seven British species, mostly found in and about woods. The genera Pontia and Mancipium are likewise unrepresented here; to the former belong the white flies, which are so common at certain seasons of the year. The wings of some of these are delicately veined with black, and sometimes with green, and they are all worthy of a close inspection. In the latter genus we find the pretty Orange 'Tip, the Large Black-Veined or 
Hawthorn Butterfly, and several other elegant species, the names of which will be found in the following list, containing those of all the kinds known to be British. It is our purpose, in a future volume, to give a similar list of the Nocturnal and Crepuscular Lepidoptera, that is, the Moths of this country, with illustrations of the most beautiful and remarkable species. Foreign Butterflies and Moths will also form the subjects of two other volumes, so that four of them will contain a tolerably comprehensive account of the great Lepidopterous family, and induce, as we hope, many young readers to pursue the study of entomology in a regular and scientific manner. We wish these little books to be regarded as so many ornamented doorways, leading into the great temple of nature; and we would invite students to pass through and examine the wonders and beauties which lie beyond, praising God the while for the wisdom and goodness displayed in all His works, so various and so wonderful.

The study of insects has sometimes been objected to as trifling and frivolous, but no careful examination of aught which has been created by the hand of the Almighty can be so; and the smaller the creatures examined, the more striking are the proofs which we meet with of the exercise of a power and a skill such as man never possessed. 


\section{Beautiful Butterfies.}

\section{Let us, then, say with Cowper-}

"How sweet to muse upon His skill displayed, (Infinite skill!) in all that $\mathrm{He}$ has made;

To trace in Nature's most minute design

The signature and stamp of Power Divine;

Contrivance exquisite expressed with ease,

Where unassisted sight no beauty sees;

The shapely limb and lubricated joint,

Within the small dimensions of a point:

Muscle and nerve miraculously spun;

His mighty work who speaks, and it is done:

The invisible in things scarce seen revealed;

To whom an atom is an ample field."

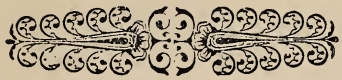





\section{LIST OF SPECIES.}



Beautiful Butterfies.

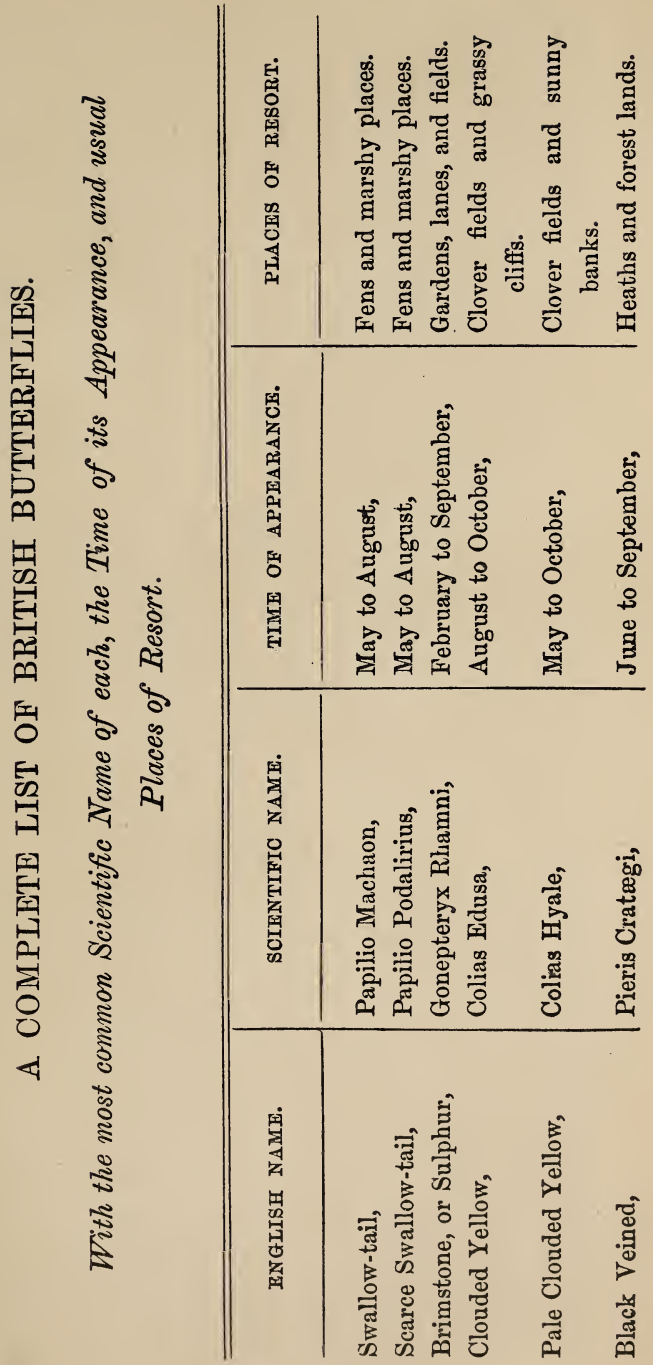




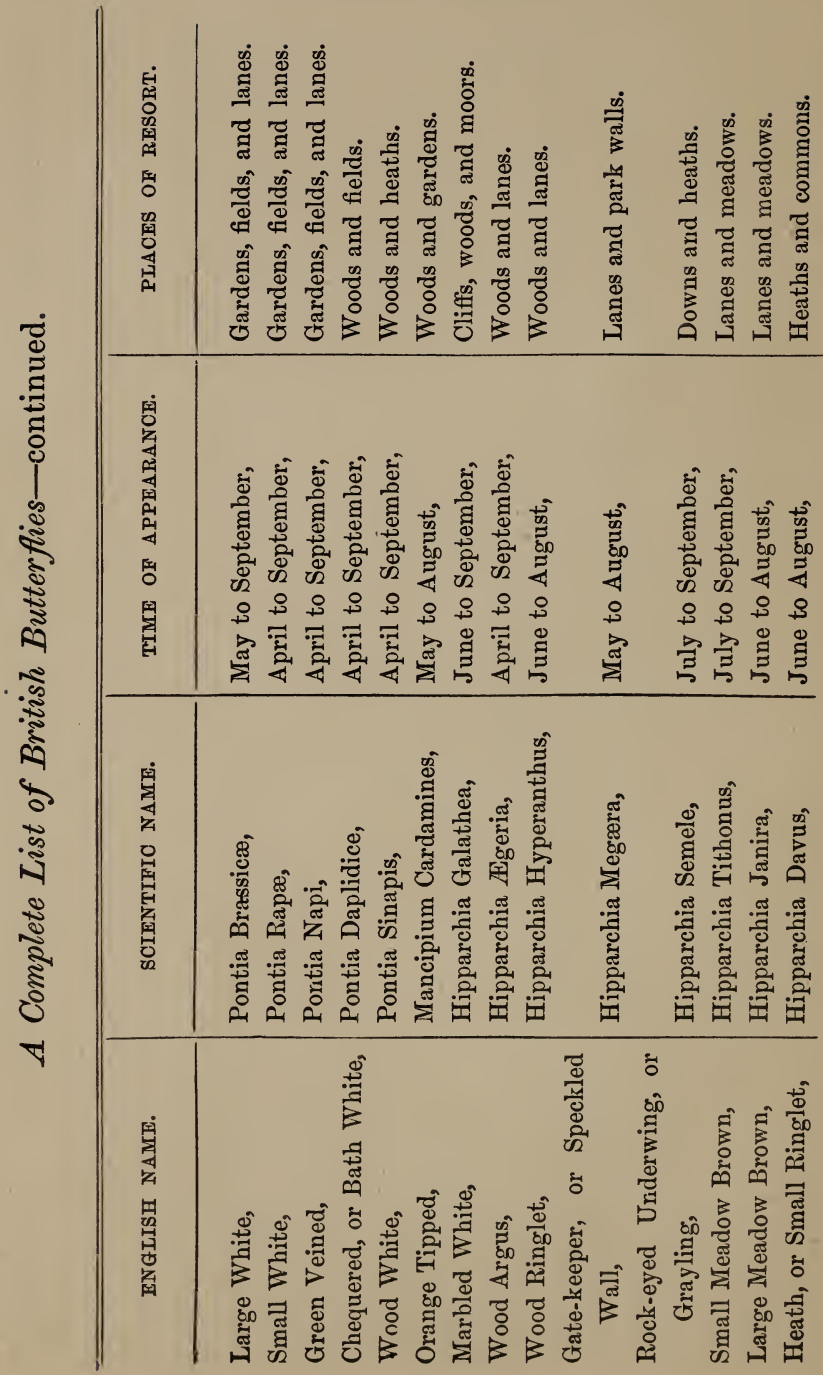


Beautiful Butterflies.

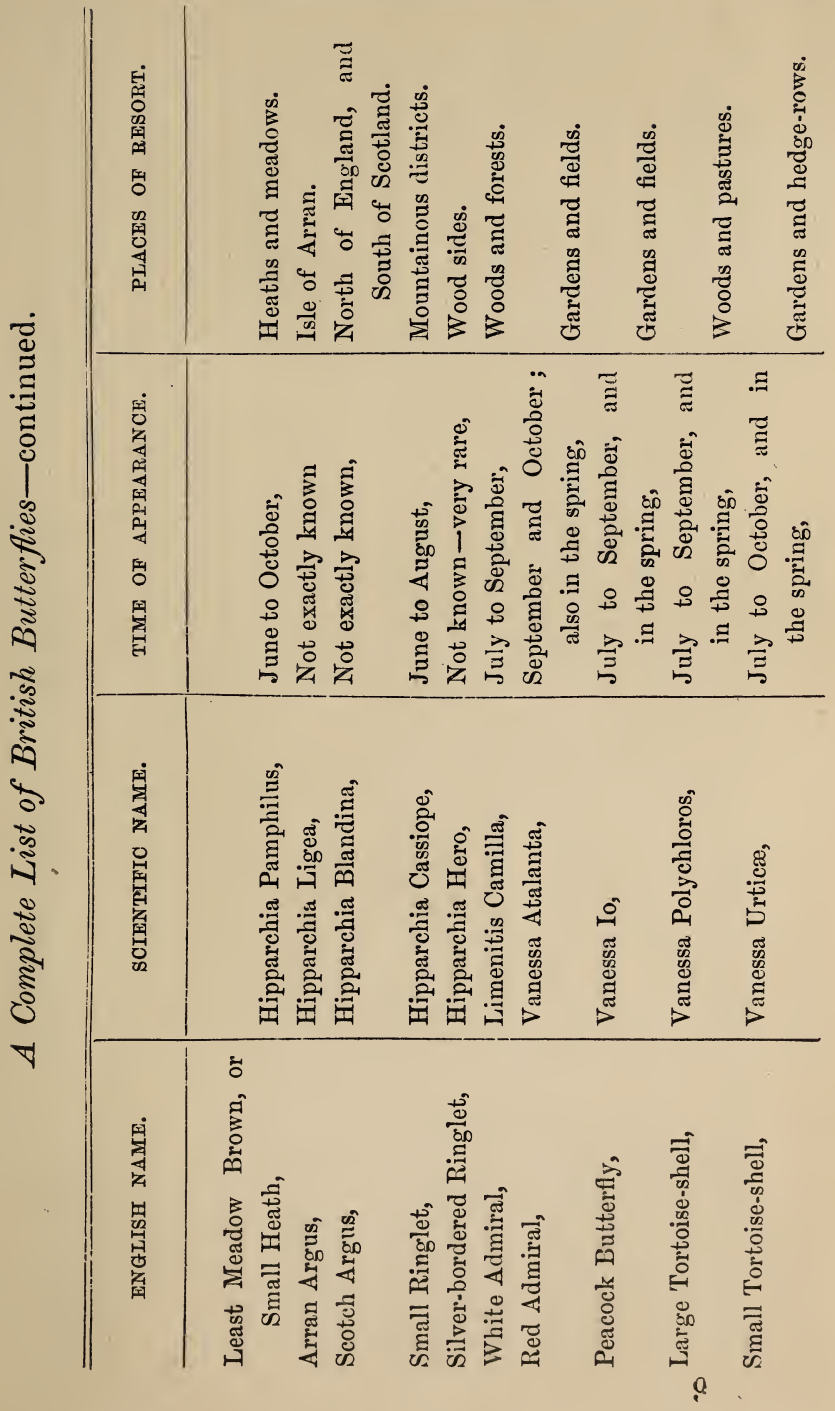


Beautifnl Butterflies.

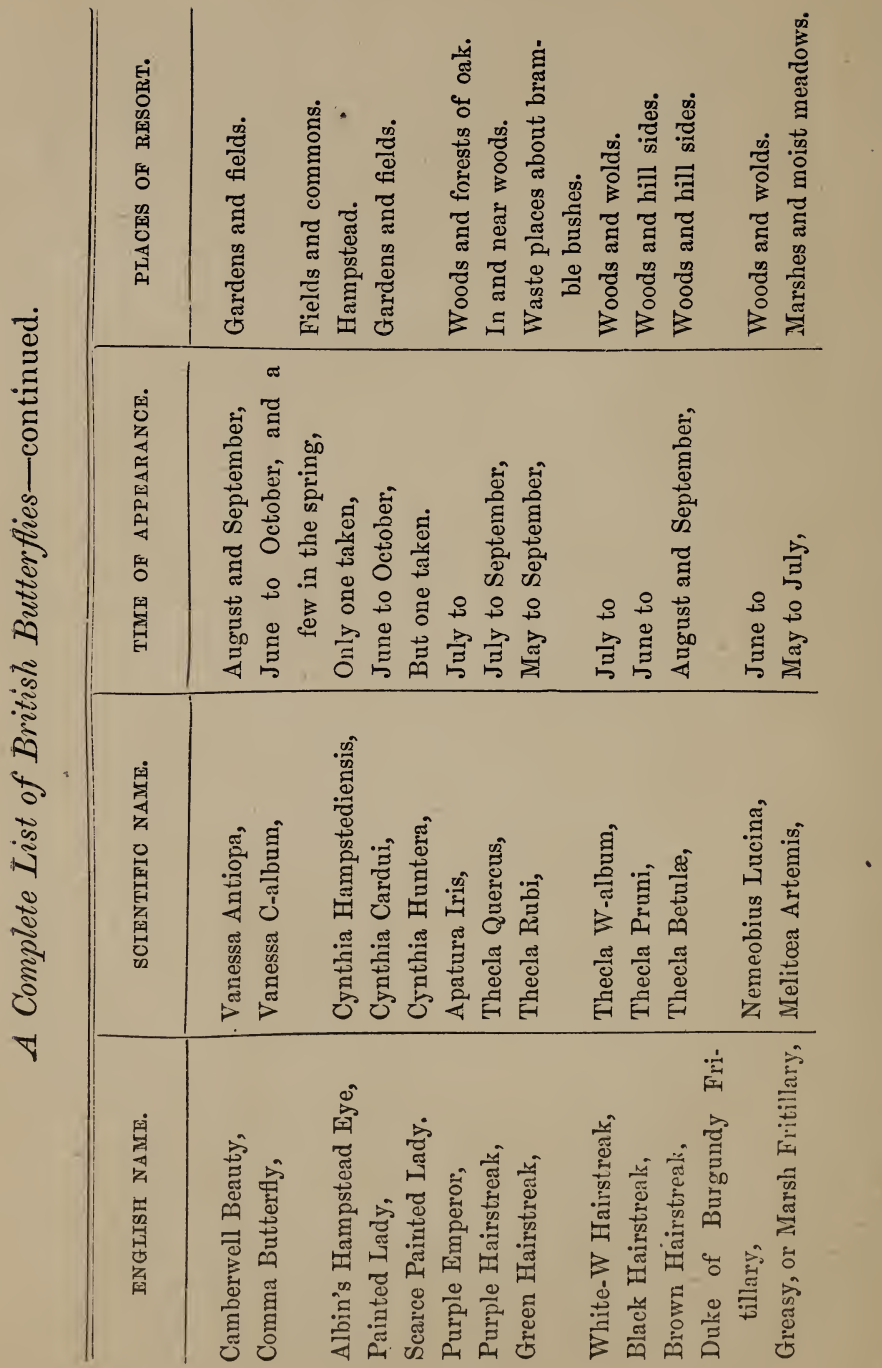


Beautiful Butterflies.

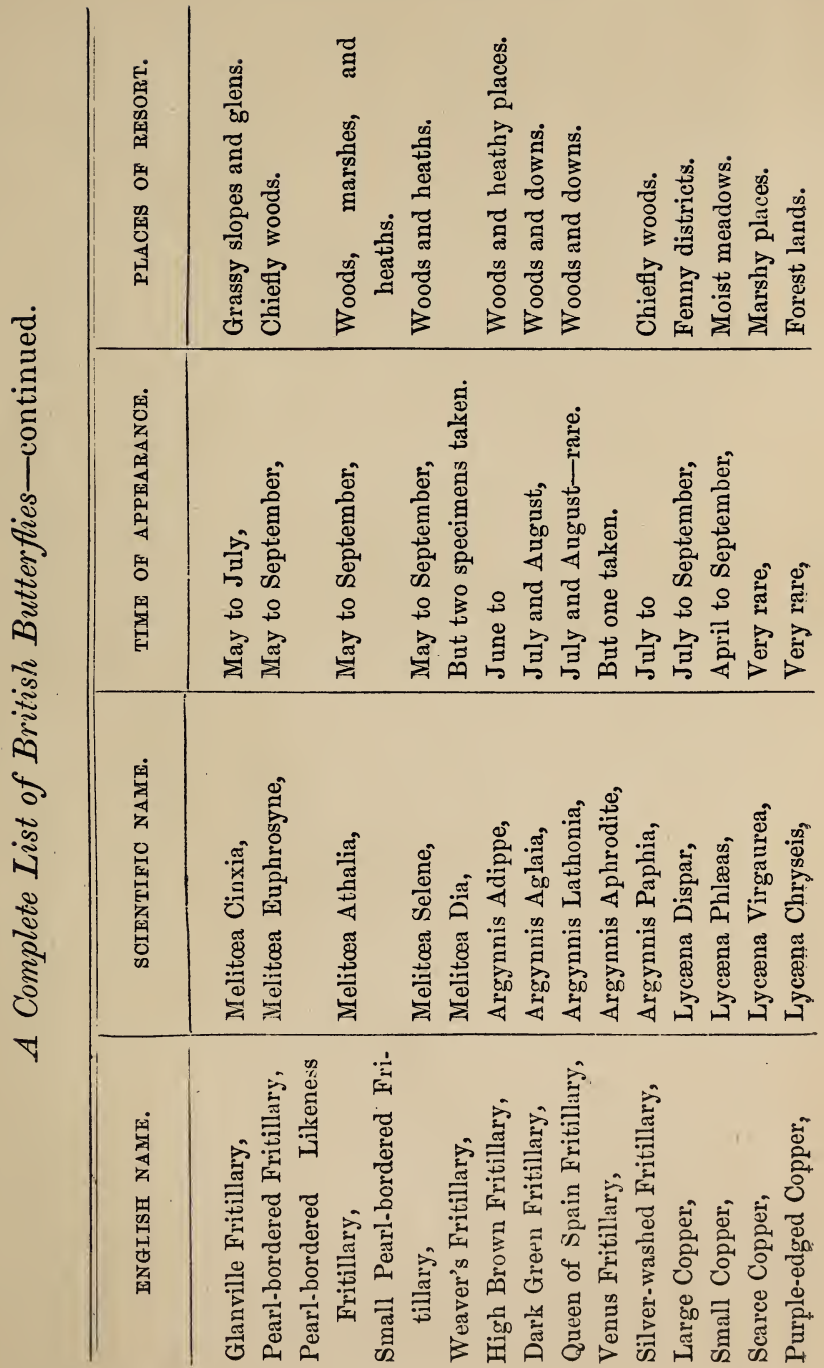




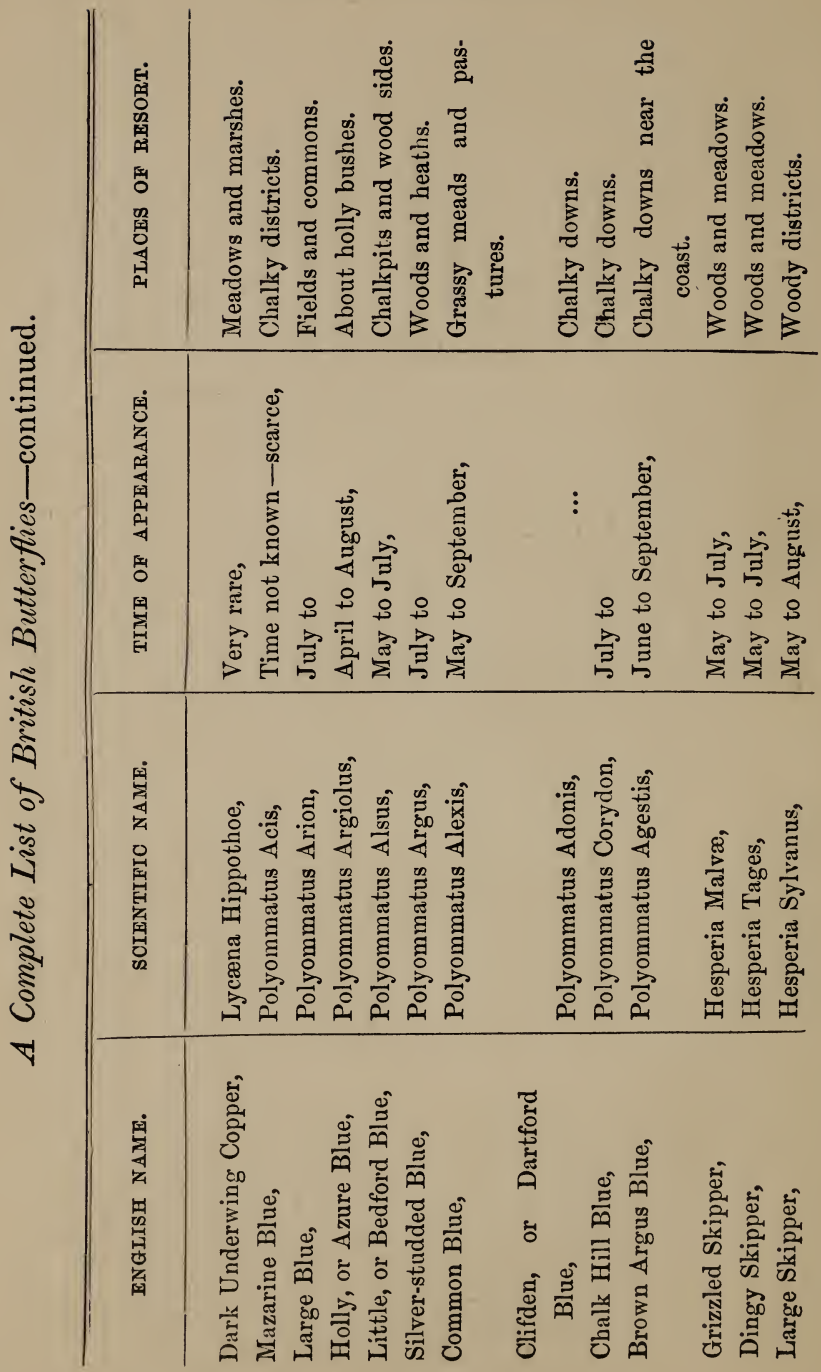




\section{Beautiful Butterfies.}

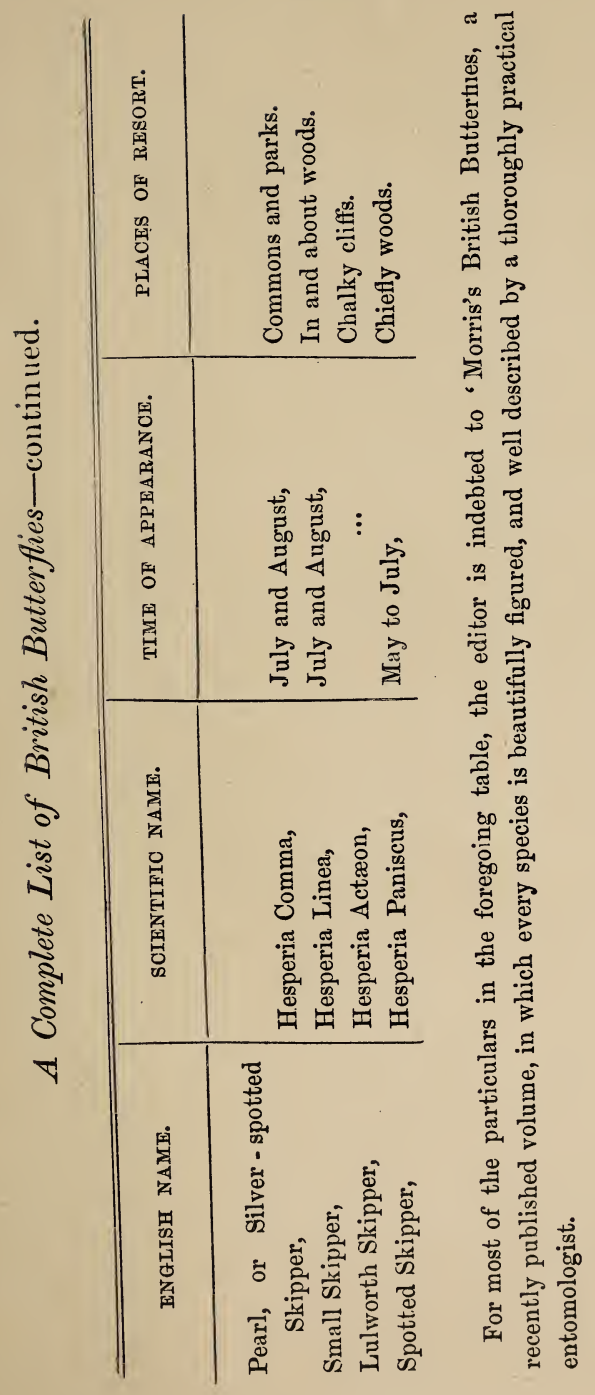





\section{INDEX OF SPECIES}

\section{FIGURED AND DESCRIBED IN THIS VOLUME.}

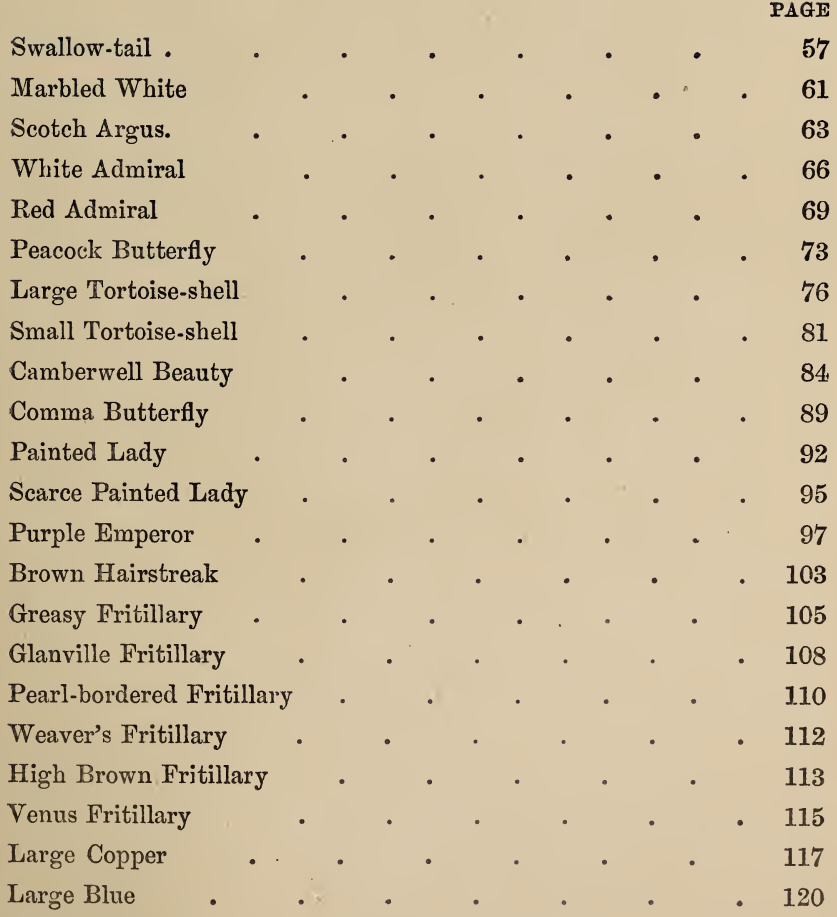



Crown 8vo, elegantly bound, cloth gilt, Illustrated with 8 full-page colourech Plates and numerous Wood Engravings, price 3s. 6 d.

\section{COUNTRY WALKS \\ OF A NATURALIST}

\section{WITH HIS CHILDREN.}

By the Rev. W. HOUGHTON, M.A., F.I.S.

"A fresher, pleasanter, or more profitable book than this has rarely issued from the press."-Art Journal.

"Contrives to furnish a large amount of interesting natural history in brief compass and in a picturesque and engaging manner."-Pall Mall Gazette.

"It is wonderful what a very large amount of most instructive matter connected with the animal and plant world the writer has condensed into a small compass."-Land and Water.

"This pretty little volume forms one of the best little books on popular Natural History, and is admirably adapted as a present to the young."Birmingham Daily Journal.

GROOMBRIDGE \& SONS, 5, Paternoster Row, London.

Crown 8vo, elegantly bound, cloth gilt, Illustrated with 8 beautifully colourecls full-page Plates and numerous Wood Engravings, price 3s. 6d.

\section{SEA-SIDE WALKS \\ OF A NATURALIST}

WITH HIS CHILDREN.

By the Rev. W. HOUGHTON, M.A., F L.\$.

"The wonders of the sea-shore are detailed in an easy, pleasant, and lucid style."-Examiner.

"The book is very attractive, and its usefulness is enhanced by its many careful illustrations."-Daily Telegrap.

"Families visiting the sca-side should provide themselves with this convenient and instructive work." - The Queen.

"It is pleasingly written, and the scientific information is correct and" well selected."-Athenceum.

GR0OMBRIDGE \& SONS, 5, Paternoster Row, London. 
Foolscap 8vo, cloth gilt, Illustrated with 8 full-page Wood Engravings, price 2s. 6d.

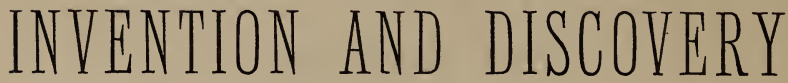

A COLLECTION

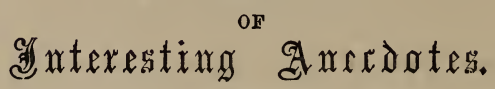

BY

\section{RALPH AND CHANDOS TEMPLE.}

"Has a point and objoct, and a good one-nicely worked out." - Saturday Review.

"We can recommend this book as a Christmas present, and one which has given us no small pleasure."-Literary Churchman.

"Exceedingly well-timed. A volume which should be added to every working-man's club in England."-Notes and Queries.

"Exhibits a conscientious regard for accuracy."-Athenceum.

"The tendency is to instil the principle of self-help and the advantage of earnest purpose."-Bell's Mlessenger.

Foolscap 8vo, cloth gilt, Illustrated with 8 full-page Wood Engravings, price $2 s .6 d$.

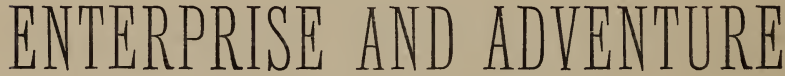

A COLLECTION

OF

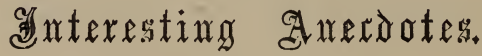

\section{BY \\ RALPH AND CHANDOS TEMPLE.}

"Very handsomely got up. The "Temple Anecdotes' will be one of the most popular of Christmas books."-Standard.

"A sensible, well-written book."-Globe.

"We know of no work which will make a more acceptable present than this extremely handsome and really useful book."-Era.

"As a present for boys, nothing can be better."-Daily News.

"The anecdotes are told with a clearness and simplicity that cannot fail to give pleasure." - Spectator. 
Crown 8vo, elegantly bound, cloth gilt, Illustrated with 8 beautifully coloured full-page Plates and 90 Wood Engravings, price 3s. 6 d.

\section{FIELD FLOWERS}

A HANDY BOOK

FOR

\section{THE RAMBLING BOTANIST,}

SUGGESTING

WHAT to LOOK tOR AND WHERE to GO IN THE OUT-DOOR STUDY OP BRITISH PLANTS.

BY SHIRLEY HIBBERD, F.R.H.S.

"It will serve as an excellent introduction to the practical study of wild flowers."-The Queen.

"We cannot praise too highly the illustrations which crowd the pages of this handbook; the coloured plates are especially attractive, and serve to bring before us very distinctly the most prominent flowers of the field, the heaths, and the hedgerows." -Examiner.

GROOMBRIDGE \& SONS, 5, Paternoster Row, London.

Crown 8vo, elegantly bound, cloth gilt, illustrated with 8 beautifully coloured Plates and 40 Wood Engravings, price 3s. $6 \mathrm{~d}$.

\section{THE FERN GARDEN}

HOW TO MAKE, KEEP, AND ENJOY IT OR,

FERN CULTURE MADE EASY.

DิY SHIRLEY HIBBERD, F.R.H.S,

CONTENTS.

Ferns in Generat

Fern Collecting

HOW TO FORM AN OUTDOOR Fernery

Cultivation of Rock Ferns

Cultivation of Marsh Ferns

Feris in Pots

The Fern Hodse

The Fernery at thi Fireside
Management of Fern Castes The Art of Multiplying Frans British Ferns

Cultivation of Greenhouse Stove Ferns

Select Greenhouse Fernis

Select Stove Ferns

Tree Ferns

FERN ALIIES

GROOMBRIDGE \& SONS, 5, Paternoster Row, London. 
Crown 8vo, elegantly bound, gilt edges, illustrated with Twelve beautifully coloured Engravings, price 3s. 6d., post free for forty-two stamps.

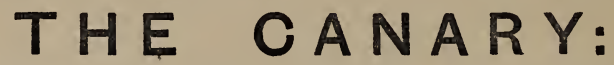

ITS VARIETIES, MANAGEMENT, AND BREEDING. With Portraits of the Author's own Birds. BY THE REv. FRANCIS SMITH.

Contains descriptions of all the Different Varieties of this popular Household Favourite, illustrated with Coloured Portraits of Birds in the possession of the Author. With this book every care has been taken to produce the most complete Manual ; while the Illustrations, general appearance of the volume, and low price at which it is issued, will render it the most popular work on the subject.

CONTENTS.

A PLEA FOR THE CANARY ORIGIN OF OUR OWN CANARIA THE WILD CANARY

OUR LIZARDS

OUR YORKSHIRE SPANGLES

OUR NORWICH YELLOWS

OUR LONDON FANCY BIRDS

OUR BELGIANS

OUR GREEN BIRDS
OUR CINNAMONS

OUR TURNCRESTS

THE DOMINIE \& THE GERMANS

PREPARATIONS FOR BREEDING

NESTS BOXES AND NESTS

OUR FIRST BIRDS

OUR MISFORTUNES

OUR INFIRMARY

ON CAGES

\section{OPINIONS OF THE PRESS.}

"To the reverend gentleman who gives us this book we owe much; it is so admirably done as to be thoroughly perfect as far as the subject goes. He tells us everything about the canary, and in the pleasantest manner, enlivening his story with many anecdotes. Years of thought and study, and familiarity with his subject in all its bearings, have enabled him to tell us everything needful to be known by those who keep the bird-one or many : how best to be its friend and its doctor; how to improve without impairing nature; how, in a word, the extremest amount of enjoyment may be derived from the cultivation of those delicious little inmates of our homes. The book is a delightful book; it may give pleasure to those who do not keep the birds; but to those who do it will be indispensable."-Art Journal.

"A tasteful little book, written evidently by an enthusiast in the study of the beautiful and innocent creatures whose habits he describes. It is likely to make the canary a greater favourite than ever."-Morning Star.

"A large amount of pleasure combined with much curious information may be easily enjoyed by families or young folks who choose to follow Mr. Smith's directions. The bonk is written in a pleasing style, and will take its place as a popular manual and an ornament for the drawing-room table."-The Student.

"The style in which the author details the various incidents connected with his little pets is so pleasant and so alluring, that really one feels inclined on laying down the book to rush out forthwith to the nearest dealer, and without delay secure the necessary material for the formation of an aviary."-City Press.

"This volume contains matter valuable to all who are interested in its subject; while to those who have never paid attention to the canary the work can hardly fail to open up a source of attraction. The reverend author is an enthusiastic lover of the bird, and the result of his experience should find favour with all who share his enthusiasm."-Glasgow Herald.

London: GROOMBRIDGE \& SONS, 5, Paternoster Row. 


\title{
SHILLING GIFT BOOKS FOR YOUNG PEOPLE.
}

Each Book sent Post Free for 12 Stamps.

\section{THE CAPTIVE'S DAUGHTER; AND OTHER STORIES.}

\author{
BY W. HEARD HILLYARD.
}

Illustrated with 15 Wood Engravings. Foolscap 8vo, cloth gilt, 18 .

"If one were asked to select a series of stories most suitable for presents to shildren, and affording real pleasure in their perusal to 'children of a larger Browth,' very few would hesitate to name this series as the very first and best of the class." - Coventry Herald.

\section{THE ORPHANS OF ELFHOLM; AND OTHER STORIES.}

BY FRANCES BROWNE.

Illustrated with 15 Wood Engravings. Foolscap 8vo, cloth gilt, 18.

" $\mathbf{A}$ book to be prized by the young, for its several tales are well written and sull of touching interest."-City Press.

\section{WHEN WE WERE YOUNG; AND OTHER STORIES.}

BY THE AUTHOR OF "A TRAP TO CATCH A SUNBEAM."

Illustrated with 15 Wood Engravings. Foolscap 8vo, cloth gilt, 18.

"The precept of moral courage which it inculcates, coupled with its excellent cone throughout, stamps it at once as being of the right sort."-English Ohurchman.

\section{NOT CLEVER; AND OTHER STORIES.}

BY FRANCES M. WILBRAHAM.

Illustrated with 15 Wood Engravings. Foolscap 8vo, cloth gilt, 1s.

"Pare in tone, full of interest, well got up, and cheap."-Hereford Times.

\section{DEAR CHARLOTTE'S BOYS; AND OTHER STORIES.}

BY EMILY TAYLOR.

Illustrated with 15 Wood Engravings. Foolscap 8vo, cloth gilt, 18.

"We are glad to receive a volume of these pretty stories. There is something sefreshing in them, scarcely to be found in any other publication."-City Press.

\section{THE STORY OF NELSON; AND OTHER STORIES.}

BY W. H. G. KINGSTON.

Illustrated with 15 Wood Engravings. Foolscap 8vo, cloth gilt, 18.

"Mr. Kingston, with great skill, brings out the stirring events of the great Admiral's life from the lips of an old Greenwich pensioner. The story is told with all the enthusiasm of a true 'Salt,' and has the further merit of capital descrip. tive writing."-Plymouth Journal. 


\title{
SHILLING GIFT BOOKS FOR YOUNG PEOPLE。
}

Each Book sent Post Free for 12 Stamps.

\section{BLIND URSULA ; AND OTHER STORIES.}

BY MRS. WEBB.

Illustrated with 15 Wood Engravings. Foolscap 8vo, cloth gilt, 18.

"A domestic tale of humble life, which will well repay perusal. There is an excellent tone, moral and religious, throughout the narrative."-Leeds Intelligencer.

\section{SEA-SHELL ISLAND; AND OTHER STORIES.}

BY G. E. SARGENT.

Illustrated with 15 Wood Engravings. Foolscap 8vo, cloth gilt, 1s.

"An exceeding pretty story." - Somersetshire County Herald.

\section{WHICH WAS THE BRAVEST P AND OTHER STORIES.}

\author{
BY L. A. HALL.
}

Illustrated with 15 Wood Engravings. Foolscap 8vo, cloth gilt, 1s.

"A tale of the Christmas holidays on the banks of the Shannon, intended to show, by the conduct of a party of young people, that rashness and disobedience are no proofs of courage. It should be widely spread, for the spirit of the little book is excellent. The engravings are appropriate and pleasing." -Plymouth Journal.

\section{THE CLOCKMAKER OF LYONS; AND OTHER STORIES. \\ BY E. M. PIPER.}

Illustrated with 15 Wood Engravings. Foolscap 8vo, cloth gilt, 1s.

"An interesting tale, forming one of Messrs. Groombridge's Series of Gifs Books, and by no means the worst of the series."-Cheltenham Journal.

\section{THE ANGEL UNAWARES; AND OTHER STORIES.}

BY MARY HOWITT.

Illustrated with 15 Wood Engravings, Foolscap 8vo, cloth gilt, 18.

"A pretty story of kindness rewarded by success. The principal actors are children, and the teaching of the story, while it is full of point for older learners, is adapted especially to the capacity of youth."-Plymouth and Devonport Journal.

\section{HISTORICAL DRAMAS.}

BY THE AUTHOR OF “THE HEIR OF REDOLFFFE." Illustrated with 15 Wood Engravings. Foolscap 8vo, cloth gilt, 1s.

"Combines amusement with instruction in a way that must please the rising generation."-Renfrewshire Independent. 
Each Book sent Post Free for 12 Stamps.

\title{
LOST IN THE WOOD; AND OTHER STORIES.
}

BY MRS. GILCHRIST.

Illustrated with 15 Wood Engravings. Foolscap 8vo, cloth gilt, 1s.

"Perfectly healthy in tone, and highly interesting, these tales are indeed most suitable for family reading."-Gloucester Mercury.

\section{RAINBOW'S REST; AND OTHER STORIES.}

BY THOMAS HOOD.

Illustrated with 15 Wood Engravings. Foolscap 8vo, cloth gilt, 1 s.

"These are excellent stories for children, and nicely got up and illustrated." Paisley Herald.

\section{*A COMPLETE SET OF THE TWENTY VOLUMES, VIZ. :-}

\author{
UNION JACK. By Mrs. S. C. HaLI. \\ TOWN OF TOYS. By SARA WOOD.
}

NO MAN'S LAND. By T. MILLER.

SEA SPLEENWORT. By Author of "The Heir of Redclyffe."

LOTTIE'S HALF-SOVEREIGN. By Mrs. RUSSELI Gray.

THE SHEPHERD LORD. By JULIA CORNER.

THE CAPTIVE'S DAUGHTER. By W. Heard Hillyard.

THE ORPHANS OF ELFHOLM. By Frances Browne.

WHEN WE WERE YOUNG. By Author of "A Trap to Catch a Sunbeam."

NOT CLEVER. By Frances M. Wilbraham.

DEAR CHARLOTTE'S BOYS. By EMILY TAYLOR.

STORY OF NELSON. By W. H. G. KINGSTON.

BLIND URSULA. By Mrs. WebB.

SEA-SHELL ISLAND. By G. E. Sarghet.

WHICH WAS THE BRAVEST? By L. A. HALL.

THE CLOCKMAKER OF LYONS. By E. M. PiPer.

THE ANGEL UNAWARES. By MaRY HowitT.

HISTORICAL DRAMAS. By Author of "The Heir of Redclyffe." LOST IN THE WOOD. By Mrs. GILCHRIST.

RAINBOW'S REST. By Thomas Hood.

Enclosed in a Box, 20s.

"We have read most of them with great care, for we are very watchful over books for the young, and can assure our readers they are well worth a mother's attention. They vary in interest and in moral value, but all of them are calcu. lated both to amuse and instruct. Some convey valuable historical information, others lessons in natural history, and most of them convey a healthy moral in. fluence. All are subservient to religion as well as morals, but they are not tinctured with any ism, nor do they inculcate any peculiar tenets."-British Mothero' Journal. 
Crown 8vo, elegantly bound, cloth gilt, Illustrated with 8 beautifully coloured full-page Plates and numerous Wood Engravings, price 3s. $6 \mathrm{~d}$.

\section{THE MICROSCOPE}

A Popular Description of some of the most Beautiful and Instructive Objects for Exhibition.

With Directions for the Arrangement of the Instruments and the Collection and Mounting of Objects.

BY THF HoN. MRS. WARD.

“This elegant book deserves at our hands especial commendation for many reasons. There is no book that we know of that we would more willingly place in the hands of a beginner to create an interest in the science of Microscopy. The Illustrations are beautiful, coloured to represent nature, and all original. To our readers we cannot give better advice than to become purchasers of the book-they will not regret the outlay." -Elecsrician.

GROOMBRIDGE \& SONS, 5, Paternoster Row, London.

Orown 8vo, elegantıy bound, cloth gilt, Tlustrated with 12 beautifully coloured full-page Plates and numerous Wood Engravings, price 3s. 6d.

\section{THE TELESCOPE}

A FAMILIAR SKETOH

Combining a Speciat Notloy of Objects coming within thr Raner CF a SMall Telescopi

With a Detail af the most Interesting Discoveries which have been made with the assistance of powerful Telescopes, concerning the Phenomena of the Heavenly Bodies.

BY the Hor. Mrs. WAKd.

" It is with pleasure that we direct the reader's attention to a little gem dately published by the Hon. Mrs. WARD. One of the most admirable little works on one of the most sublime subjects that has been given to the world. The main design of the book is to show how much may be done in astronomy with ordinary powers and instruments. We have no hesitation in waying that we never saw a work of the kind that is so perfect. The illusarations are admirable, und are all original."-Western Daily Press. 


\section{GARDEN AND GREENHOUSE.}

Valuable Monthly Work of Reference, WITH BEAUTIFULLY COLOURED PLATES,

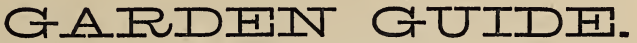
EDITED BY SHIRLEY HIBBERD, ESQ., F.R.H.S.

PUBLISHED MONTHLY, PRICE SIXPENCE. ANNUAL SUBSCRIPTION, SIX SHILLINGS. A Specimen Number sent post free for Seven Stamps.

"The coloured picture is so ridiculously beyond the price of the magazine that we have nothing more to say of it. Mr. Shirley Hibberd is a celebrity in the floral world; but with all his ability, we cannot imagine where he discovered the secret of giving the public a magazine worth half-a-crown for sixpence-and making the thing pay."-Worcester Herald.

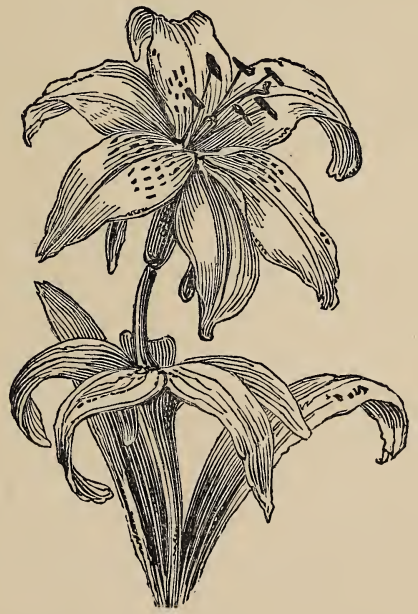

GROOMBRIDGE \& SONS,

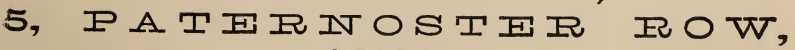

\section{LONDON.}

And all Booksellers. 


\section{GIFT BOOKS FOR YOUNG PEOPLE}

At One Shilling and Sixpence each.

OSCAR: A TALE OF NORWAY.

AND OTHER STORIES.

Containing Osoar : a Tale of Norway; Home at the Haven; The Foundling of the Wreck.

\section{THE CHILDREN AND THE SAGE.}

AND OTHER STORIES.

Containing The Children aNd the SAge : a Story of Galileo; Thr

Seerer aNd the Finder : a Story of Columbus; The Story

of Wellington.

ALFRED THE GREAT.

AND OTHER STORIES FROM HISTORY.

Containing Alfred the Great; The King and the Bondmen; The Crusaders.

ROUND THE WORLD.

AND OTHER STORIES.

Containing Round the World ; The Prophet and the Lost City ; The ShIP and the Island.

MOFFAT, THE MISSIONARY.

AND OTHER STORIES.

Containing Moffat, the Missionary ; Haloyon Days ; The REWARDS OF INDUSTRY.

LOUIS DUVAL.

AND OTHER STORIES.

Containing Louis Duval : a Story of the French Revolution; The Sea Kings ; The Young Emigran's.

The following Critical Opinions have appeared on the above Books:

"These stories are all distinguished by high feeling and sensible teaching." Morning Post.

"This is a very meritorious series."-Standard.

"May be safely recommended to all who are looking out for cheap, pleasant and sensible story books. Their general tone is excellent, and the stories, which embrace many different subjects, are related in a lively and entertaining style." - Manchester Examiner.

"Each and all of them, are well worthy the attention of parents anxious to find a presentable book, which shall elevate as well as entertain the minds of the reader."-Croydon Chronicle.

"These works are well printed, carefully illustrated, and bound in a very handsome and attractive manner; all likely to interest, at the same time to instruct young persons."-Scotsman.

"Very pleasant volumes, all prettily illustrated."-Graphic.

"This is a series of books tastefully bound, finely illustrated, and written in the free, simple, and enthusiastic style, which captivates juvenile minds."-Glasgow Daily Herald.

GROOMBRIDGE \& SONS, 5, Paternoster Row, London. 


\section{ELEGANT GIFT BOOKS}

ON

NATURAI FISTORY.

Demy 8vo., cloth, gilt edges, with beautifully coloured Illustrations, from Drawings by eminent artists, price 5s. (post free for 60 stamps.)

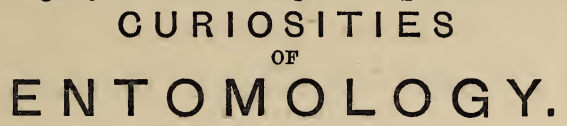

A Collection of highly interesting Essays upon the peculiarities of Insects and Insect Life.

CONTAINING

Bees and their Counterfeits.

British and Foreign Beetles.

Micro-Lepidoptera, or Leaf-miners.

Coleophora, or Tent Makers.

Ephemera, or May Fly.

Mimetic Analogy.

Insect Disguises.

Oak Feeding Silkworm of China.

Insects' Eggs.

The Microscope.

Demy 8vo., cloth, gilt edges, with beautifully coloured Illustrations, from Drawings by eminent artists, price $5 \mathrm{~s}$. (post free for $60 \mathrm{stamps}$.)

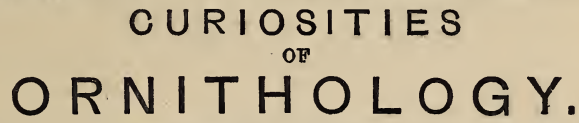

A Collection of highly interesting Essays upon the peculiarities of Birds and Bird Life.

CONTAINING

The Pinnated or Prairie Grouse.

Birds of Paradise.

Horned Pheasants or Tragopans.

The Blue Checked Barbet.

The Hornbills.
The King Penguin.

The Bell Birds of America.

The Turacoes of Africa.

The Owl-Parrot of New Zealand.

The following Critical Opinions have appeared on these two Books:

"The illustrations to these are beyond all praise, and would alone make the books valuable as gift books, to say nothing of the popular character of the information contained in them."-Public Opinion.

"Contain exquisitely coloured plates, and the accompanying text is all that can be desired in explanation of them."-Gardeners' Magazine.

"Admirably illustrated, while the descriptions are so free from technical language, that the most unlearned can comprehend them."-John Bull.

"The illustrations are admirable, and to a naturalist one of the most desirable possessions."-Sunday Times.

"Will prove of real value to students."-Standard.

"No gift book could be more appropriate, nor we should say more acceptable to one fond of Natural History."-Scotsman.

"Elaborate contributions to the discoveries of Science."-Bell's Weekly Messenger.

GROOMBRIDGE $\bar{d}$ SONS, 5, Paternoster Row, London. 
Crown 8vo., cloth, gilt edges, Illustrated with Coloured plates and numerous Wood Engravings, price 5s. (post free for 60 stamps.)

\section{THE AMATEURS' \\ FLOWER GARDEN}

A Practical Guide to the Management of the Garden and the Cultivation of Popular Flowers.

BY SHIRLE Y H I B E R D, F.R.H.S.

Author of "Rustic Adornments for Homes of Taste," "The Rose Book," " Profitable Gardening," "The Fern Garden," "Field Flowers," "The Town Garden," etc., etc.

CONTENTS:

Chapter I. FormingtheFlower Garden | Chapter XI. The American Garden.

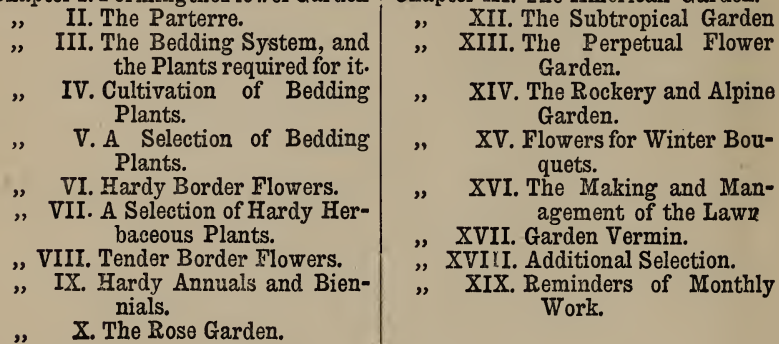

The following Critical Notices have appeared of this Book:

"It is practical throughout; the book will be useful and acceptable."Gardener's Chronicle.

"For any one with tastes and opportunities for gardening, it may be recommended as of more enduring value than books of greater interest for the superficial reader."-Standard.

"An elegant and charmingly illustrated volume. It is intended for those who possess what may be called 'homely' gardens as distinguished from great and grand gardens ; and it is wonderful to find under the author's guidance, how much may be made of ever so small a piece of garden ground."-Leeds Mercury.

"Ladies fond of gardening will find an immense amount of useful information in this handy and reliable work."-Treasury of Literature.

"No amateur should be without a copy. In fact he had better have two; one for use, and one for the drawing-room table."-Fun.

"No amateur can be at a loss, whatever exigency may arise, with Mr. Hibberd's book at hand."-Scotsman.

"We have here one of the most useful works to the amateur that has ever been published."-Sunday Times.

"“THE AMATEUR's FLOWER GARDEN" will be hailed with delight by the multitudes who find intense delight in their flower gardens. The beautiful iliustrations enhance immensely the value of the book."-John Bull.

"A first-rate present for all who, of any age or eithor sex, take pleasure in gardening."-Daily News.

"A charming gift-book for a lady, full of sound practical information, and liberally illustrated with beautifully coloured plates." -Lady's Own Paper. 


\section{A IN IN A IIS I}

This elegant edition, large crown $8 \mathrm{ro}$, is handsomely bound in cloth, gils enges, suitable for presentation, and Illustrated by the leading artists of the day.

In One Volume, large crown 8vo, Illustrated, price 5s.

\section{SELF AND SELF-SACRIFICE NELLY'S STORY. \\ BY ANNA LISLE.}

"A very beautiful story, with characters well drawn, scenery vividly described, and interest admirably sustained. The tendency of the volume is not only unexceptionable, bat excellent in a Christian point of view. We have seldom seen a book in which the best and highest aim is so manifest without the attractiveness of the tale being at all lessened by the embodiment of religious principles." -Eclectic Revievo.

"The story is so delightful, and the whole spirit of the book so pare, that it compels our admiration." - Daily Nevs.

"Since "Currer Bell" we have read nothing more genuine, nor more touching. "Nelly's Story' has power to carry the reader right through with it, and can hardly fail to impress a moral of inestimable importance." - Carlisle Journal.

"Admirably written, pervaded throughout by fine, correct, and wholesome sentiments." - Morning Post.

sc Its excellent moral tone, and keen observation, are sure to render the book widely popular." -John Bull.

" "Nelly's Story' is a good one. It is one of the best we have read for a long time." - Bucks Advertiser.

"Abounding in interest. We can hardly conceive a more suitable gift-book." Lady's Newspaper.

"Will be welcomed, read, and talked about."-Gentleman's Magazine.

" 'Nelly's Story" is told in such a good and pleasant way, and withal is so useful snd world-like, that we trust it may bring to its authoress the fame that she is well able to oupport." - Tait's Magazine.

"We recognize and proclaim in the authoress of this thrilling tale a quality beyond mere ability-genius of a very high order. We claim for Anna Lisle a place amongst the most distinguished writers of her age. The story is a brilliant effort of refined anc. sanctified imagination throughout, quite as fascinating as anything in the way of atory, whether told by Scott, Stowe, Dickens, or Currer Bell."-Sentinel.

In One Volume, large crown 8vo, Illustrated, price 5s.

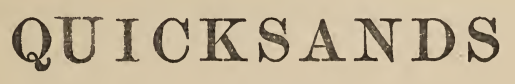

A TALE.

\section{BY ANNA LISLE.}

"It is a thoronghly woman's book. We can fairly say that we have seldom met wits sraver or more striking warning against the consequences of over eagerness abord orldly position and advantages, more forcibly and, at the same time, gracefully cor. yed." -Literary Gazette.

"Contrins a great deal of quiet and powerfal writing. Marty, the maid of Mrs. ey, might pass for a creation of Dickens. The moral of 'Quicksands ' is at once hensive and striking." - Weekly Mail. 
Crown 8vo, cloth, gilt edges, Illustrated with Coloured Plates of all the varieties. Price 4 s. (post free for 48 stamps).

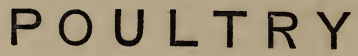

A PRACTICAL GUIDE

To the Choice, Breeding, Rearing, and Management of all descriptions of

\section{FOWLS, TURKEYS, GUINEA FOWLS, DUCKS, AND GEESE, FOR PROFIT AND EXHIBITION.}

With accurate and beautifully Coloured Plates, illustrating all the different varieties.

B Y H UGY PIPER.

Author of "Pigeons ; their Varieties, Management, Breeding, and Diseases."

\section{CONTENTS :}

CHAP. I. Introduction.-Neglect of Poultry-breeding-Profit of Poultrykeeping-Value to the Farmer-Poultry Shows-Cottage Poultry. CHAP. II. The Fowl-House. - Size of the House-Brick and Wood-Cheap Houses--The Roof -Ventilation-Light-Warmth - The Flooring - Perches-Moveable FrameRoosts for Cochin-Chinas and Brahmah-Pootras-Nests for Laying-Cleanliness -Fowls' Dung - Doors and Entrance-holes - Lime-washing - FumigatingRaising Chickens under Glass. CHAP. III. The Fowl-Yard.-Soil-Situation-Covered Run-Pulverised Earth for Deodorising-Diet for Confined Fowls-Height of Wall, \&c.-Preventing Fowls from Flying-The Dust-heapMaterial for Shells-Gravel-The Gizzard-The Grass Run. CHAP. IV. Food.-Table of Relative Constituents and Qualities of Food-Barley-OatsMeal-Refuse Corn-Boiling Grain-Indian Corn or Maize-Buckwheat, Peas, Beans, and Tares-Rice-Hempseed-Linseed-Potatoes-Roots-Soft FoodVariety of Food-Quantity-Mode of Feeding-Number of Meals-Grass and Vegetables-Insects-Worms-Snails and Slugs-Animal Food-Water-Fountains. CHAP. V. Eggs.-Eggs all the Year round-Warmth Essential to Laying-Forcing Eggs-Soft Shells-Shape and Colour of Eggs-The Air-bagPreserving Eggs-Keeping and Choosing Eggs for Setting-Sex of EggsPacking Setting-eggs for Travelling. CHAP. VI. The Sitting Hen.-Evil of Restraining a Hen from sitting-Checking the Desire-A Separate House and Run-Nests for Sitting in-Damping Eggs-Filling for Nests-Choosing their own Nests-Choosing a Hen for Sitting-Number and Age of Eggs-Food and Exercise-Absence from the Nest-Examining the Eggs-Setting two Hens on the same Day-Time of Ihcubation-The "Tapping "Sound-Breaking the Shell-Emerging from the Shell-Assisting the Chicken-Artificial MothersArtificial Ineubation. CHAP. VII. Rearing and Fattening Fowls. The Chicken's first Food-Cooping the Brood-Basket and Wooden Coops-Feeding Chickens-Age for Fattening-Barn-door Fattening--Fattening Houses-Fattening Coops-Food-"Cramming "-Capons and Poulardes-Killing PoultryPlucking and Packing Fowls-Preserving Feathers. CHAP. VIII. Stock, Breeding, and Crossing.-Well-bred Fowls-Choice of Breed-Signs of AgeBreeding in-and-in-Number of Hens to one Cock-Choice of a Cock-To prevent Cocks from Fighting-Choice of a Hen-Improved Breeds-Origin of Breeds-Crossing-Choics of Breeding Stock-Keeping a Breed Pure. CHaP. IX. Poultry Shows.-The First Shows-The first Birmingham Show-Influence of Shows-Exhibition Rules-Hatching for Summer and Winter ShowsWeight-Exhibition Fowls Sitting-Matching Fowls-Imparting Lustre to the Plumage - Washing Fowls-Hampers-Travelling-Treatment on ReturnWashing the Hampers and Linings-Exhibition Points. Technical Terms -Cuaps. X. to XXIII. inclusive. The Different Breeds.-Chap. XXIV. Diseases.

GROOMBRIDGE \& SONS. 5, Paternoster Row, London. 


\section{HOME-MADE WINES. How to Make and Keep} them, with remarks on preparing the fruit, fining, bottling, and storing. By G. Vine. Contains Apple, Apricot, Beer, Bilberry, Blackberry, Cherry, Clary, Cowslip, Currant, Damson, Elderberry, Gooseberry, Ginger, Grape, Greengage, Lemon, Malt, Mixed Fruit, Mulberry, Orange, Parsnip, Raspberry, Rhubarb, Raisin, Sloe, Strawberry, Turnip, Vine Leaf, and Mead.

CARVING MADE EASY; or, Practical Instructions for Diners Out. Illustrated with Engravings of Fish, Flesh, and Fowl, and appropriate instructions, whereby a complete and skilful knowledge of the useful art of Carving may be attained, and the usages of the Dinner Table duly observed. By A. MERRYTHOUght.

3. SINGING IIADE EASIER FOR AMATEURS, explaining the pure Italian Method of Producing and Cultivating the Voice; the Management of the Breath; the best way of Improving the Ear; with much other valuable information equally valuable to Professional Singers and Amateurs.

4. COTTAGE FARMING; or, How to Cultivate from Two to Twenty Acres, including the Management of Cows, Pigs, and Poultry. By Martin Doyle. Contains, On Enclosing a Farm, Land Drainage, Manures, Management of a Two-acre Farm, Cow Keeping, The Dairy, Pig Keeping, Bees and Poultry, Management of a Ten-acre Farm, Flax and Rape, Management of a Farm of Twenty Acres, Farm Buildings, etc.

5. MARKET GARDENING, giving in detail the various methods adopted by Gardeners in growing the Strawberry, Rhubarb, Filberts, Early Potatoes, Asparagus, Sea Kale, Cabbages, Cauliflowers, Celery, Beans, Peas, Brussels Sprouts, Spinach, Radishes, Lettuce, Onions, Carrots, Turnips, Water Cress, etc. By JaMes Cuthil, F.R.H.S.

6. COTTAGE COOKERY. Containing Simple Instructions upon Money, Time, Management of Provisions, Firing, Utensils, Choice of Provisions, Modes of Cooking, Stews, Soups, Broths, Pucdings, Pies, Fat, Pastry, Vegetables, Modes of Dressing Meat, Bread, Cakes, Buns, Salting or Curing Meat, Frugality and Cheap Cookery, Charitable Cookery, Cookery for the Sick and Young Children. By Estuer Coptey.

\%. CLERK'S DICTIONARY OF COMMERCIAL TERMS; containing Explanations of upwards of Three Hundred Terms used in Business and Merchants' Offices. By the Author of "Common Blunders in Speaking and Writing Corrected."

"An indispensable book for all young men enterıng a counting-house for the first time."

8. THE CAT, Its History and Diseases, with IMethod of Administering Medicine. By the Honourable LADy CusT. 
9. ELOCUTION MADE EASY for Clergymen, Public Speakers, and Readers, Lecturers, Actors. Theatrical Amateurs, and all who wish to speak well and effectively in Public or Private. By Charles Hartuey. Contents: Cultivation of the Speaking Voice, Management of the Voice, Pausing, Taking Breath, Pitch, Articulation, Pronunciation, The Aspirate, The Letter R, Emphasis, Tone, Movement, Feeling and Passion, Verse, Scriptural Reading, Stammering and Stuttering, Action, Acting, Reciting, etc.

10. ORATORY MADE EAST. A Guide to the Composition of Speeches. By Charles Hartuey. Contents: Introduction, Power of Art, Various Kinds of Oratory, Prepared Speech, Constructing a Speech, Short Speeches, Command of Language, Reading and Thinking, Style, Hasty Composition, Forming a Style, Copiousness and Conciseness, Diction or Language, Purity and Propriety, Misapplied Words, Monosyllables, Specific Terms, Variety of Language, Too Great Care about Words, Eipithets, Precision, Synonymes, Perspicuity, Long and Short Sentences, Tropes and Figures, Metaphor, Simile, etc.

11. THE GRAMIMATICAL REMEMBRANCWR; or, Aids for correct Speaking, Writing, and Spelling, for Adults. By Charles Hartuey. Contents: Introduction, Neglect of English Grammar, Divisions of Grammar, Parts of Speech, The Article, The Silent H, Nouns, Formation of the Plural, Genders of Nouns, Cases of Nouns, Comparison of Adjectives, Personal Pronouns, Relative Pronouns, Demonstrative Pronouns, Regular and Irregular Verbs, Shall and Will, The Adverb, Misapplication of Words, Division of Words, Capital Letters, Rules for Spelling. Double $l$ and $p$, A Short Syntax, Punctuation, etc.

12. THE CANARY. Its History, Varieties, IRanagement, and Breeding, with Coloured Frontispiece. By RicHARD Avis. Contains, History of the Canary, Varieties of the Canary, Food and General Management, Cages, Breeding, Education of the Young, Mules, Diseases, etc.

13. BIRD PRESERVING and Bird Mounting, and the Preservation of Birds' Eggs, with a Chapter on Bird Catching. By Richard Avis.

14. WINE GUIDE; or, Practical Hints on the Purchase and Management of Foreign Wines, their History, and a complete catalogue of all those in present use, together with remarks upon the treatment of Spirits, Bottled Beer, and Cider. To which is appended Instructions for the Cellar, and other information valuabie to the Consumer as well as the Dealer. By Frederick C. Milts. 





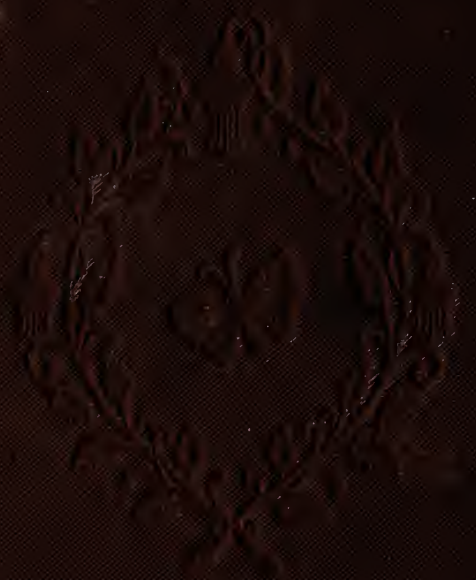

